Prepared in cooperation with the Missouri Department of Transportation

\title{
Bathymetric Surveys at Highway Bridges Crossing the Missouri and Mississippi Rivers near St. Louis, Missouri, 2010
}

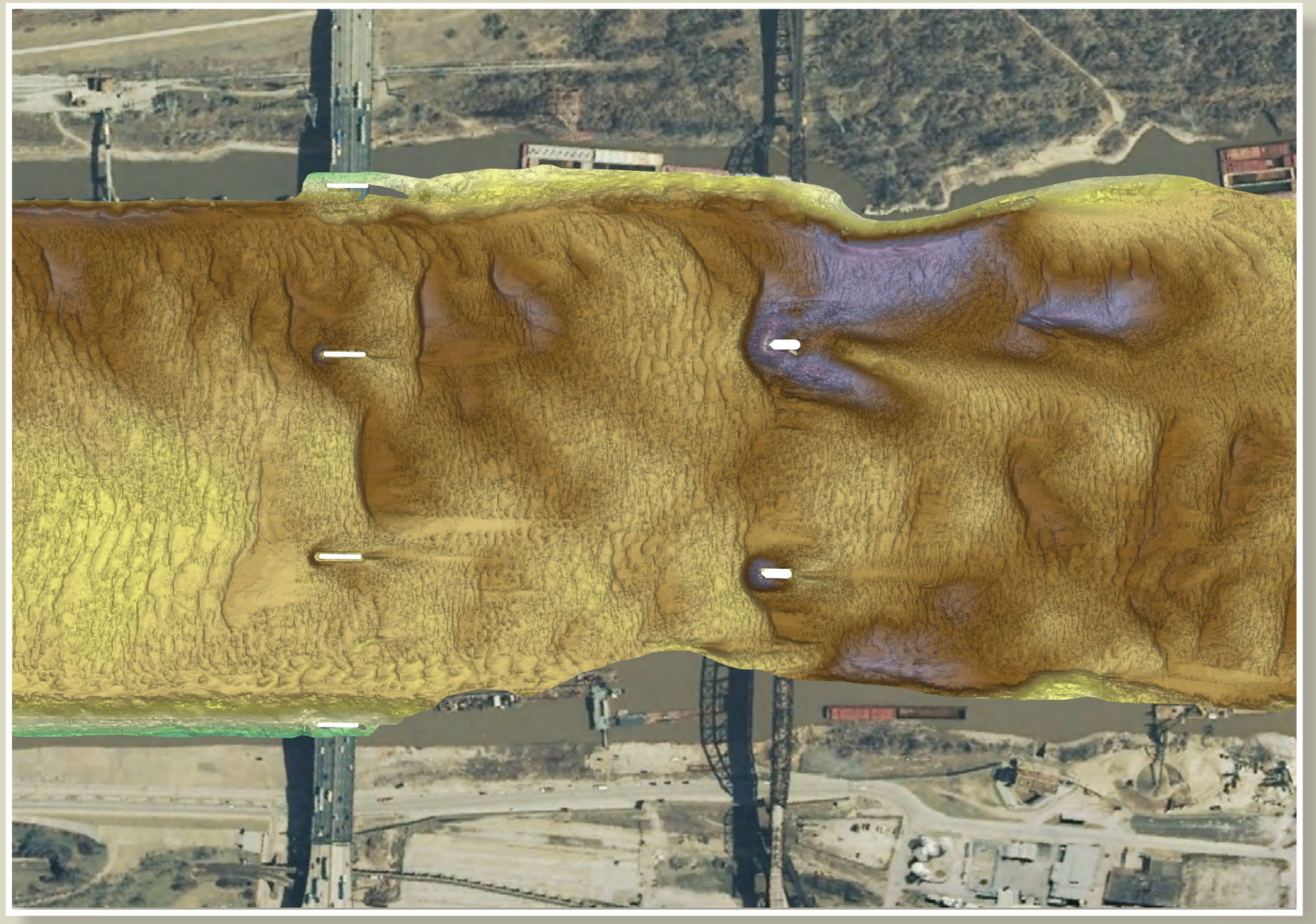

Scientific Investigations Report 2011-5170 
Cover. Bathymetric survey of the Mississippi River channel in the vicinity of structure A1500 on Interstate 55 near St. Louis, Missouri. 


\section{Bathymetric Surveys at Highway Bridges Crossing the Missouri and Mississippi Rivers near St. Louis, Missouri, 2010}

By Richard J. Huizinga

Prepared in cooperation with the Missouri Department of Transportation

Scientific Investigations Report 2011-5170 


\section{U.S. Department of the Interior \\ KEN SALAZAR, Secretary \\ U.S. Geological Survey \\ Marcia K. McNutt, Director}

U.S. Geological Survey, Reston, Virginia: 2011

For more information on the USGS - the Federal source for science about the Earth, its natural and living resources, natural hazards, and the environment, visit http://www.usgs.gov or call 1-888-ASK-USGS.

For an overview of USGS information products, including maps, imagery, and publications, visit http://www.usgs.gov/pubprod

Any use of trade, product, or firm names is for descriptive purposes only and does not imply endorsement by the U.S. Government.

Although this report is in the public domain, permission must be secured from the individual copyright owners to reproduce any copyrighted materials contained within this report.

Suggested citation:

Huizinga, R.J., 2011, Bathymetric surveys at highway bridges crossing the Missouri and Mississippi Rivers near St. Louis, Missouri, 2010: U.S. Geological Survey Scientific Investigations Report 2011-5170, 75 p. 


\section{Contents}

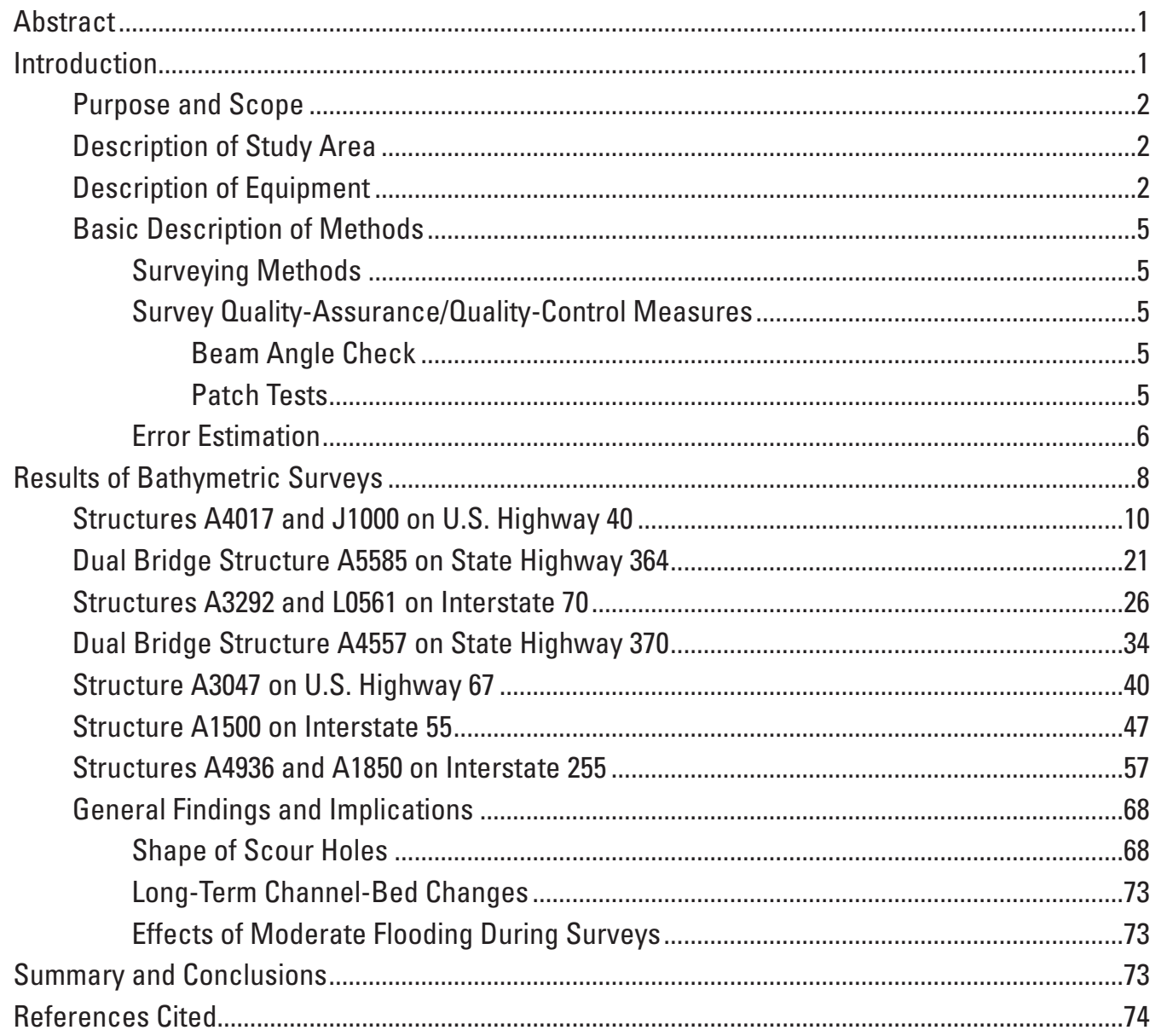




\section{Figures}

1. Map showing location of bridges crossing the Missouri and Mississippi Rivers in the St. Louis, Missouri, metropolitan area ....

2. Diagram showing effects of $A$, timing offset for latency, and angular offsets for, $B$, roll, $C$, pitch, and $D$, yaw on data from a multibeam echo sounder..

3. Aerial photograph showing total propagated error of bathymetric data from the Mississippi River channel in the vicinity of structures A4936 and A1850 on Interstate 255 near St. Louis, Missouri.

4. Aerial photograph showing location of the bathymetric survey area on the Missouri River near structures A4017 and J1000 on U.S. Highway 40 near St. Louis, Missouri .

5. Bathymetric survey of the Missouri River channel in the vicinity of structures A4017 and J1000 on U.S. Highway 40 near St. Louis, Missouri.

6. Bathymetric survey of the Missouri River channel in the vicinity of the left main channel piers of structures A4017 and J1000 on U.S. Highway 40 near St. Louis, Missouri.

7. Diagram showing key features, substructural and superstructural details, and surveyed channel bed of structure A4017 on U.S. Highway 40 over the Missouri River near St. Louis, Missouri.

8. Bathymetric survey of the Missouri River channel in the vicinity of the central main channel piers of structures A4017 and J1000 on U.S. Highway 40 near St. Louis, Missouri

9. Diagram showing key features, substructural and superstructural details, and surveyed channel bed of structure J1000 on U.S. Highway 40 over the Missouri River near St. Louis, Missouri

10. Point cloud visualization of the channel bed and left (north) side of the main channel piers (pier 5) of structures A4017 and J1000 on U.S. Highway 40 over the Missouri River near St. Louis, Missouri.

11. Bathymetric survey of the Missouri River channel in the vicinity of the right main channel piers of structures A4017 and J1000 on U.S. Highway 40 near St. Louis, Missouri

12. Aerial photograph showing location of the bathymetric survey area on the Missouri River near dual bridge structure A5585 on State Highway 364 near St. Louis, Missouri...

13. Bathymetric survey of the Missouri River channel in the vicinity of dual bridge structure A5585 on State Highway 364 near St. Louis, Missouri

14. Bathymetric survey of the Missouri River channel in the vicinity of the main channel piers of dual bridge structure A5585 on State Highway 364 near

St. Louis, Missouri

15. Diagram showing key features, substructural and superstructural details, and surveyed channel bed along the upstream face of each bridge of dual bridge structure A5585 on State Highway 364 over the Missouri River near St. Louis, Missouri.

16. Aerial photograph showing location of the bathymetric survey area on the Missouri River near structures A3292 and L0561 on Interstate 70 near St. Louis, Missouri.

17. Bathymetric survey of the Missouri River channel in the vicinity of structures A3292 and L0561 on Interstate 70 near St. Louis, Missouri.. 
18. Bathymetric survey of the Missouri River channel in the vicinity of the left main channel piers of structures A3292 and L0561 on Interstate 70 near St. Louis,

Missouri.

19. Diagram showing key features, substructural and superstructural details, and surveyed channel bed of structure A3292 on Interstate 70 over the Missouri River near St. Louis, Missouri

20. Diagram showing key features, substructural and superstructural details, and surveyed channel bed of structure L0561 on Interstate 70 over the Missouri River near St. Louis, Missouri

21. Bathymetric survey of the Missouri River channel in the vicinity of the right main channel piers of structures A3292 and L0561 on Interstate 70 near St. Louis, Missouri...

22. Aerial photograph showing location of the bathymetric survey area on the Missouri River near dual bridge structure A4557 on State Highway 370 near St. Louis, Missouri.

23. Bathymetric survey of the Missouri River channel in the vicinity of dual bridge structure A4557 on State Highway 370 near St. Louis, Missouri...

24. Bathymetric survey of the Missouri River channel in the vicinity of the main channel piers of dual bridge structure A4557 on State Highway 370 near St. Louis, Missouri.

25. Point cloud visualization of the channel bed and left (west) side of upstream pier 3C of dual bridge structure A4557 on State Highway 370 over the Missouri River near St. Louis, Missouri

26. Diagram showing key features, substructural and superstructural details, and surveyed channel bed along the upstream face of each bridge of dual bridge structure A4557 on State Highway 370 over the Missouri River near St. Louis, Missouri.

27. Aerial photograph showing location of the bathymetric survey area on the Missouri River near structure A3047 on U.S. Highway 67 near St. Louis, Missouri ........41

28. Bathymetric survey of the Missouri River channel in the vicinity of structure A3047on U.S. Highway 67 near St. Louis, Missouri

29. Bathymetric survey of the Missouri River channel in the vicinity of the left main channel pier of structure A3047 on U.S. Highway 67 near St. Louis, Missouri

30. Diagram showing key features, substructural and superstructural details, and surveyed channel bed of structure A3047 on U.S. Highway 67 over the Missouri River near St. Louis, Missouri.

31. Bathymetric survey of the Missouri River channel in the vicinity of the central main channel pier of structure A3047 on U.S. Highway 67 near St. Louis, Missouri.......45

32. Bathymetric survey of the Missouri River channel in the vicinity of the right main channel pier of structure A3047 on U.S. Highway 67 near St. Louis, Missouri .

33. Aerial photograph showing location of the bathymetric survey area on the Mississippi River near structure A1500 on Interstate 55 near St. Louis, Missouri.....

34. Bathymetric survey of the Mississippi River channel in the vicinity of structure A1500 on Interstate 55 near St. Louis, Missouri ....

35. Bathymetric survey of the Mississippi River channel in the vicinity of the $A$, left bank, and $B$, left main channel piers of structure A1500 on Interstate 55 near St. Louis, Missouri....

36. Diagram showing key features, substructural and superstructural details, and surveyed channel bed of structure A1500 on Interstate 55 over the Mississippi River near St. Louis, Missouri. 
37. Point cloud visualization of the channel bed and right (west) side of the left main channel pier (pier 4) of structure A1500 on Interstate 55 over the Mississippi River near St. Louis, Missouri

38. Bathymetric survey of the Mississippi River channel in the vicinity of the $A$, right main channel and, $B$, right bank piers of structure A1500 on Interstate 55 near St. Louis, Missouri

39. Bathymetric survey of the Mississippi River channel in the vicinity of the $A$, left and $B$, right main channel piers of the MacArthur Railroad Bridge downstream fromstructure A1500 on Interstate 55 near St. Louis, Missouri

40. Photograph showing a partially sunken barge trapped on the nose of the left main channel pier of the MacArthur railroad bridge over the Mississippi River downstream from structure A1500 on Interstate 55 near St. Louis, Missouri....

41. Aerial photograph showing location of the bathymetric survey area on the Mississippi River near structures A4936 and A1850 on Interstate 255 near St. Louis, Missouri

42. Bathymetric survey of the Mississippi River channel in the vicinity of structures A4936 and A1850 on Interstate 255 near St. Louis, Missouri .59

43. Bathymetric survey of the Mississippi River channel in the vicinity of the main channel piers of structures A4936 and A1850 on Interstate 255 near St. Louis, Missouri.

44. Diagram showing key features, substructural and superstructural details, and surveyed channel bed along the upstream face of each bridge of identical structures A4936 and A1850 on Interstate 255 over the Mississippi River near St. Louis, Missouri

45. Point cloud visualization of the channel bed and left (east) side of main channel pier 9 of structures A4936 and A1850 on Interstate 255 over the Mississippi River near St. Louis, Missouri

46. Point cloud visualization of the channel bed and left (east) side of main channel pier 12 of structures A4936 and A1850 on Interstate 255 over the Mississippi River near St. Louis, Missouri.

47. Difference between bathymetric survey of the Mississippi River channel in the vicinity of structures A4936 and A1850 on Interstate 255 near St. Louis, Missouri, on October 19, 2010, and bathymetric surveys on $A$, October 2-3, 2008, $B$, May 12-13, 2009, and, C, July 8, 2009

48. Difference between bathymetric survey of the Mississippi River channel in the vicinity of the main channel piers of structures A4936 and A1850 on Interstate 255 near St. Louis, Missouri, on October 19, 2010, and bathymetric surveys on A, October 2-3, 2008, B, May 12-13, 2009, and, C, July 8, 2009

49. Diagram showing key features, substructural and superstructural details, and surveyed channel bed along the upstream face of upstream structure A4936 on Interstate 255 over the Mississippi River near St. Louis, Missouri, from surveys on different dates.

50. Graphs showing longitudinal profiles upstream from piers at structures A4017, J1000, and A5585 on the Missouri River near St. Louis, Missouri..

51. Graphs showing longitudinal profiles upstream from piers at structures A3292, L0561, A4557, and A3047 on the Missouri River near St. Louis, Missouri..

52. Graphs showing longitudinal profiles upstream from piers at structures A1500, A4936, and A1850 on the Mississippi River near St. Louis, Missouri

53. Graphs showing longitudinal profiles upstream from railroad bridge piers near structures A4557, A3047, and A1500 on the Missouri and Mississippi Rivers near St. Louis, Missouri 


\section{Tables}

1. Bridges crossing the Missouri and Mississippi Rivers in the St. Louis, Missouri, metropolitan area, in downstream order.

2. Results of a beam angle check from two check lines over a reference surface at Blue Springs Lake, Missouri, on October 26, 2010.

3. Patch test results from surveying on the Missouri and Mississippi Rivers near St. Louis, Missouri

4. Total propagated error results for bathymetric data at a 1-meter grid spacing from surveys on the Missouri and Mississippi Rivers near St. Louis, Missouri, from October 18-25, 2010

5. Bridge and survey information, and minimum elevation in the channel from surveys on the Missouri and Mississippi Rivers near St. Louis, Missouri, from October 18-25, 2010.

6. Results near piers from surveys on the Missouri River near St. Louis, Missouri, from October 18-25, 2010 15

7. Results near piers from surveys on the Mississippi River near St. Louis, Missouri, from October 19-20, 2010.

\section{Conversion Factors and Datums}

Inch/Pound to SI

\begin{tabular}{|c|c|c|}
\hline Multiply & By & To obtain \\
\hline \multicolumn{3}{|c|}{ Length } \\
\hline inch (in.) & 2.54 & centimeter $(\mathrm{cm})$ \\
\hline foot $(\mathrm{ft})$ & 0.3048 & meter $(\mathrm{m})$ \\
\hline mile (mi) & 1.609 & kilometer (km) \\
\hline \multicolumn{3}{|c|}{ Flow rate } \\
\hline cubic foot per second $\left(\mathrm{ft}^{3} / \mathrm{s}\right)$ & 0.02832 & cubic meter per second $\left(\mathrm{m}^{3} / \mathrm{s}\right)$ \\
\hline
\end{tabular}

Vertical coordinate information is referenced to the North American Vertical Datum of 1988 (NAVD 88). The difference between NAVD 88 and the National Geodetic Vertical Datum of 1929 (NGVD 29) is -0.21 to 0.16 foot throughout the study area, with an average value of -0.09 foot. Horizontal coordinate information is referenced to the North American Datum of 1983 (NAD 83). In this report, the words "left" and "right" generally refer to directions that would be reported by an observer facing downstream. 



\title{
Bathymetric Surveys at Highway Bridges Crossing the Missouri and Mississippi Rivers near St. Louis, Missouri, 2010
}

\author{
By Richard J. Huizinga
}

\section{Abstract}

Bathymetric surveys were conducted by the U.S. Geological Survey, in cooperation with the Missouri Department of Transportation, on the Missouri and Mississippi Rivers in the vicinity of 12 bridges at 7 highway crossings near St. Louis, Missouri, in October 2010. A multibeam echo sounder mapping system was used to obtain channel-bed elevations for river reaches ranging from 3,280 to 4,590 feet long and extending across the active channel of the Missouri and Mississippi Rivers. These bathymetric scans provide a snapshot of the channel conditions at the time of the surveys and provide characteristics of scour holes that may be useful in the development of predictive guidelines or equations for scour holes. These data also may be used by the Missouri Department of Transportation to assess the bridges for stability and integrity issues with respect to bridge scour.

Bathymetric data were collected around every pier that was in water, except those at the edge of water or in extremely shallow water, and one pier that was surrounded by a large debris raft. Scour holes were present at most piers for which bathymetry could be obtained, and ranged from 0 to 16 feet deep except at piers on channel banks or those near or embedded in rock dikes. Scour holes observed at the surveyed bridges were examined with respect to frontal slope and shape, and scour holes near railroad bridges in the vicinity of the highway bridges also were examined. Although exposure of parts of foundational support elements was observed at several piers, the exposure likely can be considered minimal compared to the overall substructure that remains buried at these piers.

At piers with well-defined scour holes, the frontal slopes of the holes ranged from 1.70 to 2.94 feet per foot (computed as run over rise), which were similar to recommended values in the literature (generally ranging from 1.0 to 2.0 ), and the shapes of the scour holes were not substantially affected by the movement of sand waves into the holes. Spur dikes near several of the piers caused localized flow disturbances that caused the resultant scour holes to display characteristics of skewed approach flow. The channel bed in the 2010 surveys was as much as 16 feet lower than the channel bed at the time of construction at the two oldest surveyed bridges, and the range varied with age of the structure, indicating the channel-bed elevations have lowered with time. However, other research has indicated the extremely dynamic nature of the channel bed on the Mississippi River.

The size of the scour holes observed at the surveyed sites likely was affected by the low to moderate flow conditions on the Missouri and Mississippi Rivers at the time of the surveys. The scour holes likely would be larger during conditions of increased flow. Artifacts of horizontal positioning errors were present in the data, but an analysis of the surveys indicated that most of the bathymetric data have a total propagated error of less than 0.33 foot.

\section{Introduction}

Scour in alluvial channels is the removal of channel bed and bank material by flowing water, and is the leading cause of bridge failures in the United States (Richardson and Davis, 2001). Scour at a bridge site is the result of short- and long-term geomorphic processes and the local effects caused by elements of the structure in or adjacent to the waterway (Richardson and Davis, 2001; Huizinga and Rydlund, 2004). Because the effects can be severe and dangerous, bridges and other structures over waterways are routinely assessed and inspected for the effects of scour.

The Missouri Department of Transportation (MoDOT) is responsible for most of the transportation infrastructure that benefits the welfare of Missouri citizens. A part of this responsibility is fulfilled through periodic inspections of highway structures, including bridges that span waterways throughout the state. At most of these structures, all or most of the structure can be fully inspected from land or from personnel lift trucks deployed from the roadway of the structure; however, for structures over major waterways, such as the Missouri and Mississippi Rivers, inspection of the part of the bridge that is underwater requires a different approach. 
The U.S. Geological Survey (USGS), in cooperation with MoDOT, began assessing scour at waterway crossings throughout the state in 1991 (Huizinga and Rydlund, 2004). In 2007 , the USGS began determining channel bathymetry and monitoring bridges for scour using single beam echo sounders and a multibeam mapping system (Rydlund, 2009; Huizinga, 2010; Huizinga and others, 2010). In particular, the multibeam mapping system has proven to be a useful tool not only in determining channel bathymetry, but also in providing medium- to high-resolution imagery of bridge structural elements below the water line; therefore, in 2010 the USGS, in cooperation with MoDOT, began conducting a series of bathymetric surveys at various highway bridges across major waterways in Missouri. In March 2010, 9 highway bridges at 7 crossings over the Missouri River in Kansas City, Missouri, were assessed using the multibeam mapping system; these results are documented in a report by Huizinga (2010).

In the St. Louis, Missouri, metropolitan area upstream from the confluence of the Missouri and Mississippi Rivers, there are 9 highway bridges and 2 railroad bridges that span the Missouri River and 1 highway bridge that spans the Mississippi River. Downstream from the confluence, 7 additional highway bridges, 1 pedestrian bridge, and 2 additional railroad bridges span the Mississippi River in the St. Louis, Missouri, metropolitan area (fig. 1; table 1). MoDOT is responsible for 12 of the 17 highway bridges that were assessed specifically as part of this study (table 1). Three of the railroad bridges also were surveyed as part of this study because of their proximity to the MoDOT bridges (table 1). On the Missouri River upstream from the confluence with the Mississippi, two of the crossings are in a dual bridge configuration, consisting of two bridges with the same structure number: the State Highway 364 (structure A5585 East \& West) and State Highway 370 (structure A4557 East \& West). Three of the other crossings consist of two bridges, each with separate structure numbers: the U.S. Highway 40 crossing of the Missouri River consists of structures A4017 and J1000; the Interstate 70 crossing of the Missouri River consists of structures A3292 and L0561; and the Interstate 255 crossing of the Mississippi River consists of structures A4936 and A1850. Therefore, 12 highway bridges at 7 unique crossings of the Missouri and Mississippi Rivers in the St. Louis metropolitan area routinely are inspected by MoDOT (Jennifer Harper, Missouri Department of Transportation, written commun., 2010).

\section{Purpose and Scope}

The purpose of this report is to document bathymetric surveys of the Missouri and Mississippi River channel in the vicinity of 12 highway bridges at 7 crossings of the rivers in the St. Louis, Missouri, metropolitan area obtained by using a multibeam echo sounder in 2010. Equipment and methods used and results obtained are described. The results obtained from the bathymetric surveys of the channel provide a snapshot of the channel conditions at the time of the surveys and provide characteristics of scour holes that may be useful in developing predictive guidelines or equations for scour holes. These data also may be used by MoDOT to assess the bridges for stability and integrity issues with respect to bridge scour.

\section{Description of Study Area}

The overall study area for this report is the Missouri and Mississippi Rivers in the St. Louis metropolitan area, which encompasses the numerous cities and towns near St. Louis, Missouri, including the City of St. Louis, St. Louis County, and parts of St. Charles and Jefferson Counties (fig. 1). The Missouri River flows through the St. Louis metropolitan area from west to east, joining the Mississippi River north of downtown St. Louis. The Missouri and Mississippi Rivers are channelized in the St. Louis area, with rock revetment, spur dikes, and L-head dikes along the banks to maintain the channel alignment. Near downtown St. Louis, the Mississippi River also is bordered on both banks with levees and floodwalls to limit flooding in the industrial, commercial, and residential areas in the floodplains.

The Missouri and Mississippi Rivers were in low to moderate flow conditions when the bathymetric surveys were performed October 18-25, 2010. On the Missouri River, the discharge ranged from 87,400 to 95,300 cubic feet per second $\left(\mathrm{ft}^{3} / \mathrm{s}\right)$, as measured at the USGS streamflow-gaging station (hereinafter referred to as "streamgage") on the Missouri River at St. Charles, Missouri (station 06935965), located upstream from the Wabash railroad bridge (fig. 1; U.S. Geological Survey, 2011). This discharge range has a daily exceedance of 30 to 34 percent (U.S. Geological Survey, 2003), and is substantially less than the 50 percent annual exceedance probability (2-year recurrence interval) flood discharge of 250,000 ft $3 / \mathrm{s}$ (U.S. Army Corps of Engineers, 2004a). Similarly, on the Mississippi River, the discharge ranged from 277,000 to 288,000 $\mathrm{ft}^{3} / \mathrm{s}$, as measured at the USGS streamgage on the Mississippi River at St. Louis, Missouri (station 07010000), located on the Eads Bridge (fig. 1; U.S. Geological Survey, 2011). This discharge range has a daily exceedance of 17 to 19 percent (U.S. Geological Survey, 2003) and is substantially less than the 50 percent annual exceedance probability (2-year recurrence interval) flood discharge of 450,000 ft3 $/ \mathrm{s}$ (U.S. Army Corps of Engineers, 2004b).

\section{Description of Equipment}

The bathymetry of the Missouri and Mississippi Rivers at each of the bridges was determined using a high-resolution multibeam mapping system. The various components of the multibeam mapping system used for this study are the same as were used in a similar study at various bridges on the Missouri River in Kansas City, Missouri (Huizinga, 2010), and in a previous study on the Mississippi River near St. Louis, Missouri (Huizinga and others, 2010). The survey methods used to obtain the data were similar to these previous studies, as were 


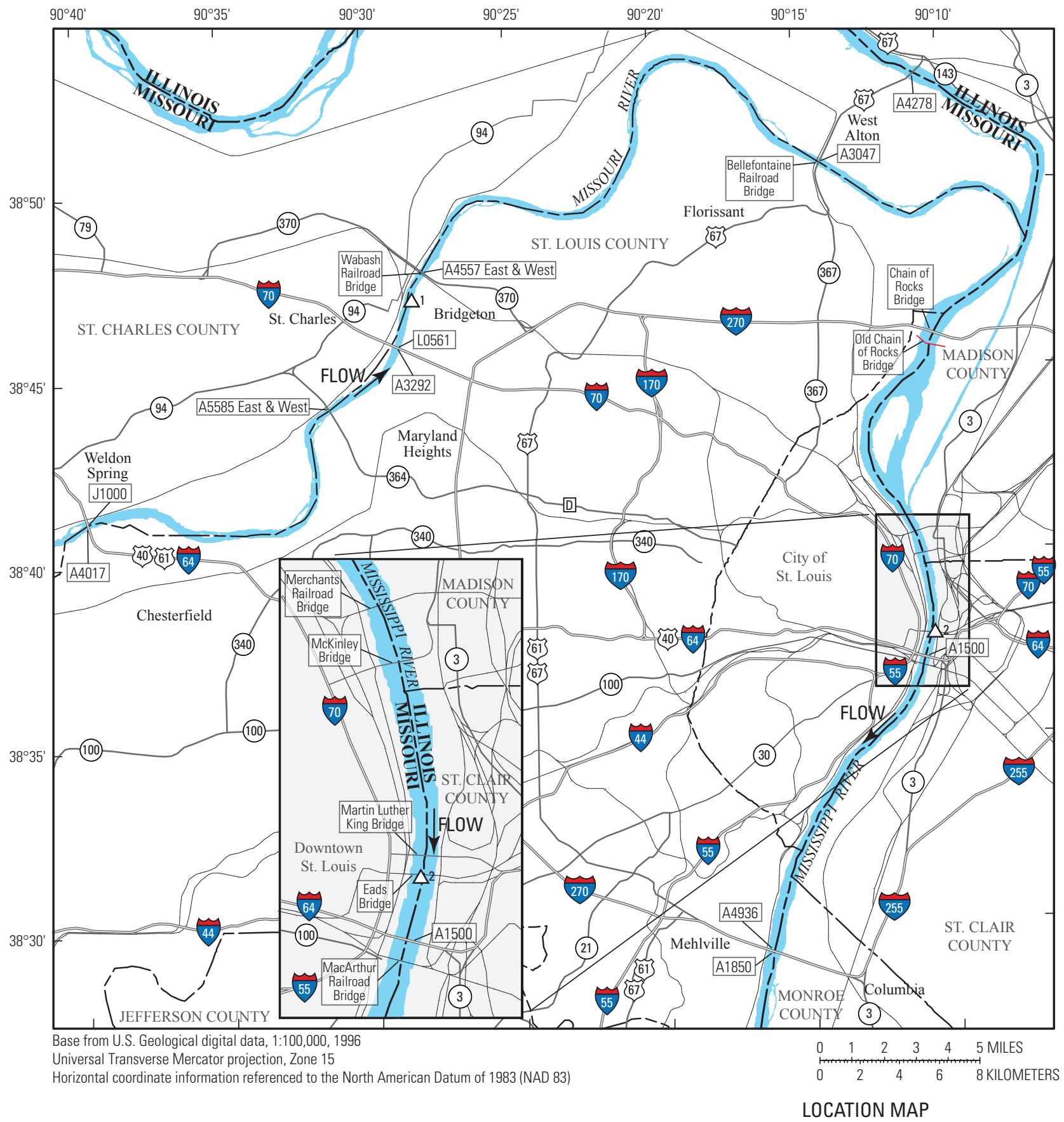

\section{EXPLANATION}

Principal railroad route

$\Delta 1 \quad$ U.S. Geological Survey streamflow-gaging station on the Missouri River at St. Charles, station 06935965

$\Delta^{2} \quad$ U.S. Geological Survey streamflow-gaging station on the Mississippi River at St. Louis, station 07010000

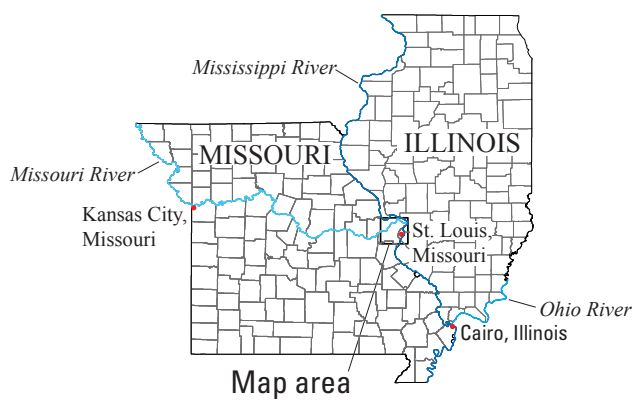

Figure 1. Location of bridges crossing the Missouri and Mississippi Rivers in the St. Louis, Missouri, metropolitan area. 
Table 1. Bridges crossing the Missouri and Mississippi Rivers in the St. Louis, Missouri, metropolitan area, in downstream order.

[MoDOT, Missouri Department of Transportation; US, United States highway; E, Eastbound; W, Westbound; MO, Missouri State highway; IS, Interstate highway; --, not known/applicable; NS, Norfolk and Southern, BNSF, Burlington Northern Santa Fe; TRR-StL, Terminal Railroad of St. Louis; S, southbound; N, northbound; gray shading indicates structures on the Mississippi River]

\begin{tabular}{|c|c|c|c|c|c|c|}
\hline $\begin{array}{c}\text { MoDOT } \\
\text { structure } \\
\text { number }\end{array}$ & Local name & County & Route & $\begin{array}{l}\text { Surveyed } \\
\text { as part of } \\
\text { this study }\end{array}$ & Remarks & Figures \\
\hline A4017 & Daniel Boone & St. Charles & US 40E & Yes & Dual bridge crossing with J1000 & $1,4,5,6,7,8,9,10,11,50$ \\
\hline $\mathrm{J} 1000$ & Daniel Boone & St. Louis & US 40W & Yes & Dual bridge crossing with A4017 & $1,4,5,6,7,8,9,10,11,50$ \\
\hline A5585 E & Page Avenue & St. Charles & MO 364E & Yes & Dual bridge crossing & $1,12,13,14,15,50$ \\
\hline A5585 W & Page Avenue & St. Louis & MO 364W & Yes & Dual bridge crossing & $1,12,13,14,15,50$ \\
\hline L0561 & Blanchette & St. Louis & IS 70W & Yes & Dual bridge crossing with A3292 & $1,16,17,18,19,20,21,51$ \\
\hline-- & Wabash & St. Louis & NS & Yes $^{\mathrm{a}}$ & Railroad bridge & $1,22,23,24,53$ \\
\hline A4557 E & Discovery & St. Charles & MO 370E & Yes & Dual bridge crossing & $1,22,23,24,25,26,51$ \\
\hline A4557 W & Discovery & St. Louis & MO 370W & Yes & Dual bridge crossing & $1,22,23,24,26,51$ \\
\hline-- & Chain of Rocks & Madison, Ill. & IS 270 & No & Owned by Illinois DOT & 1 \\
\hline-- & $\begin{array}{l}\text { Old Chain of } \\
\text { Rocks }\end{array}$ & Madison, Ill. & Old US 66 & No & Pedestrian only & 1 \\
\hline-- & Merchants & St. Louis City & TRR-StL & No & Railroad bridge & 1 \\
\hline-- & McKinley & St. Louis City & -- & No & Owned by Illinois DOT & 1 \\
\hline-- & $\begin{array}{l}\text { Martin Luther } \\
\text { King }\end{array}$ & St. Louis City & -- & No & Owned by Illinois DOT & 1 \\
\hline-- & Eads & St. Louis City & -- & No & Owned by City of St. Louis & 1 \\
\hline A 1500 & Poplar Street & St. Louis City & IS 55 & Yes & -- & $1,33,34,35,36,37,38,52$ \\
\hline
\end{tabular}

${ }^{a}$ Railroad bridge was surveyed because of proximity to a MoDOT bridge that was assessed specifically as part of this study. No structural information was provided for this bridge, and only the size and shape of any existing scour hole were examined.

the measures used to ensure data quality. A brief description of the equipment follows; a complete description of the various system components and methods used in this study is available in a previous report by Huizinga (2010).

A multibeam mapping system is an integration of several individual components: the multibeam echo sounder (MBES), a navigation and motion-sensing system, and a data-collection and processing computer. The MBES that was used is the RESON SeaBat ${ }^{\mathrm{TM}} 7125$, operating at a frequency of 400 kilohertz (kHz). The navigation and motion-sensing system that was used is the Applanix Position Orientation Solution for Marine Vessels (POS MV ${ }^{\mathrm{TM}}$ ) WaveMaster system (hereinafter referred to as "the POS"). The navigation system locates the MBES in three-dimensional space, and the motion-sensing system measures the heave, pitch, roll, and heading of the vessel (and, thereby, the MBES) to accurately position the data received by the MBES.

As in previous studies (Huizinga, 2010; Huizinga and others, 2010), the Global Positioning System (GPS) base station used for the real-time kinetic (RTK) navigation and tide solution during the survey was set up on the river bank, near the bridge to be surveyed. Consequently, the bridge structure would block a part of or the entire signal from the GPS constellation of satellites when the survey vessel was near or under the bridge, resulting in a GPS outage that had the potential to degrade the positional accuracy of the vessel until such time as an RTK-fixed navigation solution was re-acquired; however, as in the Kansas City study (Huizinga, 2010), the navigation information from the survey was post-processed using the POS-Pac ${ }^{\mathrm{TM}}$ Mobile Mapping Suite $\left(\mathrm{MMS}^{\mathrm{TM}}\right)$ software (Applanix Corporation, 2009), which provided tools to 
identify and compensate for sensor and environmental errors and computed an optimally blended navigation solution from the GPS and inertial motion unit (IMU) raw data. The blended navigation solution (called a "standard best-estimate of travel" or "SBET" file) generated by post-processing the navigation data was applied to the entire survey at a given bridge to minimize the effects of the GPS outages while surveying under the bridges.

The data from the MBES and navigation and motionsensing components were processed and integrated into a cohesive dataset for cleanup and visualization. A laptop computer onboard the survey boat ran the HYPACK ${ }^{\circledR} /$ HYSWEEP $^{\circledR}$ data acquisition software (HYPACK, Inc., 2009), which was used to prepare for the bathymetric surveys and collect the survey data. Upon completion of the surveys, the acquired depth data were further processed to remove data spikes and other spurious points in the multibeam swath trace, and were georeferenced using the navigation and position solution data from the SBET file from POS-Pac ${ }^{\mathrm{TM}} \mathrm{MMS}^{\mathrm{TM}}$, and were visualized in $\mathrm{HYPACK}^{\circledR} / \mathrm{HYSWEEP}^{\circledR}$ as a triangulated irregular network (TIN) surface or a point cloud. The georeferenced data were output to a comma-delimited file either with no data reduction, or filtered and reduced based on a desired data resolution. These comma-delimited data were compiled into a geographic information system (GIS) database for each site using the ArcGIS package (Environmental Systems Research Institute, 2010).

\section{Basic Description of Methods}

The methods used to acquire and assure the collection of quality data were the same as those used in previous studies with the MBES (Huizinga, 2010; Huizinga and others, 2010), and the reader is referred to those reports for the details of the methods used. A brief summary of and differences from these methods are highlighted below.

\section{Surveying Methods}

The size of the surveyed area at each site was dictated somewhat by the flow conditions. Because of the low to moderate flow conditions on the Missouri and Mississippi Rivers during survey dates (October 18-25, 2010), many of the rock spur and L-head dikes were not submerged; therefore, it was impossible to survey from bank to bank as had been done in the Kansas City study (Huizinga, 2010). Generally, the surveyed areas extended across the active channel between L-head dikes or banks on one side of the channel to the shallows in the vicinity of the spur dikes on the opposite side. The surveyed areas were from 3,280 to 4,590 feet (ft) long, positioned so that the surveyed highway bridges were approximately one-third to one-half of the total length from the upstream boundary. The upstream and downstream boundaries of the surveyed areas were assumed to be beyond the hydraulic effect of the bridge structures.
As in previous studies, each survey was designed so that there was overlap of the survey swaths to ensure complete coverage of the channel bed and minimize sonic "shadows." Substantial overlap was achieved for many of the surveyed swaths, except in shallow areas near the channel banks or spur dikes, or near debris rafts. To minimize data acquisition times in the shallows, data between the swaths often were interpolated in areas of minimal relief. The presence of debris rafts made surveying difficult or impossible at some piers.

\section{Survey Quality-Assurance/Quality-Control Measures}

For the MBES mapping system, the principal qualityassurance assessments were performed in real time during the survey. The MBES operator continuously was assessing the quality of the collected data during the survey, making visual observations of across-track swaths (such as convex, concave, or skewed bed returns in flat, smooth bottoms), noting data quality flags and alarms from the MBES and the POS, and noting comparisons between adjacent overlapping swaths. In addition to the real-time quality-assurance assessments during the survey, several tests were performed to ensure the data quality acquired by the MBES mapping system. For this survey, a beam angle check and a suite of patch tests were performed to ensure quality data were acquired from the MBES mapping system.

\section{Beam Angle Check}

A beam angle check is used to determine the accuracy of the depth readings obtained by the outer beams of the MBES (U.S. Army Corps of Engineers, 2004c). The HYPACK ${ }^{\circledR /}$ HYSWEEP ${ }^{\circledR}$ software has a program that performs a statistical assessment of the quality of the outer beams compared to a reference surface. On October 26, 2010, a reference surface was created for a part of Blue Springs Lake near Blue Springs, Missouri, in the same location as a beam angle check for the Kansas City surveys (Huizinga, 2010), and check lines were run across the reference surface. The results of the beam angle check (table 2) were within the recommended standards utilized by the U.S. Army Corps of Engineers for hydrographic surveys for all angles less than 70 degrees from nadir (U.S. Army Corps of Engineers, 2004c), permitting the use of the full sonar swath.

\section{Patch Tests}

Patch tests are a series of dynamic calibration tests that are used to check for subtle variations in the orientation and timing of the MBES with respect to the POS and real-world coordinates. The patch tests are used to determine timing offsets caused by latency between the MBES and the POS, and angular offsets to roll, pitch, and yaw caused by the alignment of the transducer head (fig. 2). A set of patch tests 
Table 2. Results of a beam angle check from two check lines over a reference surface at Blue Springs Lake, Missouri, on October 26, 2010.

[ft, feet; <, less than: --, no data]

\begin{tabular}{ccccc}
\hline $\begin{array}{c}\text { Beam angle } \\
\text { limit } \\
\text { (degrees) }\end{array}$ & $\begin{array}{c}\text { Maximum } \\
\text { outlier } \\
\text { (ft) }\end{array}$ & $\begin{array}{c}\text { Mean } \\
\text { difference } \\
\text { (ft) }\end{array}$ & $\begin{array}{c}\text { Standard } \\
\text { deviation } \\
\text { (ft) }\end{array}$ & $\begin{array}{c}\text { 95 percent } \\
\text { confidence } \\
\text { (ft) }\end{array}$ \\
\hline 20 & 0.62 & 0 & 0.07 & 0.16 \\
25 & .62 & 0 & .07 & .16 \\
30 & .62 & 0 & .07 & .16 \\
35 & .62 & 0 & .07 & .16 \\
40 & .62 & 0 & .10 & .16 \\
45 & .62 & 0 & .10 & .16 \\
50 & .62 & 0 & .10 & .16 \\
55 & .62 & 0 & .10 & .16 \\
60 & .66 & 0 & .10 & .20 \\
65 & .66 & 0 & .10 & .23 \\
70 & .66 & 0 & .10 & .23 \\
Performance & 1.00 & $<.20$ & -- & $<.50$ \\
standards ${ }^{\mathrm{a}}$ & & & & \\
Within standards & Yes & Yes & -- & Yes
\end{tabular}

a Performance standard check values are from U.S. Army Corps of Engineers $(2004 \mathrm{c})$, table $3-1$.

was performed each day of surveying, and a summary of the results is shown in table 3 .

For this study, there was no measured timing offset $(\Delta t=$ 0 ; table 3), which is consistent with latency test results for this boat and configuration used in other surveys (Huizinga, 2010; Huizinga and others, 2010; Richard Huizinga, U.S. Geological Survey, unpub. data, 2010). The measured angular offset for pitch equaled a constant value of -1.80 degrees (table 3 ), which is consistent with the angular offset for pitch value determined for this boat during previous surveys (Huizinga, 2010; Richard Huizinga, unpub. data, 2010).

The measured angular offset, in degrees, for roll was 0.30 on the first, third and fourth survey days, 0.10 on the second survey day, and 0 on the last survey day (table 3 ). This range of values - particularly the larger value of 0.30 - is consistent with angular offset for roll values determined for this boat during previous surveys (Huizinga, 2010; Richard Huizinga, unpub. data, 2010); however, the change in value from one day to the next was not consistent, as had been observed during the Kansas City study (Huizinga, 2010). Ultimately, no specific causal factor was identified for the changing value during the surveys.

The measured angular offset for yaw was 2.50 degrees on the second day of surveying, and 2.70 for the other days (table 3). These values are consistent with angular offset for yaw values determined for this boat during the previous survey in Kansas City (Huizinga, 2010) and other recent surveys (Richard Huizinga, unpub. data, 2010). It was noted in Huizinga (2010) that a sensitivity analysis of the four offsets implied that the ultimate position of surveyed points in threedimensional space was least sensitive to the angular offset for yaw, whereas it was most sensitive to the angular offset for roll.

The bathymetric data were processed to apply the patch test corrections for each day of surveying and to remove data spikes and other spurious points in the multibeam swaths. The bathymetric data were then projected to a three-dimensional grid at a resolution of $0.82 \mathrm{ft}$ (high resolution) near the bridge pier(s) and $3.28 \mathrm{ft}$ (low resolution) for the remainder of the surveyed area. The bathymetric data were used to generate a TIN of the channel bed in the vicinity of each bridge using ArcGIS.

\section{Error Estimation}

To estimate the potential errors in the surveys, the Combined Uncertainty Bathymetric Estimator (CUBE) method (Calder and Mayer, 2003) as implemented in the HYPACK ${ }^{\circledR /}$ HYSWEEP ${ }^{\circledR}$ software (HYPACK, Inc., 2009) was used to estimate total propagated error (TPE) for the gridded surface of each survey area. The CUBE method allows all random system component errors and resolution effects to be combined and propagated through the data processing steps, which provides a robust estimate of the spatial distribution of possible error within the survey area (Czuba and others, 2011). Thus, the TPE of a point is a measure of the accuracy to be expected for such a point, when all relevant error sources are taken into account (Czuba and others, 2011). Statistics of TPE for each of the survey areas are shown in table 4, and an example of the spatial distribution of TPE typically observed in the survey data is shown in figure 3 for the bathymetric data at structures A4936 and A1850.

The largest TPE in the St. Louis surveys was about $5.5 \mathrm{ft}$ (table 4); however, TPE values of this magnitude typically occurred near high-relief features, such as the front or side of a pier footing or large submerged object (fig. 3). A vast majority (over 99.5 percent) of TPE values were less than $1.6 \mathrm{ft}$ (table 4), with larger values occurring near moderaterelief features (banks, dune faces, rock dikes, and scour holes; fig. 3). Occasionally, these larger TPE values also occurred in the outermost beam parts of the multibeam swath in the overlap with an adjacent swath, typically in the channel thalweg where substantial bed movement would occur between survey passes, or - particularly in the case of structures A4936 and A1850 - in areas where sound velocity values were observed to be unusual (fig. 3). Substantial parts (approximately 80 percent or more) of the channel bed at all of the surveyed sites had TPE values of $0.5 \mathrm{ft}$ or less, and over half of the bathymetry data had a TPE value of $0.33 \mathrm{ft}$ or less (table 4). The tops of bridge substructural elements (pier footings and seal courses) typically had TPE values of $0.2 \mathrm{ft}$ or less. 


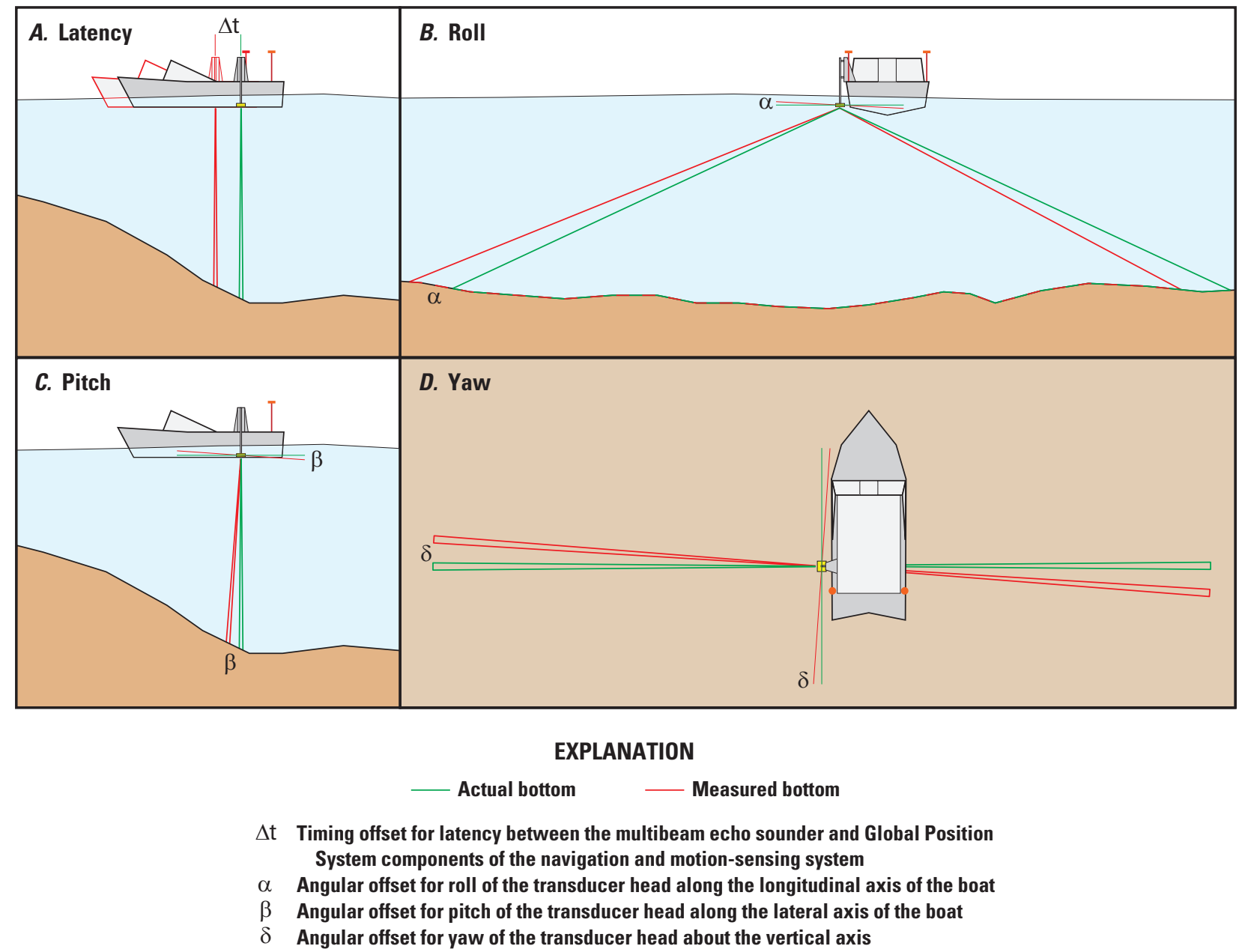

Figure 2. Effects of $A$, timing offset for latency, and angular offsets for, $B$, roll, $C$, pitch, and $D$, yaw on data from a multibeam echo sounder.

Table 3. Patch test results from surveying on the Missouri and Mississippi Rivers near St. Louis, Missouri.

[sec, seconds; deg, degrees; IS, Interstate highway; MO, Missouri State highway; US, United States highway]

\begin{tabular}{cccccc}
\hline Date of test & $\begin{array}{c}\text { Timing offset } \\
(\mathbf{s e c})\end{array}$ & $\begin{array}{c}\text { Angular offset } \\
\text { for roll } \\
(\mathbf{d e g})\end{array}$ & $\begin{array}{c}\text { Angular offset } \\
\text { for pitch } \\
\text { (deg) }\end{array}$ & $\begin{array}{c}\text { Angular offset } \\
\text { for yaw } \\
\text { (deg) }\end{array}$ & Location (fig. 1) \\
\hline $10 / 19 / 10$ & 0 & 0.30 & -1.80 & 2.70 & $\begin{array}{c}\text { Mississippi River near St. Louis, at IS 255 } \\
\text { (A4936/A1850) } \\
\text { Mississippi River near St. Louis, at IS 55 } \\
\text { (A1500) }\end{array}$ \\
$10 / 20 / 10$ & 0 & .10 & -1.80 & 2.50 & $\begin{array}{c}\text { Missouri River near St. Louis, at IS 70 } \\
\text { (A3292/L0561) }\end{array}$ \\
$10 / 21 / 10$ & 0 & .30 & -1.80 & 2.70 & $\begin{array}{c}\text { Missouri River near St. Louis, at MO 370 } \\
\text { (A4557 E \& W) }\end{array}$ \\
$10 / 22 / 10$ & 0 & .30 & -1.80 & 2.70 & $\begin{array}{c}\text { Missouri River near St. Louis, at US 67 } \\
\text { (A3047) }\end{array}$ \\
\hline
\end{tabular}


Table 4. Total propagated error results for bathymetric data at a 1-meter grid spacing from surveys on the Missouri and Mississippi Rivers near St. Louis, Missouri, from October 18-25, 2010.

[MoDOT, Missouri Department of Transportation; ft, feet; E, Eastbound; W, Westbound]

\begin{tabular}{|c|c|c|c|c|c|c|c|}
\hline \multirow{2}{*}{$\begin{array}{c}\text { MoDOT } \\
\text { structure } \\
\text { number } \\
\text { (fig. 1) }\end{array}$} & \multirow{2}{*}{$\begin{array}{c}\text { Maximum } \\
\text { value of error } \\
\text { (ft) }\end{array}$} & \multirow{2}{*}{$\begin{array}{l}\text { Mean value of } \\
\text { error } \\
\text { (ft) }\end{array}$} & \multirow{2}{*}{$\begin{array}{c}\text { Standard } \\
\text { deviation of } \\
\text { error } \\
\text { (ft) }\end{array}$} & \multicolumn{4}{|c|}{ Percent of bathymetry points with error value less than } \\
\hline & & & & $1.64 \mathrm{ft}$ & $0.82 \mathrm{ft}$ & $0.50 \mathrm{ft}$ & $0.33 \mathrm{ft}$ \\
\hline A4017/J1000 & 3.64 & 0.35 & 0.25 & 99.7 & 93.7 & 81.3 & 57.6 \\
\hline A5585 E \& W & 3.12 & .30 & .22 & 99.9 & 96.2 & 86.5 & 64.8 \\
\hline A3292/L0561 & 5.02 & .32 & .22 & 99.9 & 95.6 & 85.3 & 61.5 \\
\hline A4557 E \& W & 4.36 & .29 & .20 & 99.9 & 97.3 & 88.8 & 66.9 \\
\hline A 3047 & 4.17 & .28 & .22 & 99.9 & 96.3 & 88.9 & 71.9 \\
\hline A 1500 & 5.02 & .36 & .24 & 99.6 & 95.4 & 82.7 & 51.6 \\
\hline A4936/A1850 & 5.54 & .38 & .25 & 99.6 & 94.0 & 79.5 & 49.9 \\
\hline
\end{tabular}

\section{Results of Bathymetric Surveys}

The site-specific results for each bridge are discussed in the following sections starting with the upstream-most bridge site and progressing downstream, followed by a discussion of general findings that are not site specific. The range of bed elevations described as "the channel-bed elevations" for each bridge were based upon statistical analysis of the bathymetry data at each bridge, and covers the percentile range from 5 to 95 percent of the data. All elevation data were referenced to the North American Vertical Datum of 1988 (NAVD 88). The difference between NAVD 88 and the National Geodetic Vertical Datum of 1929 (NGVD 29) used in MoDOT bridge plans ranged from -0.21 to $0.16 \mathrm{ft}$ (NAVD 88 minus NGVD 29) throughout the St. Louis area, with an average value of $-0.09 \mathrm{ft}$.

At 3 of the 12 bridges, a Level II scour assessment (Lagasse and others, 1991) was performed in November 2002 (Huizinga and Rydlund, 2004), and a Level II scour assessment of structure A1500 was performed in August 2010 (Richard Huizinga, unpub. data, 2010). A Level II scour assessment is an application of hydrologic, hydraulic, and sediment transport concepts to determine qualitative scour-depth estimates, and includes obtaining the cross section of the channel on the downstream side of the bridge. The surveyed channel bed from this study was compared to the channel bed at the time of the Level II assessments in 2002 or 2010, where applicable. 


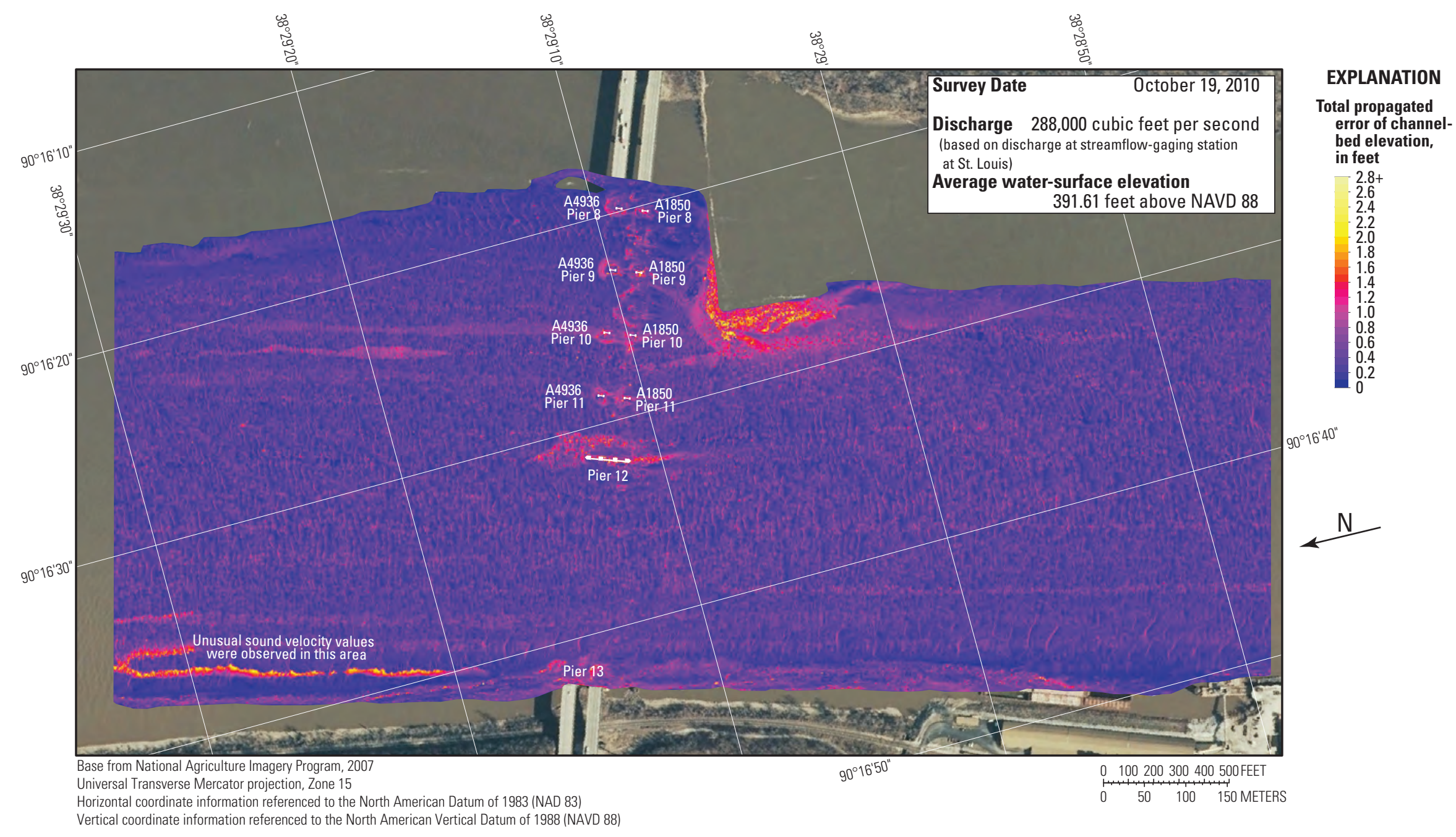

Figure 3. Total propagated error of bathymetric data from the Mississippi River channel in the vicinity of structures A4936 and A1850 on Interstate 255 near St. Louis, Missouri. 


\section{Structures A4017 and J1000 on U.S. Highway 40}

Structures A4017 and J1000 are dual bridges on U.S. Highway 40 on the northwestern side of the St. Louis metropolitan area, between Chesterfield and Weldon Spring, Missouri (figs. 1, 4). The survey was conducted on October 18, 2010; the average water-surface elevation of the river in the survey area determined by the RTK GPS tide solution was $444.20 \mathrm{ft}$ (table 5). Flow on the Missouri River was about $95,300 \mathrm{ft}^{3} / \mathrm{s}$ during the survey (table 5).

The survey area was about 4,250 ft long and about $1,080 \mathrm{ft}$ wide, extending from L-head dikes on one bank to shallow areas on the other in the main channel (figs. 4, 5). The upstream end of the survey area was about 1,620 ft upstream from the centerline of structures A4017 and J1000 (figs. $4,5)$. The channel-bed elevations ranged from about 414 to
$430 \mathrm{ft}$ for most of the surveyed area (5 to 95 percentile range of the bathymetric data), except near the main channel piers of structures A4017 and J1000, and near the ends of various spur dikes (fig. 5), especially near the left main channel piers (fig. 6). A thalweg on the right (south) bank on the upstream end of the surveyed area was about $5 \mathrm{ft}$ deeper than the channel bed in the middle of the channel (fig. 5). The thalweg became shallower and shifted to the middle of the channel at the bridges, and continued to shift to the left side and became deeper downstream from the bridges (fig. 5). Medium dunes and ripples were detected in the middle of the channel, with small dunes and ripples being detected in the shallow areas between spur dikes and on the left side of the channel in the upstream reach (fig. 5). A rock outcrop is present on the left (north) bank in the reach downstream from the bridges (fig. 5).

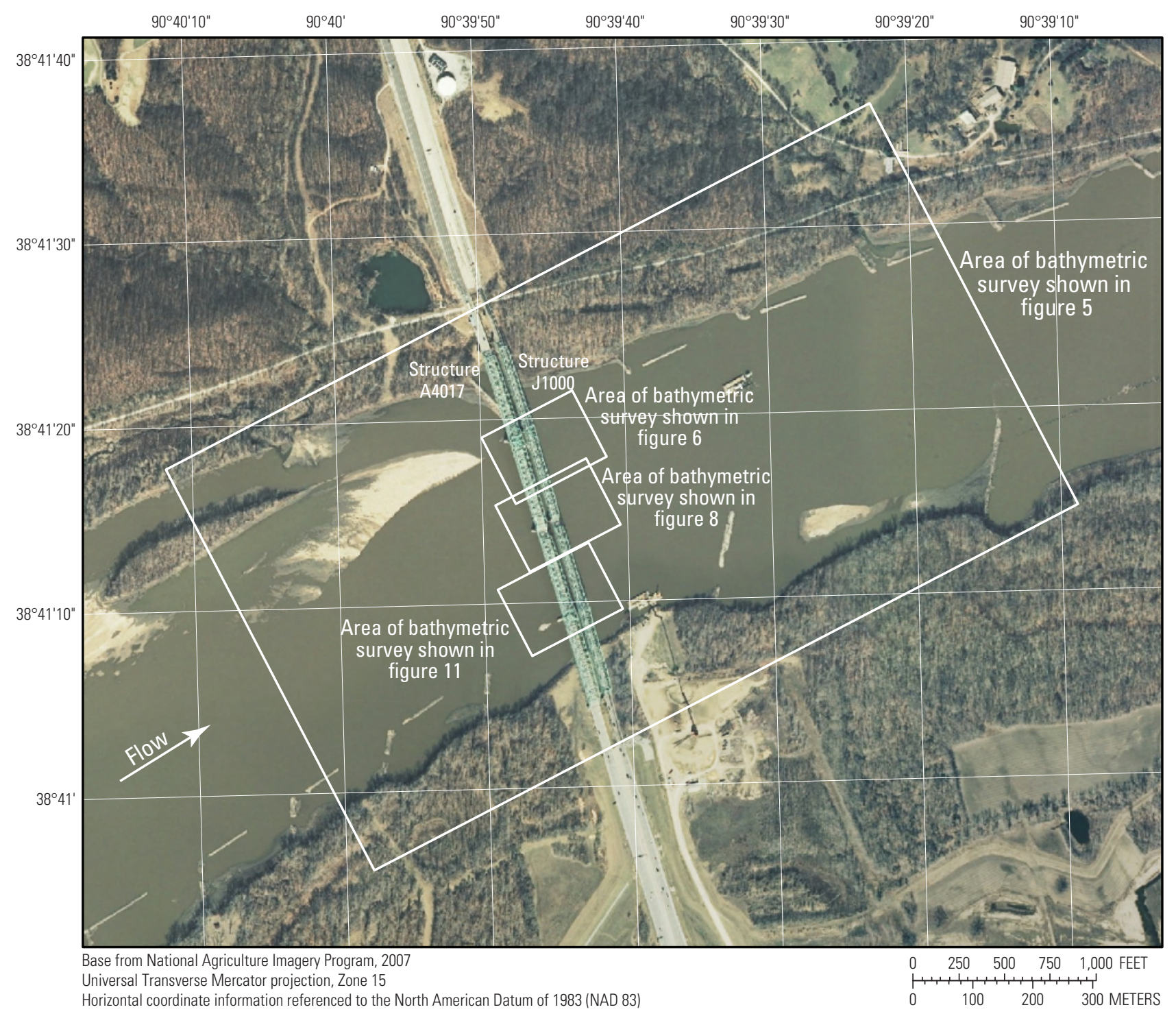

Figure 4. Location of the bathymetric survey area on the Missouri River near structures A4017 and J1000 on U.S. Highway 40 near St. Louis, Missouri. 


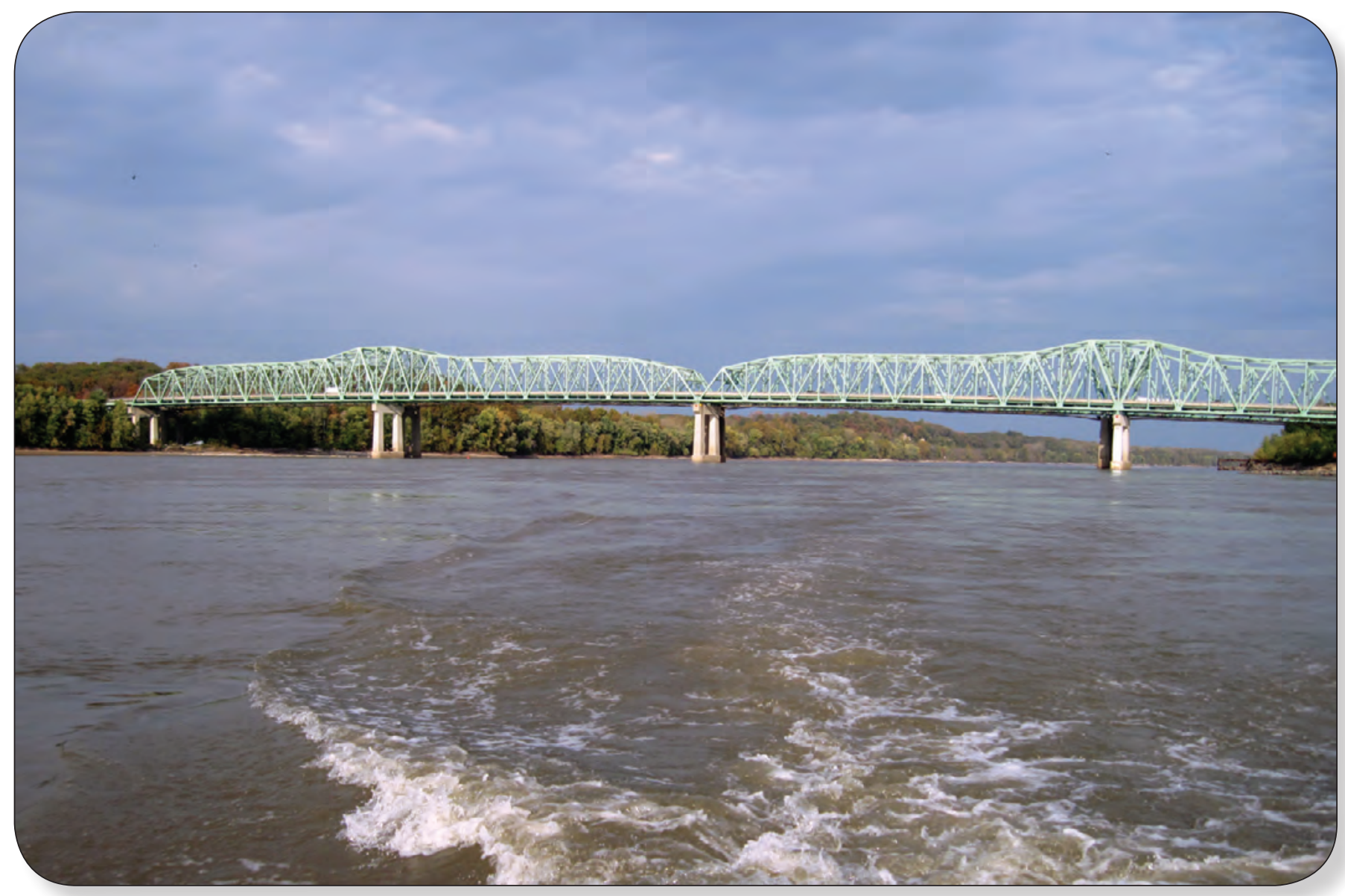

Structures A4017 and J1000 on U.S. Highway 40. Structure A4017 is in the foreground and J1000 is in the background.

Table 5. Bridge and survey information, and minimum elevation in the channel from surveys on the Missouri and Mississippi Rivers near St. Louis, Missouri, from October 18-25, 2010.

[MoDOT, Missouri Department of Transportation; $\mathrm{ft}^{3} / \mathrm{s}$, cubic feet per second; ft, feet; US, United States highway; MO, Missouri State highway; IS, Interstate highway; E, Eastbound; W, Westbound; all elevations are in feet above the North American Vertical Datum of 1988]

\begin{tabular}{lllcccc}
\hline $\begin{array}{c}\text { MoD0T structure } \\
\text { number } \\
\text { (fig. 1) }\end{array}$ & Survey date & Route & River mile & $\begin{array}{c}\text { Discharge } \\
\text { (ft } \mathbf{s}^{\mathbf{s})}\end{array}$ & $\begin{array}{c}\text { Average water-surface } \\
\text { elevation in vicinity of } \\
\text { bridge } \\
\text { (ft) }\end{array}$ & $\begin{array}{c}\text { Approximate minimum } \\
\text { channel elevation } \\
\text { (ft) }\end{array}$ \\
\hline A4017/J1000 & $10 / 18 / 10$ & US 40 & 43.9 & ${ }^{b} 95,300$ & 444.20 & 415 \\
A5585 E \& W & $10 / 21 / 10$ & MO 364 & 32.7 & ${ }^{b} 91,600$ & 431.99 & 400 \\
A3292/L0561 & $10 / 21 / 10$ & IS 70 & 29.6 & ${ }^{b} 91,600$ & 430.02 & 402 \\
A4557 E \& W & $10 / 22 / 10$ & MO 370 & 27.0 & ${ }^{b} 90,000$ & 428.41 & 395 \\
A3047 & $10 / 25 / 10$ & US 67 & 8.1 & ${ }^{b} 87,400$ & 410.19 & 377 \\
A1500 & $10 / 20 / 10$ & IS 55 & 179.2 & ${ }^{c} 277,000$ & 396.54 & 321 \\
A4936/A1850 & $10 / 19 / 10$ & IS 255 & 168.8 & ${ }^{c} 288,000$ & 391.61 & 323 \\
\hline
\end{tabular}

${ }^{a}$ The minimum channel elevation excluding scour holes near the bridge, typically in the channel thalweg.

${ }^{b}$ Discharge at the streamflow-gaging station on the Missouri River at St. Charles, Missouri (station 06935965) at the time of the survey.

${ }^{c}$ Discharge at the streamflow-gaging station on the Mississippi River at St. Louis, Missouri (station 07010000) at the time of the survey. 


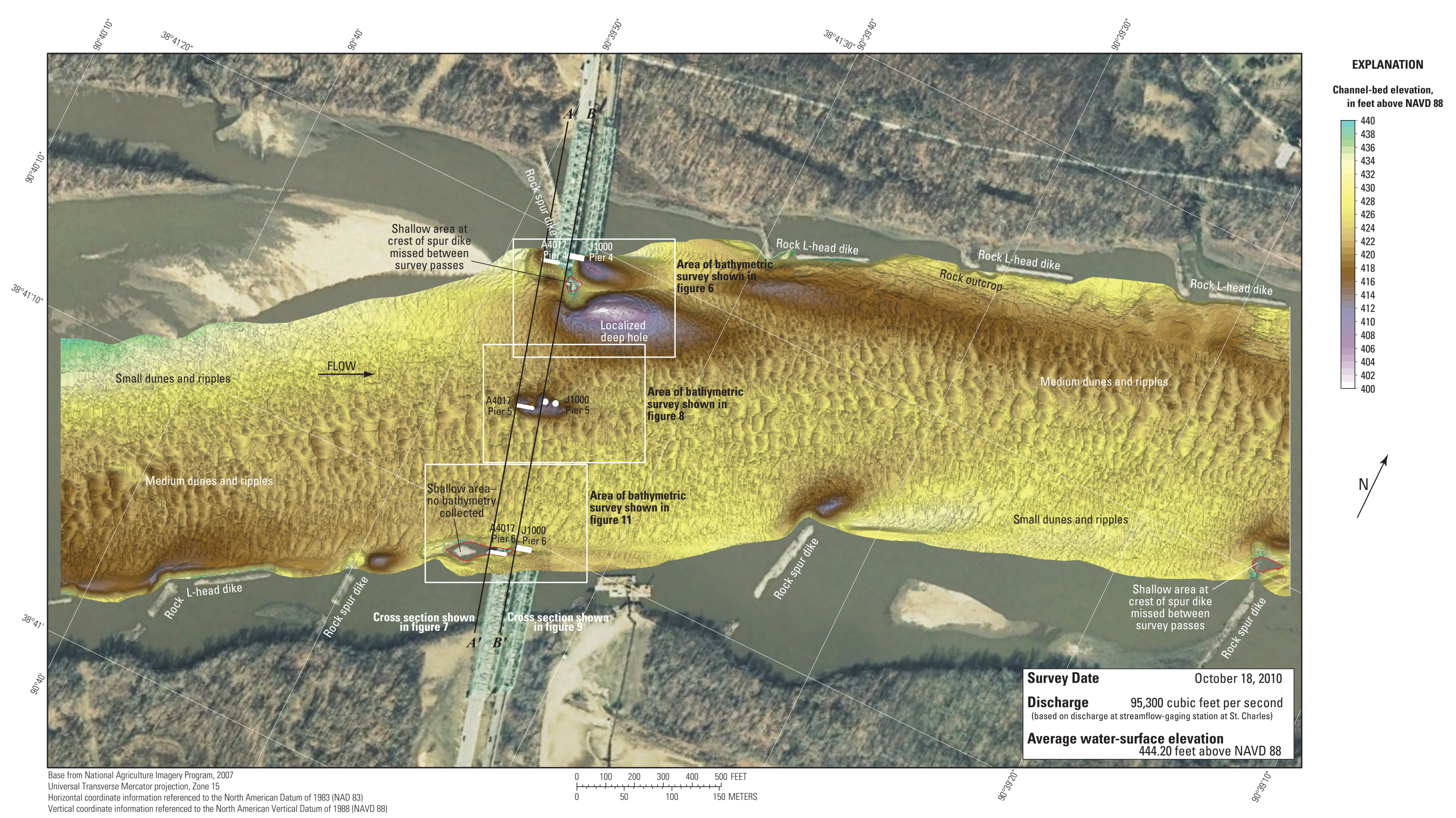

Figure 5. Bathymetric survey of the Missouri River channel in the vicinity of structures A4017 and J1000 on U.S. Highway 40 near St. Louis, Missouri. 
In the vicinity of the left main channel piers (pier 4 at both structures, fig. 6), a localized deep scour hole at the end of the spur dike had a minimum elevation of about $400 \mathrm{ft}$. A substantial debris raft at the nose of pier 4 of downstream structure J1000 and the presence of the spur dike made it impossible to acquire bathymetry data in the area upstream from that pier. At the upstream nose of pier 4 of upstream structure A4017, a local scour hole had a minimum elevation of approximately $416 \mathrm{ft}$ (table 6), about $14 \mathrm{ft}$ below the average channel bed immediately upstream from the pier, but well above the bottom of the footing elevation of $405.10 \mathrm{ft}$ (fig. 7). Downstream from pier 4 of downstream structure J1000, another localized deep scour hole had a minimum elevation of about $406 \mathrm{ft}$ (fig. 6), which exposes the downstream right corner of the caisson of that pier. Information from bridge plans indicates that pier 4 of structure A4017 is founded on footings on bedrock, with about $13 \mathrm{ft}$ of bed material between the bottom of the upstream scour hole and bedrock at the upstream pier (fig. 7; table 6). Pier 4 of structure J1000 is founded on a caisson on bedrock, and the bottom of the local scour hole downstream from this pier is only about $2 \mathrm{ft}$ above the bottom of the caisson and bedrock (table 6). However, the local scour hole likely is the result of flow over the spur dike, and not directly caused by the pier, and the downstream pier essentially is embedded in the rock of the dike, which will limit or prevent additional scour near both left main channel piers and minimize the effect of the local scour hole on the stability of the piers.

In the vicinity of the central main channel piers (pier 5 at both structures, fig. 8), a local scour hole had a minimum elevation of approximately $408 \mathrm{ft}$ (table 6), about $14 \mathrm{ft}$ below the average channel bed immediately upstream from the piers, but well above the bottom of the seal course elevation (383 ft) of the upstream pier (figs. 7, 9; table 6); however, the local scour hole has exposed the upper part of the caissons of the downstream pier (figs. 8, 9). The central main channel piers were skewed to approach flow, which caused a wider scour hole with somewhat unique characteristics as compared to the scour hole of an unskewed pier. On the right (south) side of the upstream pier, the scour hole was slightly deeper, and extended beyond the downstream pier caissons, whereas the leeward left (north) side of both piers had a local ridge of deposition (fig. 8). The deposition downstream from the upstream pier was eroded by the scour hole that formed upstream from the downstream pier caissons (fig. 8). Information from bridge plans indicates that pier 5 of upstream structure A4017 is founded on shafts drilled $26 \mathrm{ft}$ into bedrock, with about $48 \mathrm{ft}$ of bed material between the bottom of the scour hole and bedrock (fig. 7; table 6). Pier 5 of structure $\mathrm{J} 1000$ is founded on caissons on bedrock, with about $41 \mathrm{ft}$ of bed material between the bottom of the scour hole and bedrock (fig. 9; table 6). A point cloud visualization of the multibeam depth points obtained during the survey clearly show the exposed caissons of the downstream pier (fig. 10).

In the vicinity of the right main channel piers (pier 6 at both structures, fig. 11), local scour was difficult to determine because a shallow area made it impossible to acquire bathymetry data immediately upstream from the piers. Deposition downstream from the upstream pier is eroded by scour action around the nose of the downstream pier (fig. 11), but the minimum elevation in the vicinity of the piers is no more than $4 \mathrm{ft}$ lower than the adjacent channel-bed elevation (figs. 9, 11). Information from bridge plans indicates that pier 6 of upstream structure A4017 is founded on shafts drilled $13 \mathrm{ft}$ into bedrock (fig. 7; table 6), whereas pier 6 of structure $\mathrm{J} 1000$ is founded on caissons on bedrock, with about $64 \mathrm{ft}$ of bed material between the bottom of the scour hole and bedrock (fig. 9; table 6).

The surveyed bed is approximately $10 \mathrm{ft}$ lower than the original ground line from bridge plans at the time of construction (1985) at upstream structure A4017 between the central and right main channel piers (piers 5 and 6; fig. 7). The surveyed bed is approximately $16 \mathrm{ft}$ lower than the original ground line from bridge plans at construction (1935) at downstream structure J1000 throughout much of the channel (fig. 9). These changes in bed elevation indicate a decrease in the overall bed elevation at this site with time. 


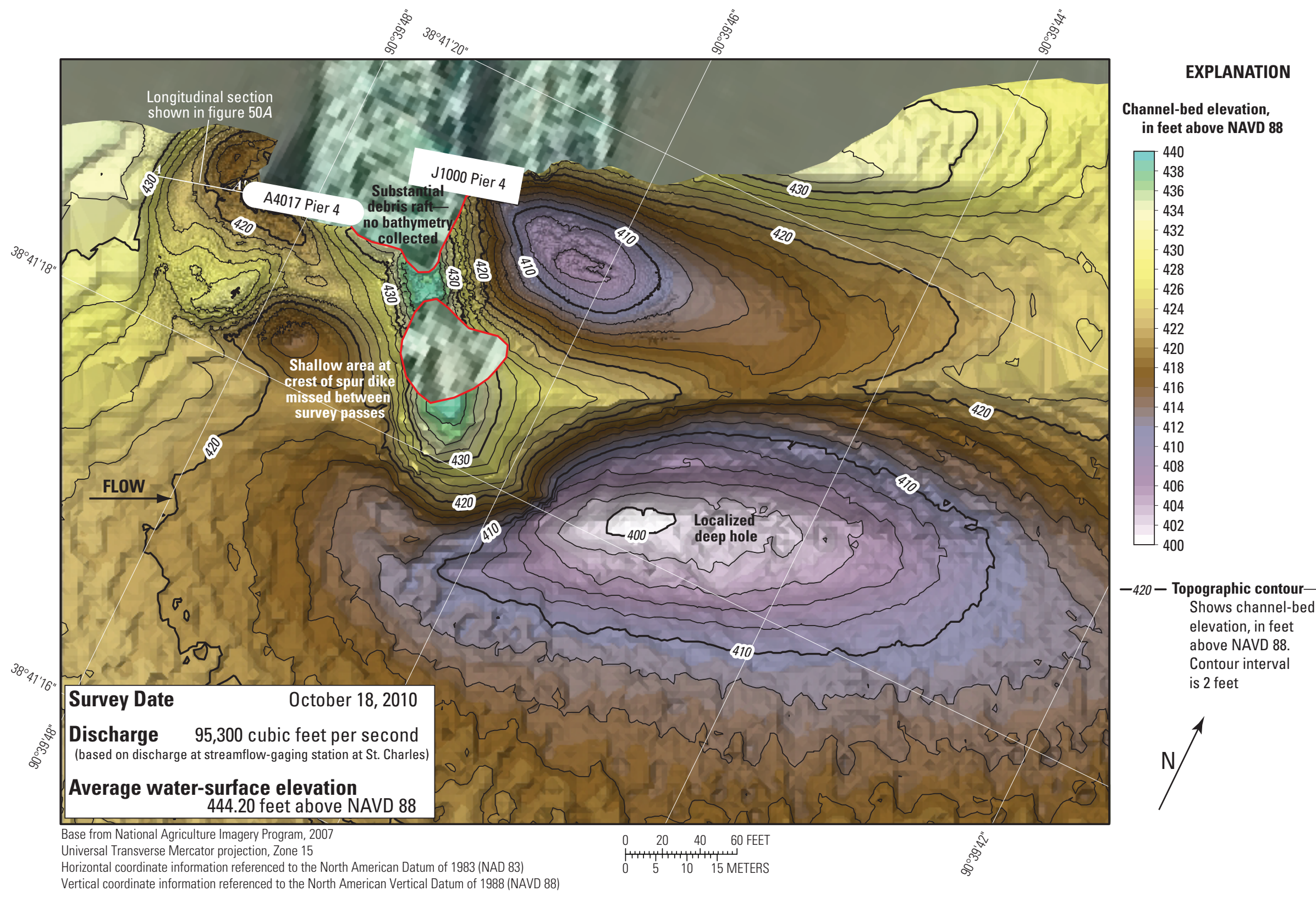

Figure 6. Bathymetric survey of the Missouri River channel in the vicinity of the left main channel piers of structures A4017 and J1000 on U.S. Highway 40 near St. Louis, Missouri. 
Table 6. Results near piers from surveys on the Missouri River near St. Louis, Missouri, from October 18-25, 2010.

[MoDOT, Missouri Department of Transportation; ft, feet; --, not known/applicable; all elevations are in feet above the North American Vertical Datum of 1988]

\begin{tabular}{|c|c|c|c|c|c|c|c|c|c|c|c|}
\hline \multirow[b]{2}{*}{$\begin{array}{c}\text { MoDOT } \\
\text { structure } \\
\text { number } \\
\text { (fig. 1) }\end{array}$} & \multirow[b]{2}{*}{$\begin{array}{l}\text { MoDOT } \\
\text { pier } \\
\text { number }\end{array}$} & \multicolumn{4}{|c|}{ Foundation information } & \multirow{2}{*}{$\begin{array}{l}\text { Approximate } \\
\text { minimum } \\
\text { elevation in } \\
\text { scour hole } \\
\text { near pier }{ }^{\text {a }} \\
\text { (ft) }\end{array}$} & \multirow{2}{*}{$\begin{array}{l}\text { Approximate } \\
\text { elevation of } \\
\text { scour hole at } \\
\text { upstream pier } \\
\text { face } \\
\text { (ft) }\end{array}$} & \multirow[b]{2}{*}{$\begin{array}{c}\text { Approximate } \\
\text { elevation of } \\
\text { bedrock near } \\
\text { pier } \\
\text { (ft) }\end{array}$} & \multirow{2}{*}{$\begin{array}{l}\text { Approximate } \\
\text { distance be- } \\
\text { tween bottom } \\
\text { of scour hole } \\
\text { and bedrock } \\
\text { (ft) }\end{array}$} & \multirow{2}{*}{$\begin{array}{c}\text { Depth } \\
\text { of scour } \\
\text { hole from } \\
\text { upstream } \\
\text { channel bed } \\
\text { (ft) }\end{array}$} & \multirow[b]{2}{*}{$\begin{array}{c}\text { Approximate } \\
\text { frontal slope } \\
\text { of scour hole } \\
\text { (ft/ft) }\end{array}$} \\
\hline & & Type & $\begin{array}{c}\text { Width } \\
\text { (ft) }\end{array}$ & $\begin{array}{l}\text { Penetration } \\
\text { into bedrock } \\
\text { (ft) }\end{array}$ & $\begin{array}{c}\text { Seal course } \\
\text { bottom } \\
\text { elevation } \\
\text { (ft) }\end{array}$ & & & & & & \\
\hline \multirow[t]{3}{*}{ A4017 } & 4 & Footing & 32 & 1 & -- & 416 & 418 & 405 & 13 & 14 & b 1.82 \\
\hline & 5 & Drilled shaft & 24 & 26 & 383.00 & 410 & 416 & 368 & 48 & 7 & 1.89 \\
\hline & 6 & Drilled shaft & 28 & 13 & 390.00 & 424 & $--^{c}$ & 360 & 64 & $--^{c}$ & $--^{c}$ \\
\hline \multirow[t]{3}{*}{$\mathrm{J} 1000$} & 4 & Caisson & 20 & 1 & -- & d 406 & $--^{c}$ & 404 & 2 & $--^{c}$ & $--^{c}$ \\
\hline & 5 & Caisson & 22 & 1 & -- & 408 & 408 & 367 & 41 & 14 & 1.78 \\
\hline & 6 & Caisson & 19.5 & 1 & -- & 421 & 424 & 360 & 64 & 4 & 2.02 \\
\hline \multirow[t]{3}{*}{ A5585 Eastbound } & 5 & Drilled shaft & 32.9 & 11 & 371.62 & 405 & 405 & 372 & 33 & 6 & 1.78 \\
\hline & 6 & Drilled shaft & 33.5 & 11 & 371.62 & 408 & 408 & 358 & 50 & 8 & 1.74 \\
\hline & 7 & Drilled shaft & 33.5 & 11 & 371.62 & 418 & 418 & 351 & 67 & 7 & 1.77 \\
\hline \multirow[t]{3}{*}{ A5585 Westbound } & 5 & Drilled shaft & 32.9 & 11 & 371.62 & 406 & 406 & 372 & 34 & 7 & 1.75 \\
\hline & 6 & Drilled shaft & 33.5 & 11 & 371.62 & 411 & 411 & 358 & 53 & 5 & 1.95 \\
\hline & 7 & Drilled shaft & 33.5 & 11 & 371.62 & 415 & 415 & 351 & 64 & 3 & 1.72 \\
\hline \multirow[t]{2}{*}{ A 3292} & 15 & Drilled shaft & 29.5 & 16 & 378.00 & 402 & $--^{c}$ & 350 & 52 & $--^{c}$ & $--^{c}$ \\
\hline & 16 & Drilled shaft & 29.5 & 17 & 378.00 & 402 & 402 & 342 & 60 & 8 & 2.05 \\
\hline \multirow[t]{2}{*}{ L0561 } & 16 & Caisson & 24 & 1 & -- & 410 & $--^{c}$ & 351 & 59 & $--^{c}$ & $--^{c}$ \\
\hline & 17 & Caisson & 24 & 3 & -- & 393 & 393 & 343 & 50 & 15 & 1.86 \\
\hline \multirow[t]{3}{*}{ A4557 Eastbound } & $2 \mathrm{C}$ & Drilled shaft & 24 & 15 & 386.00 & 403 & 403 & 358 & 45 & 4 & 2.00 \\
\hline & $3 \mathrm{C}$ & Drilled shaft & 24 & 15 & 388.00 & 400 & 400 & 353 & 47 & 7 & 2.42 \\
\hline & $4 \mathrm{C}$ & Drilled shaft & 24 & 15 & 394.00 & 412 & 412 & 345 & 67 & 0 & $--^{\mathrm{e}}$ \\
\hline \multirow[t]{3}{*}{ A4557 Westbound } & $2 \mathrm{C}$ & Drilled shaft & 24 & 15 & 386.00 & 401 & 401 & 358 & 43 & 6 & 1.90 \\
\hline & $3 \mathrm{C}$ & Drilled shaft & 24 & 15 & 388.00 & 402 & 402 & 353 & 49 & 4 & $--^{\mathrm{e}}$ \\
\hline & $4 \mathrm{C}$ & Drilled shaft & 24 & 15 & 394.00 & $\mathrm{~d} 403$ & $--^{c}$ & 345 & 58 & $--^{c}$ & $--^{c}$ \\
\hline \multirow[t]{3}{*}{ A 3047} & 10 & Drilled shaft & 26 & 13 & 346.50 & d 383 & 392 & 303 & 89 & 0 & $--^{d}$ \\
\hline & 11 & Drilled shaft & 26 & 15 & 346.50 & 380 & 380 & 314 & 66 & 11 & 1.77 \\
\hline & 12 & Drilled shaft & 26 & 26 & 359.00 & 392 & 392 & 336 & 56 & 5 & 1.70 \\
\hline
\end{tabular}

${ }^{a}$ The point of lowest elevation in the scour hole near the bridge pier, not necessarily at the upstream pier face.

${ }^{\mathrm{b}}$ Slope determined from upper part of scour hole, away from area affected by submerged object.

${ }^{c}$ Unable to determine because no bathymetry data were collected in this area.

${ }^{\mathrm{d}} \mathrm{Scour}$ hole at this pier is substantially affected by adjacent spur dike.

${ }^{\mathrm{e}}$ Unable to determine slope because no definitive scour hole was present. 


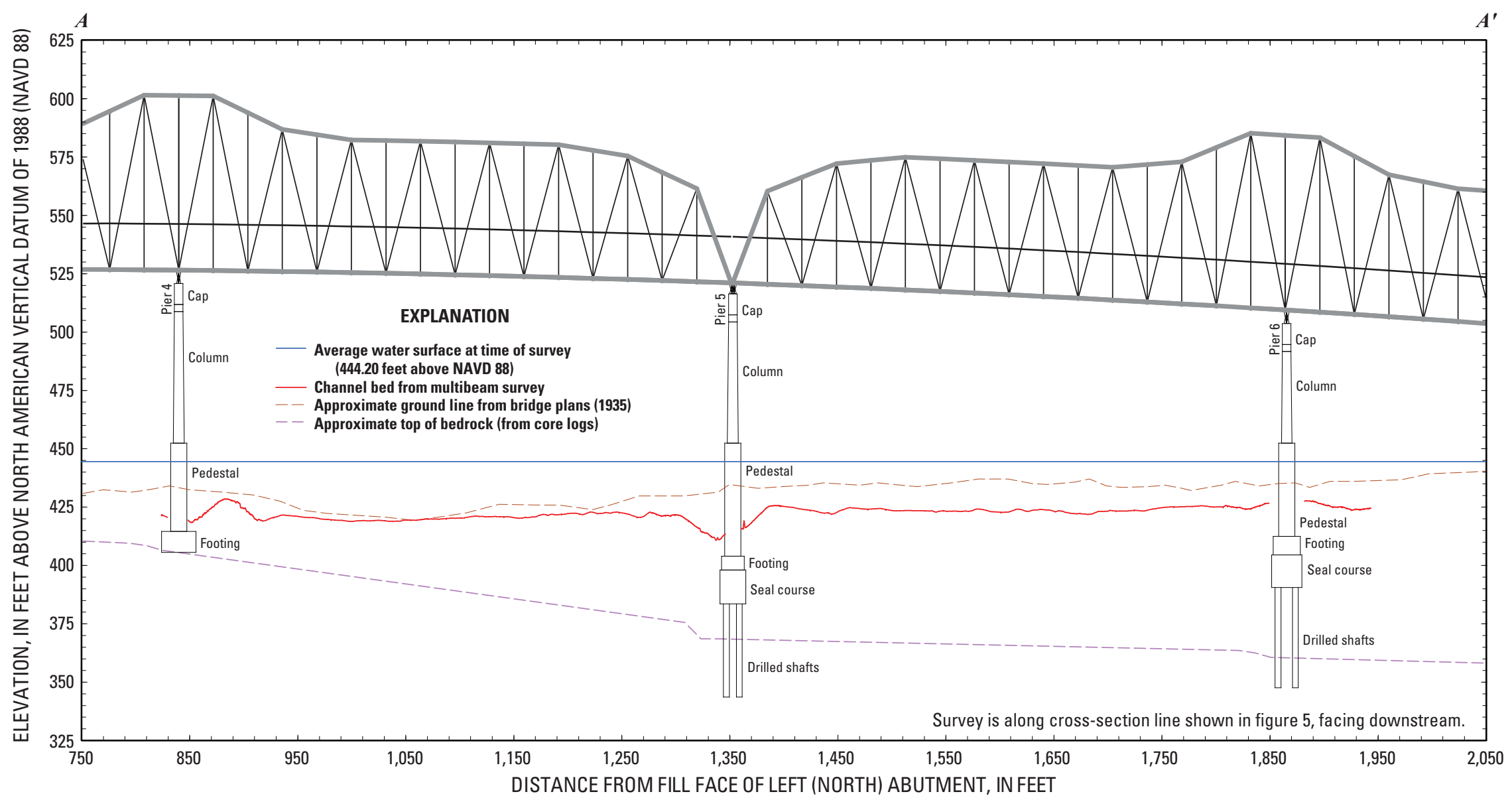

Figure 7. Key features, substructural and superstructural details, and surveyed channel bed of structure A4017 on U.S. Highway 40 over the Missouri River near St. Louis, Missouri. 


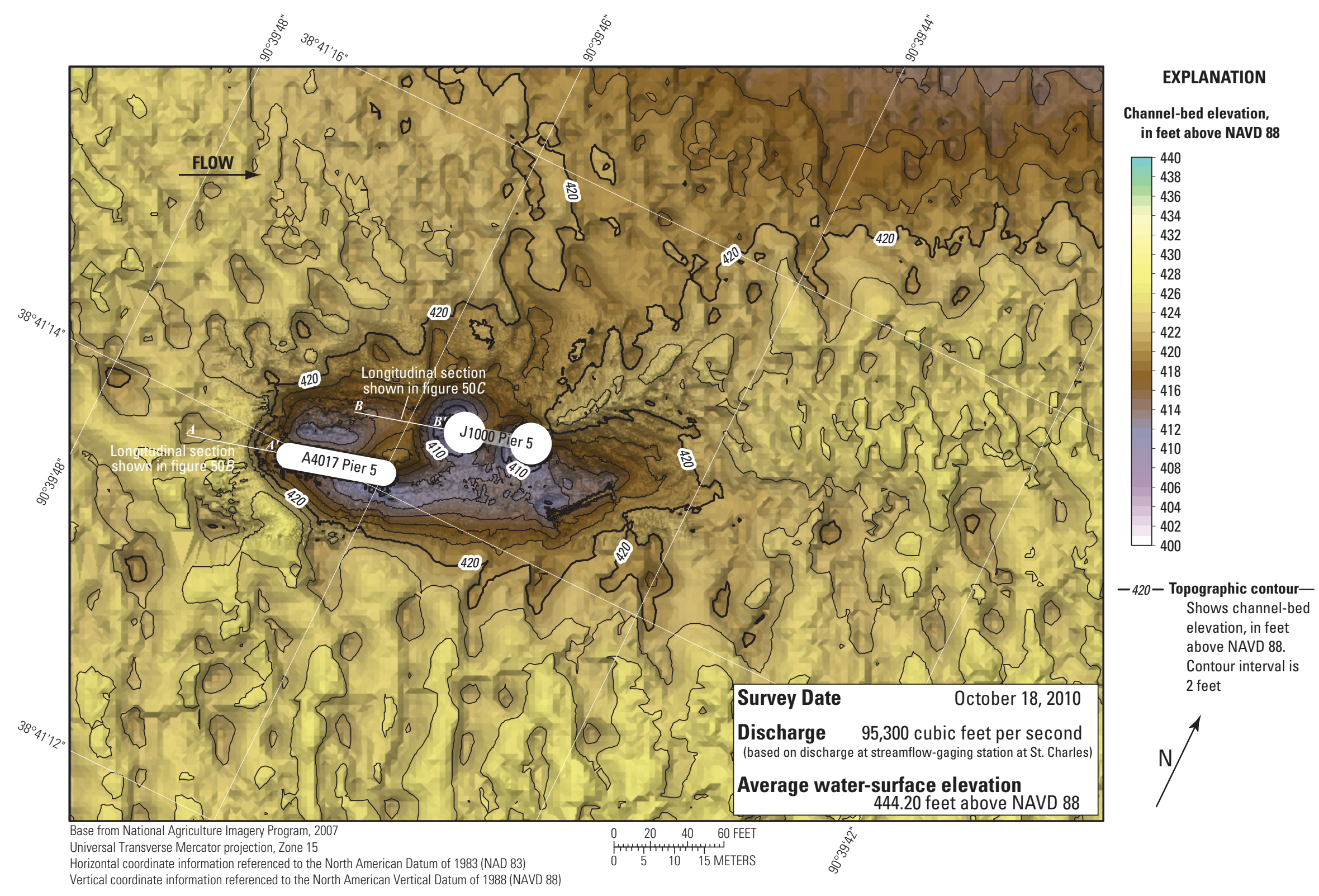

Figure 8. Bathymetric survey of the Missouri River channel in the vicinity of the central main channel piers of structures A4017 and J1000 on U.S. Highway 40 near St. Louis, Missouri. 


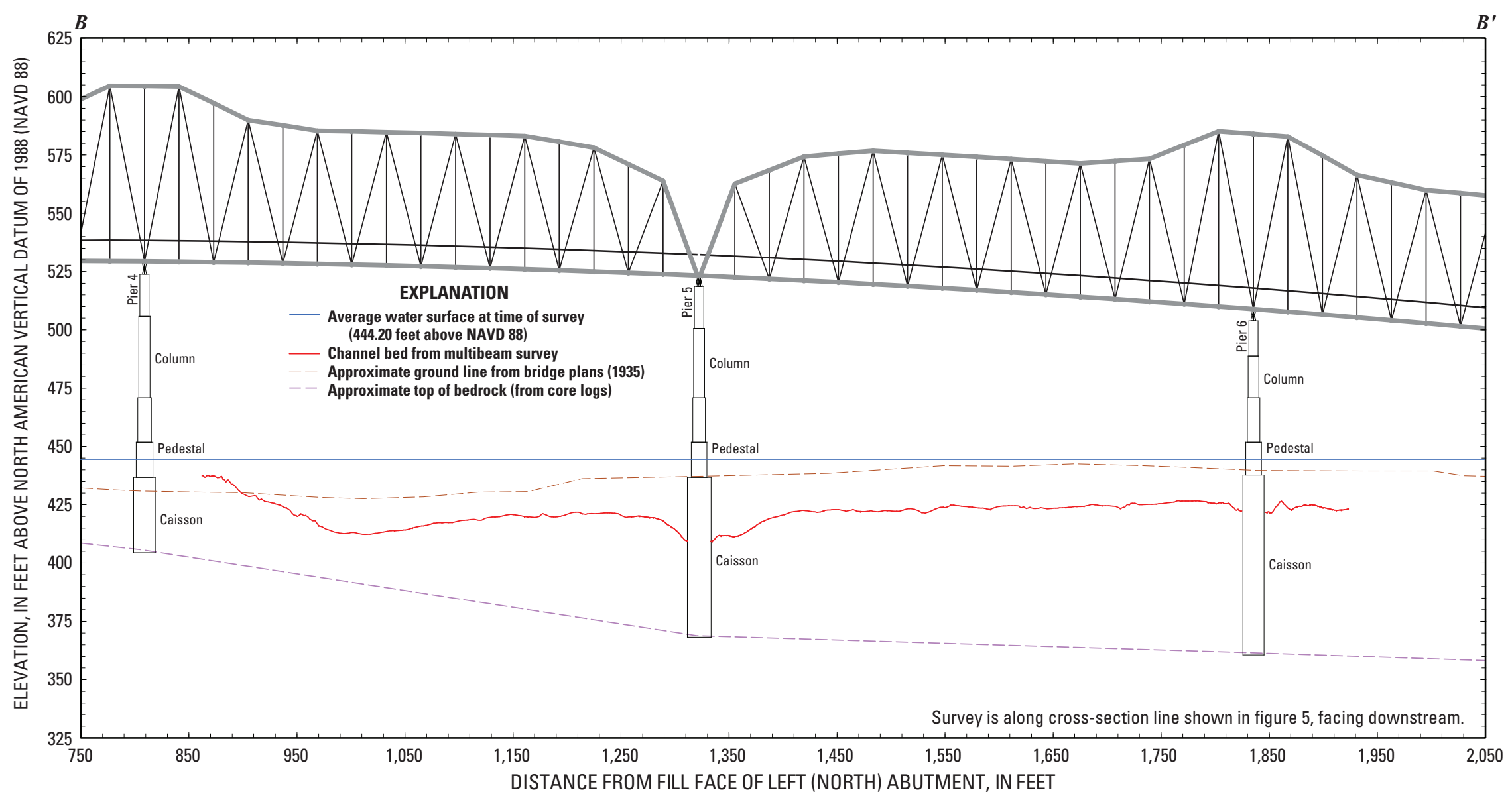

Figure 9. Key features, substructural and superstructural details, and surveyed channel bed of structure J1000 on U.S. Highway 40 over the Missouri River near St. Louis, Missouri.

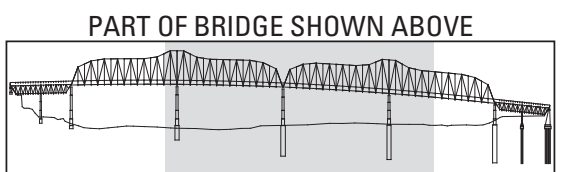




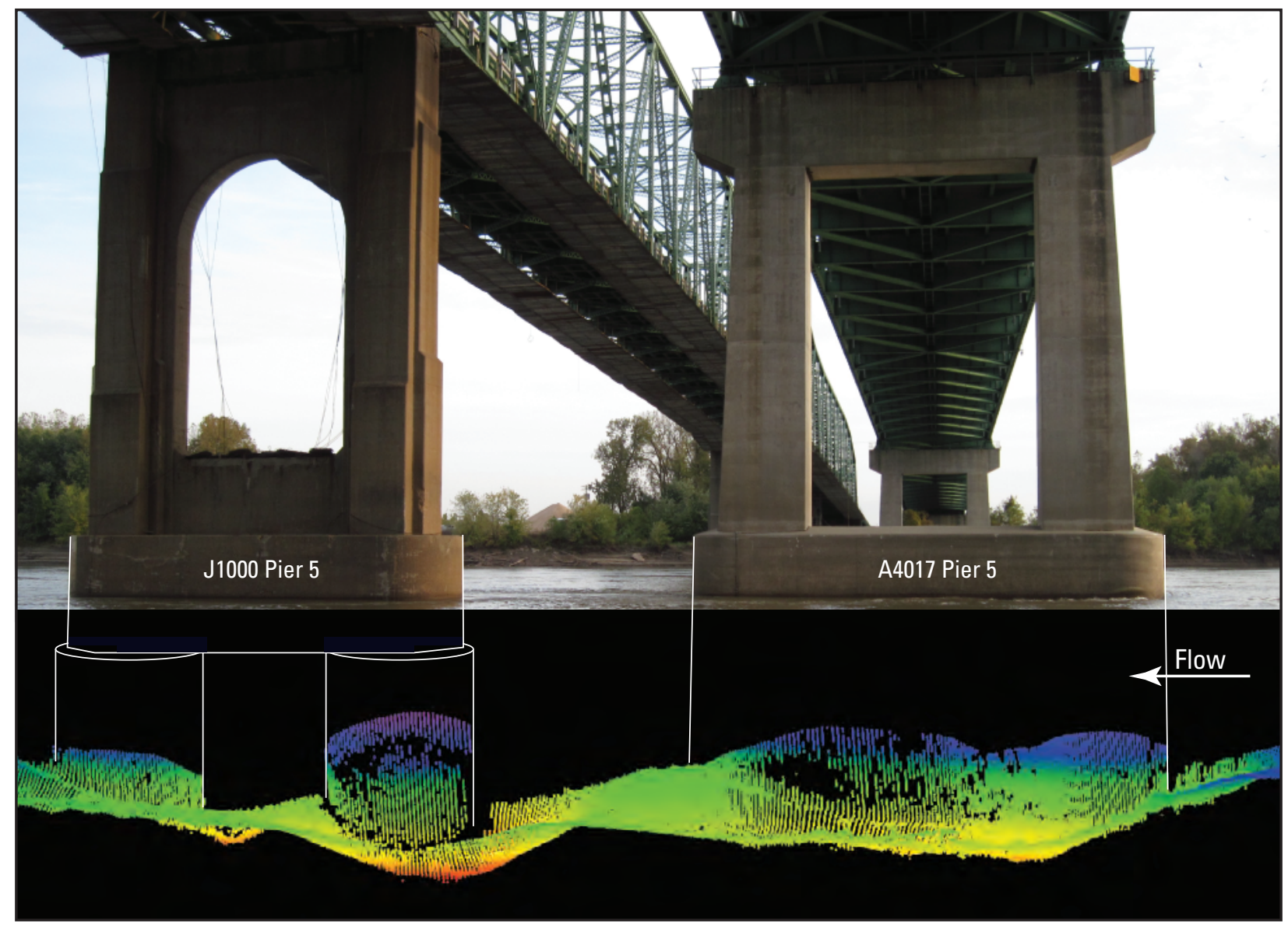

EXPLANATION

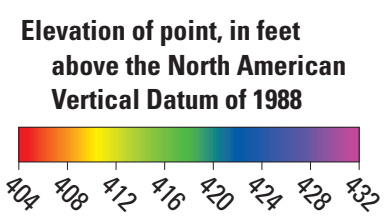

Figure 10. Point cloud visualization of the channel bed and left (north) side of the main channel piers (pier 5) of structures A4017 and J1000 on U.S. Highway 40 over the Missouri River near St. Louis, Missouri. 


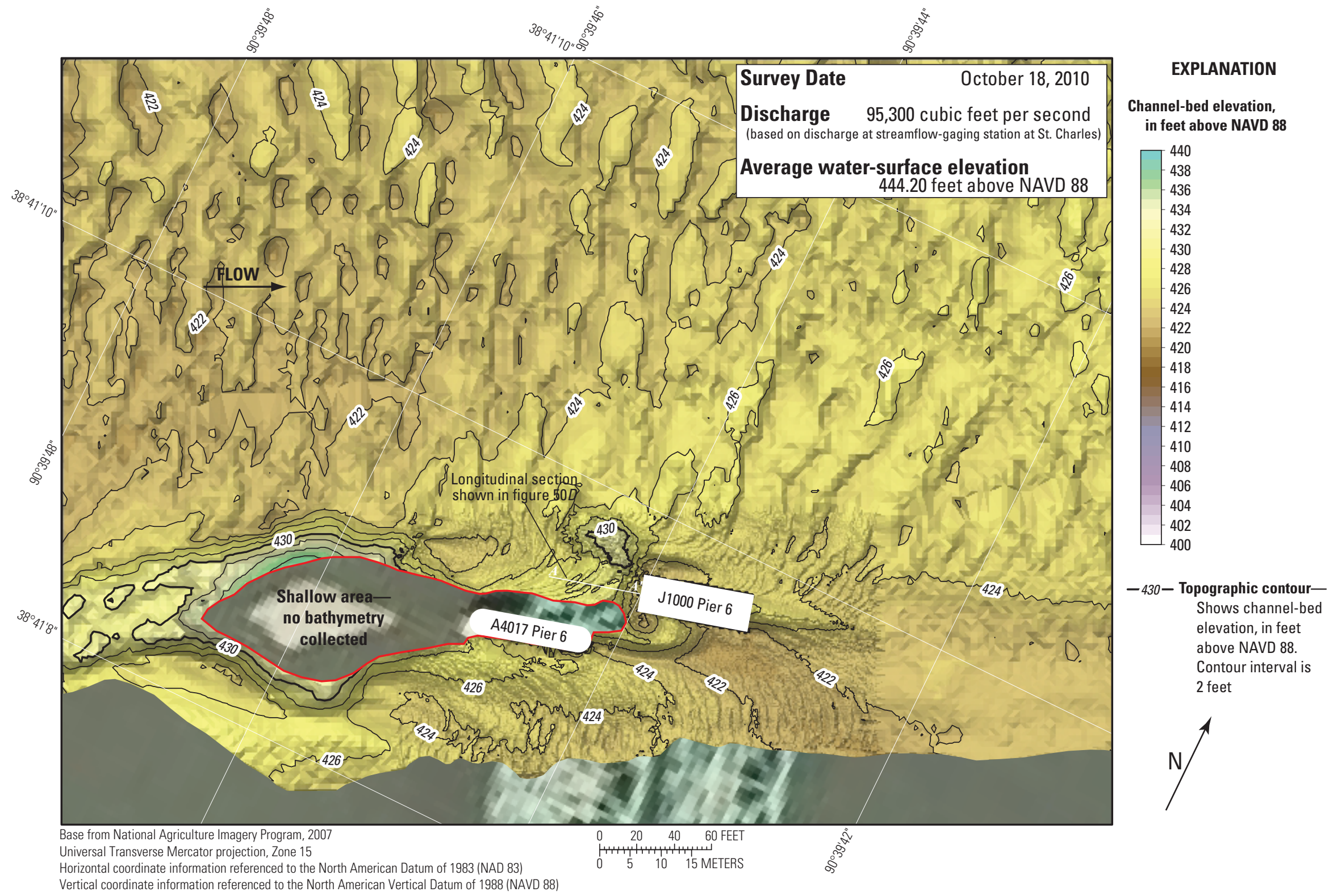

Figure 11. Bathymetric survey of the Missouri River channel in the vicinity of the right main channel piers of structures A4017 and J1000 on U.S. Highway 40 near St. Louis, Missouri. 


\section{Dual Bridge Structure A5585 on State Highway 364}

Structure A5585 consists of twin bridges on State Highway 364 on the northwestern side of the St. Louis metropolitan area, between Maryland Heights and St. Charles (figs. 1, 12). The survey was conducted on October 21, 2010, and the average water-surface elevation of the river in the survey area determined by the RTK GPS tide solution was 431.99 $\mathrm{ft}$ (table 5). Flow on the Missouri River was about 91,600 $\mathrm{ft}^{3} / \mathrm{s}$ during the survey (table 5).

The survey area was about 3,280 ft long and averaged about $880 \mathrm{ft}$ wide, extending from rock dikes and the channel bank on the left to shallow areas on the right in the main channel (fig. 13). The upstream end of the survey area was about 1,310 $\mathrm{ft}$ upstream from the centerline of structure A5585 (figs. 12, 13). The channel-bed elevations ranged from about 407 to $421 \mathrm{ft}$ for most of the surveyed area ( 5 to 95 percentile range of the bathymetric data), except for a shallow area in the upstream right part of the channel. A narrow thalweg along the outside of the river bend on the left (north) bank was about 5 to $10 \mathrm{ft}$ deeper than the channel bed in the middle of the channel (fig. 13). Between the rock spur dikes on the right (south) side of the channel, deposits reached an elevation of about $426 \mathrm{ft}$ (fig. 13). Dredging operations of a dredge barge moored downstream from the bridges caused several localized deep holes in the channel bed (fig. 13). A series of large dune features were detected in the left side of the middle of the channel, which appeared to be washing over the numerous medium and small dunes and ripples throughout the rest of the channel (fig. 13). A rock outcrop is present on the left (north) bank in the reach extending from upstream to just downstream from the bridges (fig. 13).

Scour holes were present in the vicinity of the main channel piers (fig. 14) of structure A5585, and generally there was more substantial scour associated with the upstream (eastbound) piers than the downstream (westbound) piers. The scour hole at upstream (eastbound) pier 5 had a minimum elevation of about $405 \mathrm{ft}$ (fig. 14; table 6), about $6 \mathrm{ft}$ below the average channel bed immediately upstream from the pier, whereas the scour hole at downstream (westbound) pier 5 had a minimum elevation of about $406 \mathrm{ft}$ (fig. 14; table 6), about $7 \mathrm{ft}$ below the average channel bed immediately upstream from the pier. The scour hole at upstream pier 6 had a minimum elevation of about $408 \mathrm{ft}$ (fig. 14; table 6), about $8 \mathrm{ft}$ below the average channel bed immediately upstream from the pier, whereas the scour hole at downstream pier 6 had a minimum elevation of about $411 \mathrm{ft}$ (fig. 14; table 6), about $5 \mathrm{ft}$ below the average channel bed immediately upstream from the pier. The scour hole at upstream pier 7 had a minimum elevation of about $418 \mathrm{ft}$ (fig. 14; table 6), about $7 \mathrm{ft}$ below the average channel bed immediately upstream from the pier, whereas the scour hole at downstream pier 7 had a minimum elevation of about $415 \mathrm{ft}$ (fig. 14; table 6), about $3 \mathrm{ft}$ below the average channel bed immediately upstream from the pier.

Information from bridge plans indicates that both bridges of structure A5585 are exactly the same in cross section for the part of the bridges across the main channel, which permits the cross-section data for each bridge to be examined together (fig. 15). The main channel piers of both bridges of structure A5585 are founded on shafts drilled $11 \mathrm{ft}$ into bedrock (fig. 15; table 6). Depth of bed material between bedrock and the bottom of the various scour holes at dual bridge structure A5585 ranges from 33 to $67 \mathrm{ft}$ because of the sloping bedrock in the area (fig. 15; table 6). The minimum elevation in each of the scour holes is substantially higher than the bottom of the seal course elevation at each pier of $371.62 \mathrm{ft}$ (fig. 15; table 6). The surveyed bed is not substantially different from the original ground line from bridge plans at the time of construction in 1994 (fig. 15).

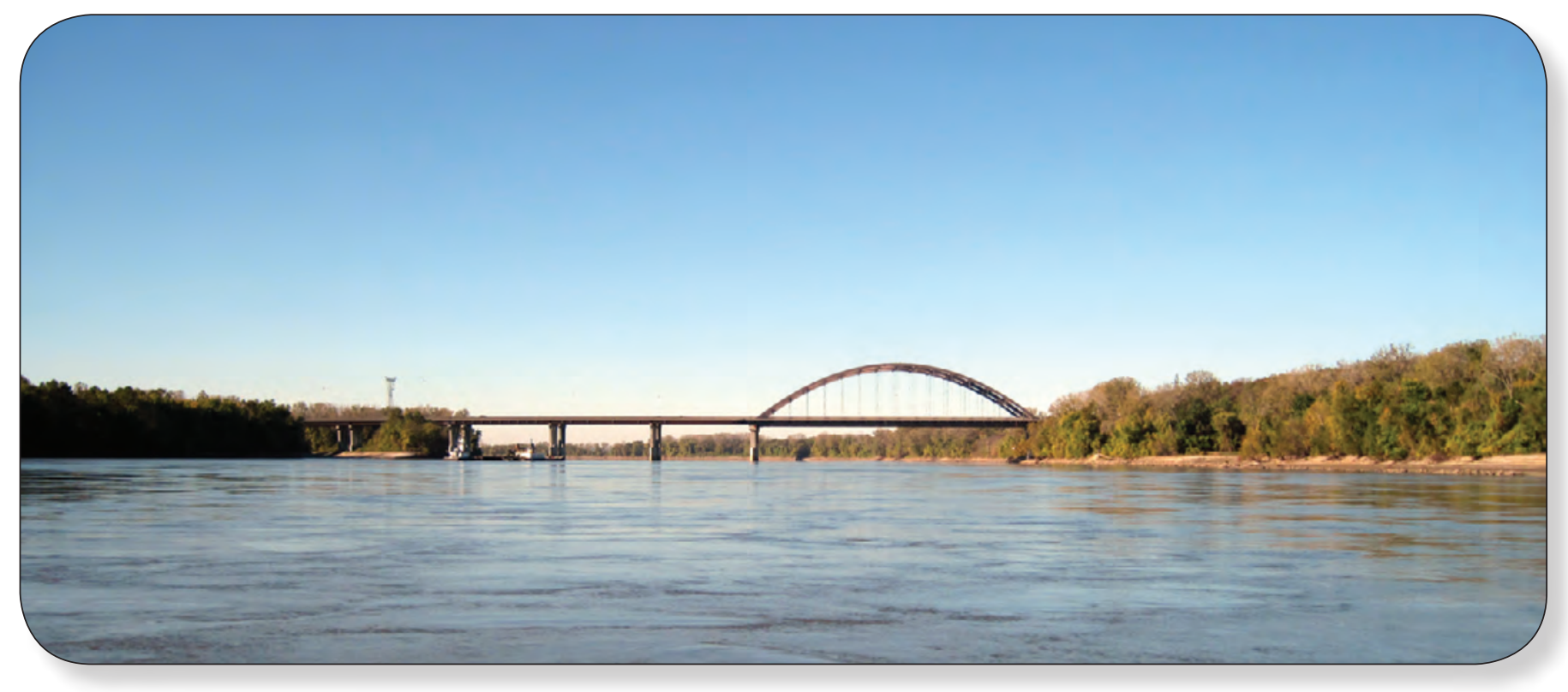

Dual bridge structure A5585 on State Highway 364. 


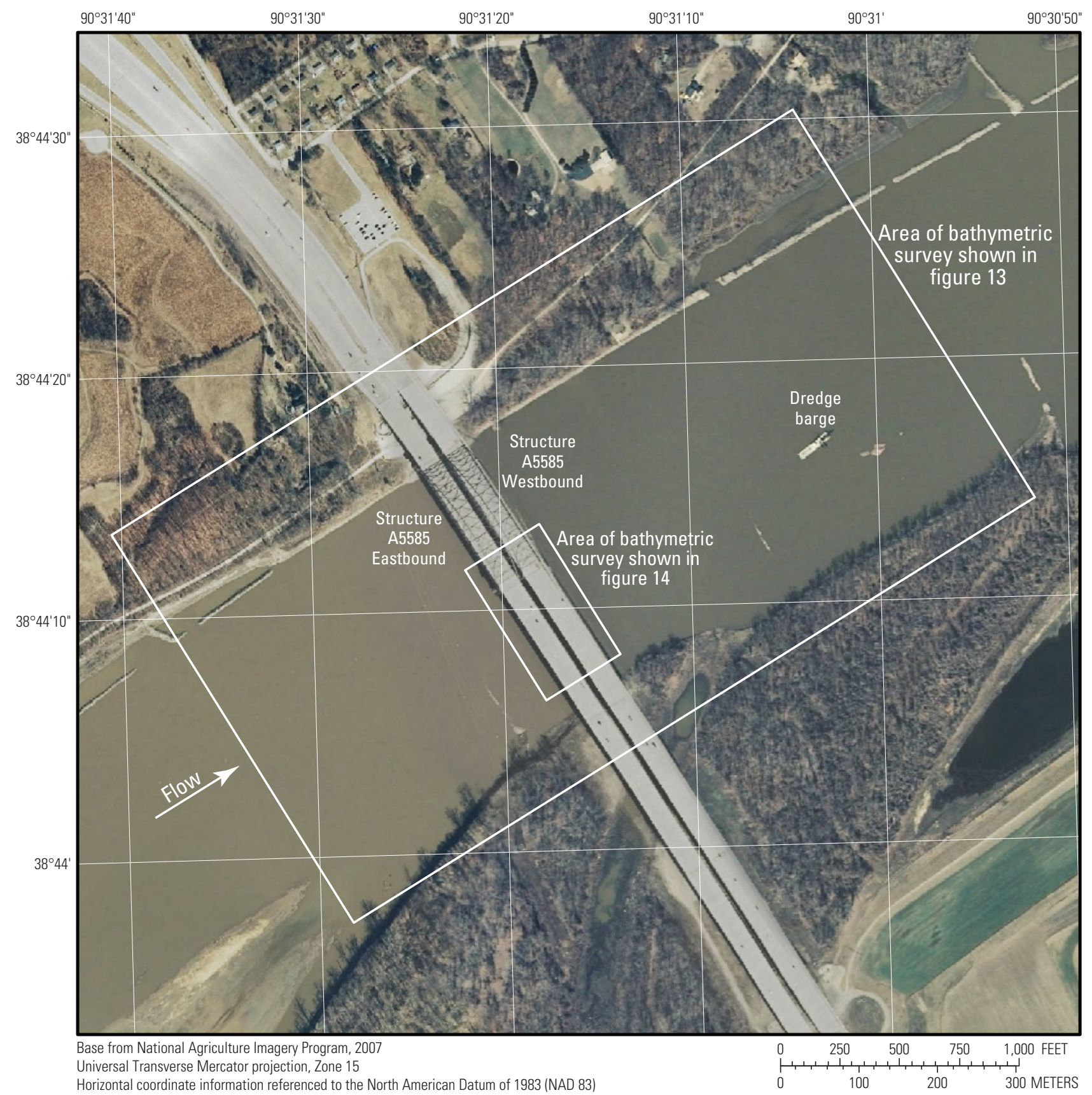

Figure 12. Location of the bathymetric survey area on the Missouri River near dual bridge structure A5585 on State Highway 364 near St. Louis, Missouri. 


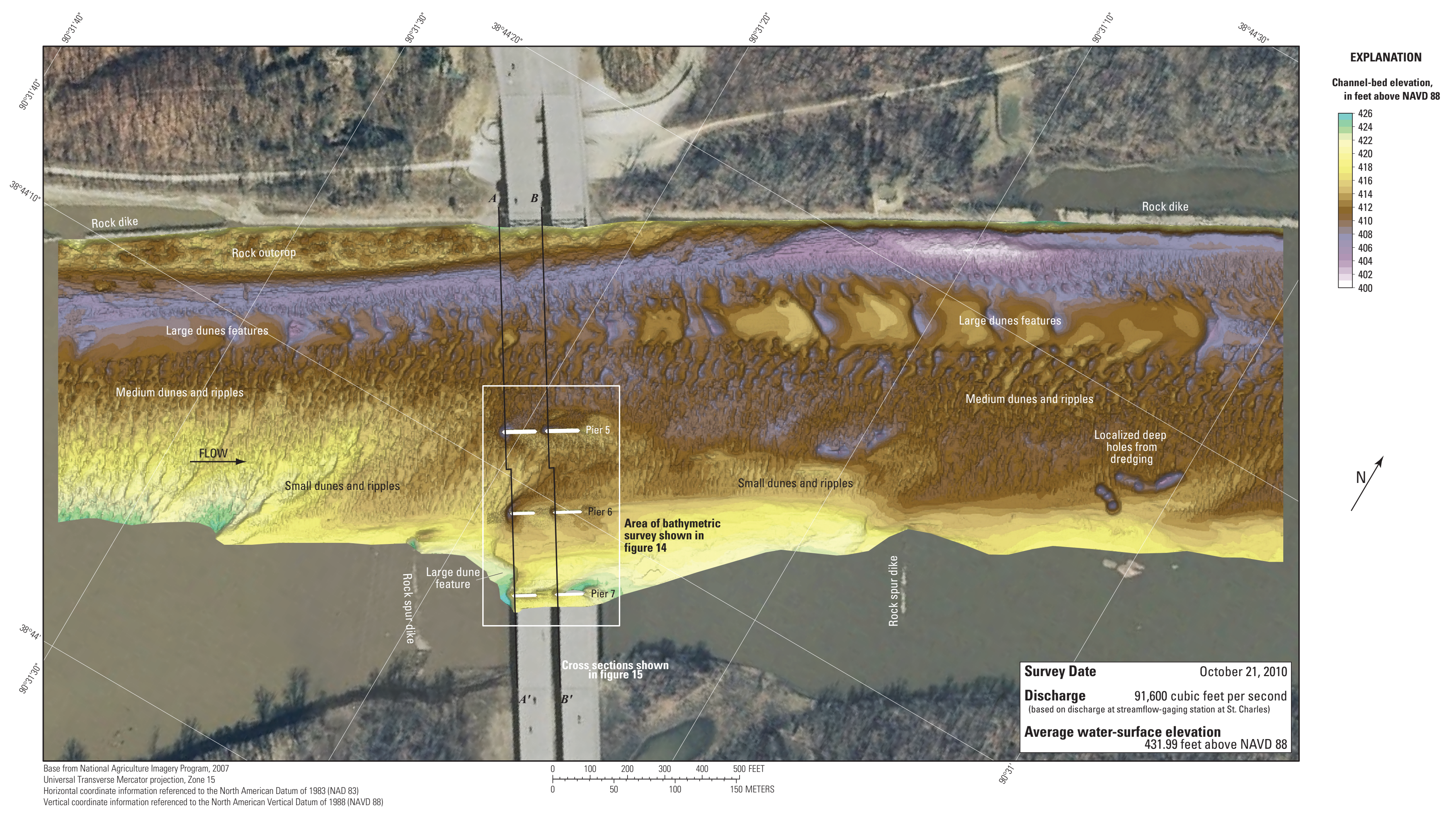

Figure 13. Bathymetric survey of the Missouri River channel in the vicinity of dual bridge structure A5585 on State Highway 364 near St. Louis, Missouri. 


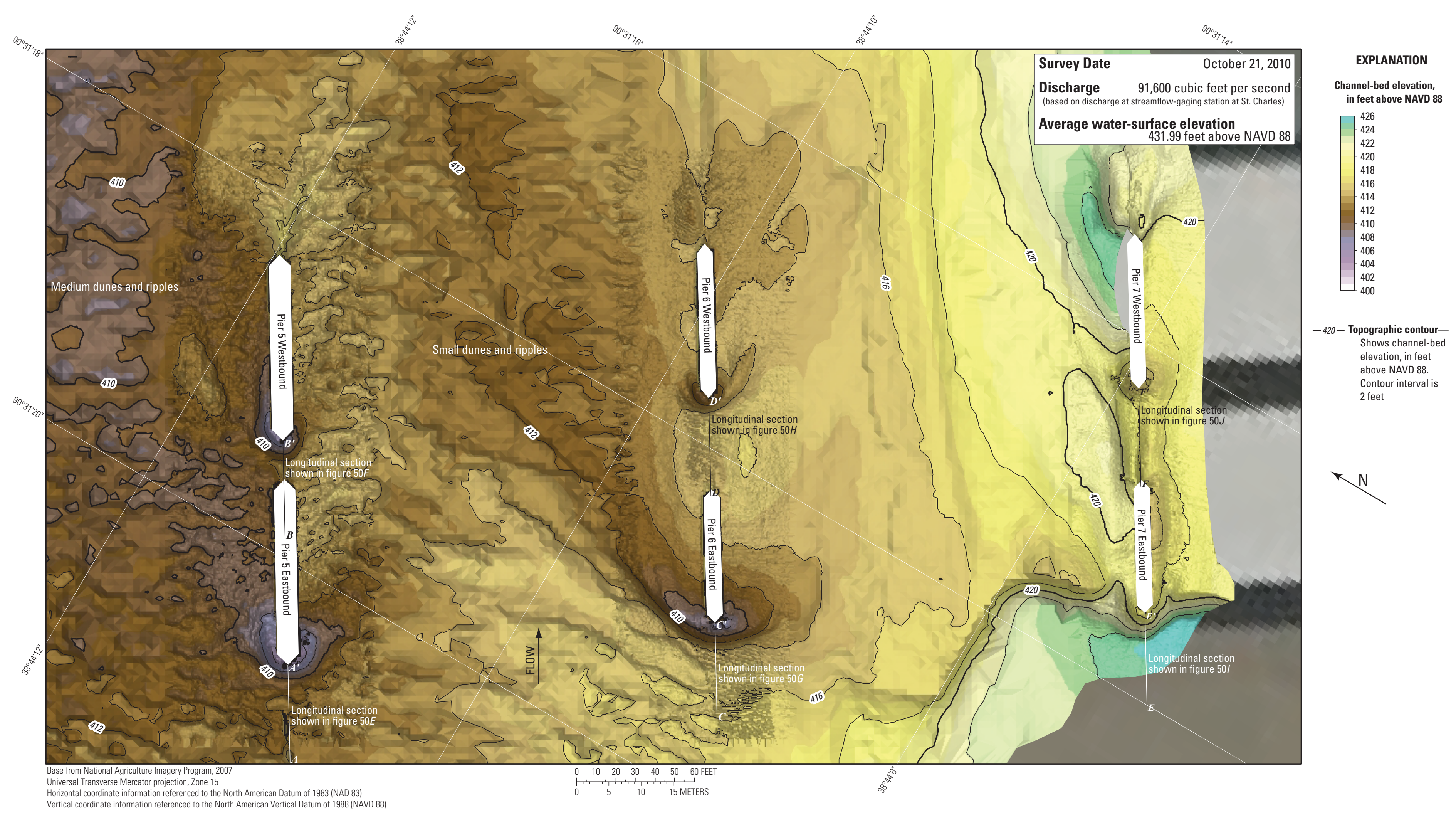

Figure 14. Bathymetric survey of the Missouri River channel in the vicinity of the main channel piers of dual bridge structure A5585 on State Highway 364 near St. Louis, Missouri. 

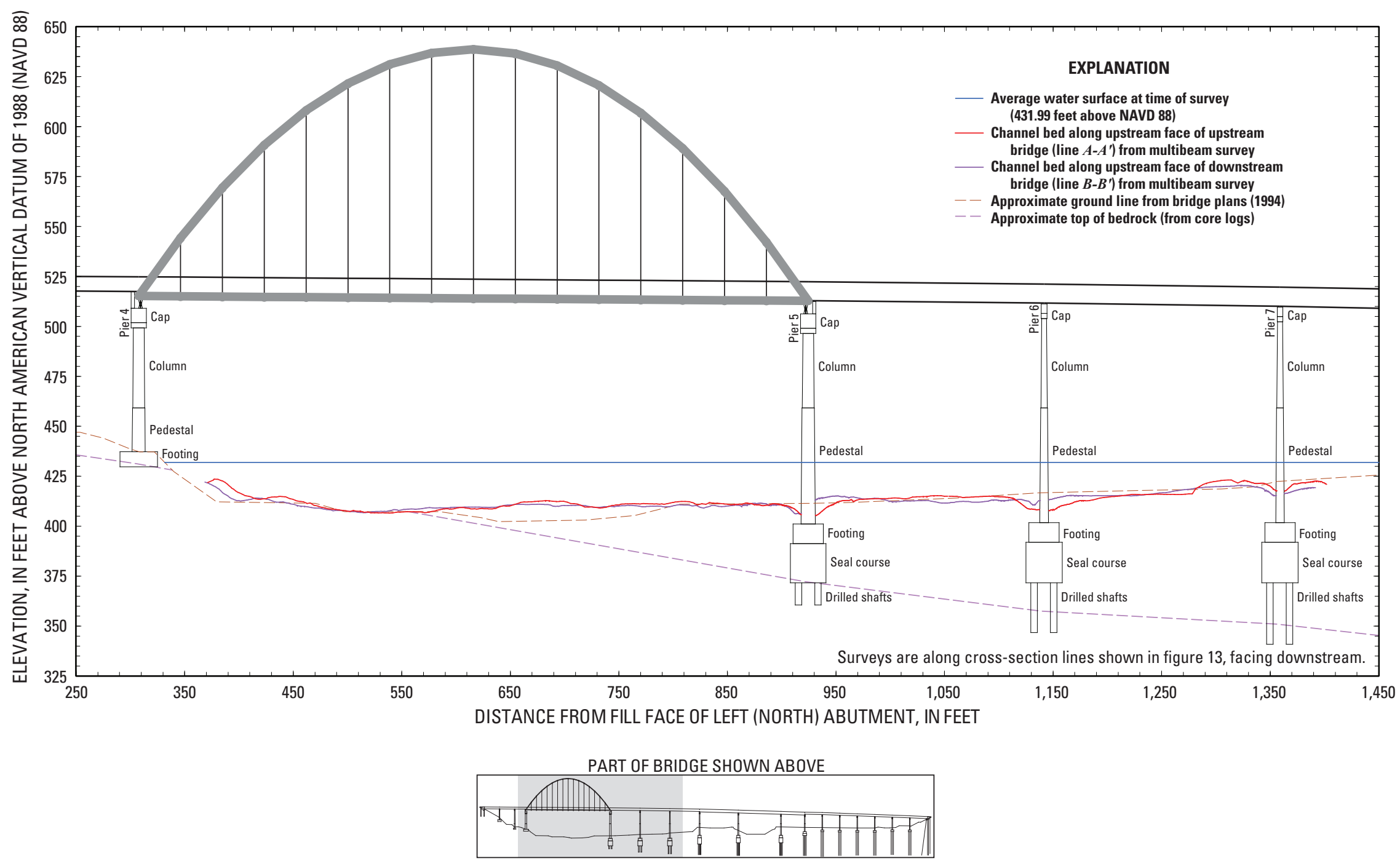

Figure 15. Key features, substructural and superstructural details, and surveyed channel bed along the upstream face of each bridge of dual bridge structure A5585 on State Highway 364 over the Missouri River near St. Louis, Missouri. 


\section{Structures A3292 and L0561 on Interstate 70}

Structures A3292 and L0561 are dual bridges on Interstate 70 on the northwestern side of the St. Louis metropolitan area, between Maryland Heights and St. Charles (figs. 1, 16). The survey was conducted on October 21, 2010, and the average water-surface elevation of the river in the survey area determined by the RTK GPS tide solution was $430.02 \mathrm{ft}$ (table 5). Flow on the Missouri River was about 91,600 ft $\mathrm{ft}^{3} \mathrm{~s}$ during the survey (table 5).

The survey area was about $3,280 \mathrm{ft}$ long and about $1,200 \mathrm{ft}$ wide, extending from the shallow area between spur dikes on the left to the right bank in the main channel (fig. 17). The upstream end of the survey area was about $1,370 \mathrm{ft}$ upstream from the centerline between structures A3292 and L0561 (figs. 16, 17). The channel-bed elevations ranged from about 403 to $420 \mathrm{ft}$ for most of the surveyed area (5 to 95 percentile range of the bathymetric data, fig. 17). A deep thalweg on the right (south) bank on the upstream end of the surveyed area was about $10 \mathrm{ft}$ deeper than the channel bed in the middle of the channel (fig. 17). The channel and thalweg deepened downstream from the bridges (fig. 17), likely because of the contraction of the channel caused by the building on the left bank downstream from the bridges. In the vicinity of the rock spur dike on the upstream left (north) side, deposits reached an elevation of about $424 \mathrm{ft}$ (fig. 17). Similar to the two upstream sites (structures A4017 and J1000, and dual bridge structure A5585), numerous medium and small dunes and ripples were detected throughout the channel, and larger dune features were detected in the channel thalweg downstream from the bridges (fig. 17). A localized deep scour hole at the end of what appears to be a shallow spur dike between the downstream bridge and the building on the left bank had a minimum elevation of about $397 \mathrm{ft}$ (fig. 17).

In the vicinity of the left main channel piers (pier 15 of upstream structure A3292 and pier 16 of downstream structure L0561; fig. 18), local scour was difficult to determine because a substantial debris raft at the nose of pier 15 of upstream structure A3292 made it impossible to acquire bathymetry data in the vicinity of the left main channel piers. A local scour hole caused by the debris raft had a minimum measured elevation of approximately $402 \mathrm{ft}$ near the upstream nose of pier 15 of upstream structure A3292 (figs. 18, 19), about $17 \mathrm{ft}$ below the average channel bed immediately upstream from the pile. The true minimum elevation of the scour hole was not measured, and likely is lower than the measured minimum of approximately $402 \mathrm{ft}$; however, based on the size and shape of the observable part of the scour hole, the true minimum elevation in the hole likely was well above the bottom of the seal course elevation of pier 15 of $378.00 \mathrm{ft}$ (fig. 19; table 6). Information from bridge plans indicates that pier 15 of upstream structure A3292 is founded on shafts drilled approximately $16 \mathrm{ft}$ in bedrock (table 6), with about $52 \mathrm{ft}$ of bed material between the bottom of the scour hole and bedrock near the upstream pier (fig. 19). Pier 16 of downstream structure L0561 is founded on a caisson on bedrock (fig. 20; table 6), and the bottom of the local scour hole near this pier is about $59 \mathrm{ft}$ above the bottom of the caisson and bedrock. It is likely that the shallow spur dike between the downstream bridge and the casino on the left bank limits the scour that can occur near the downstream pier.

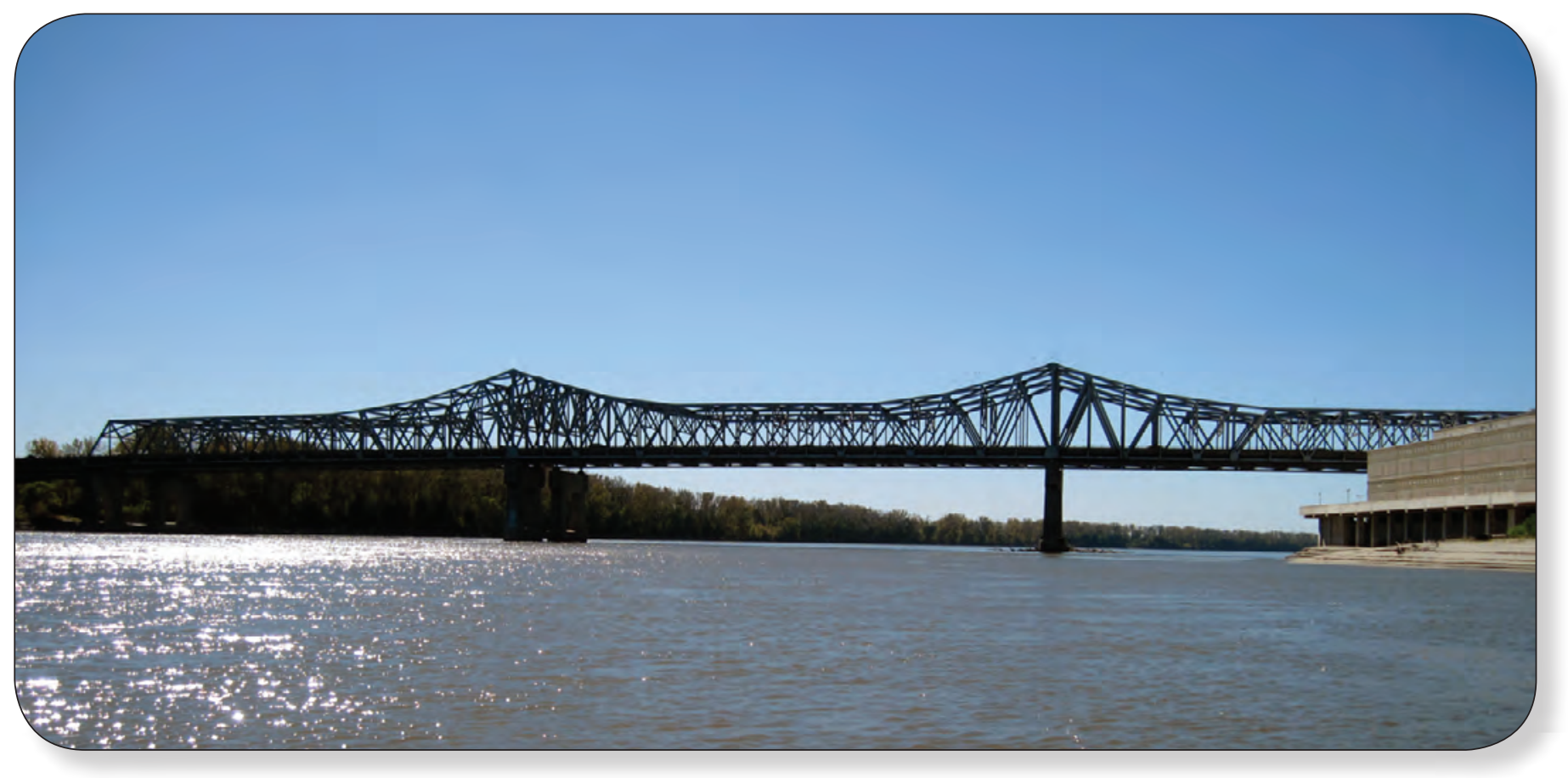




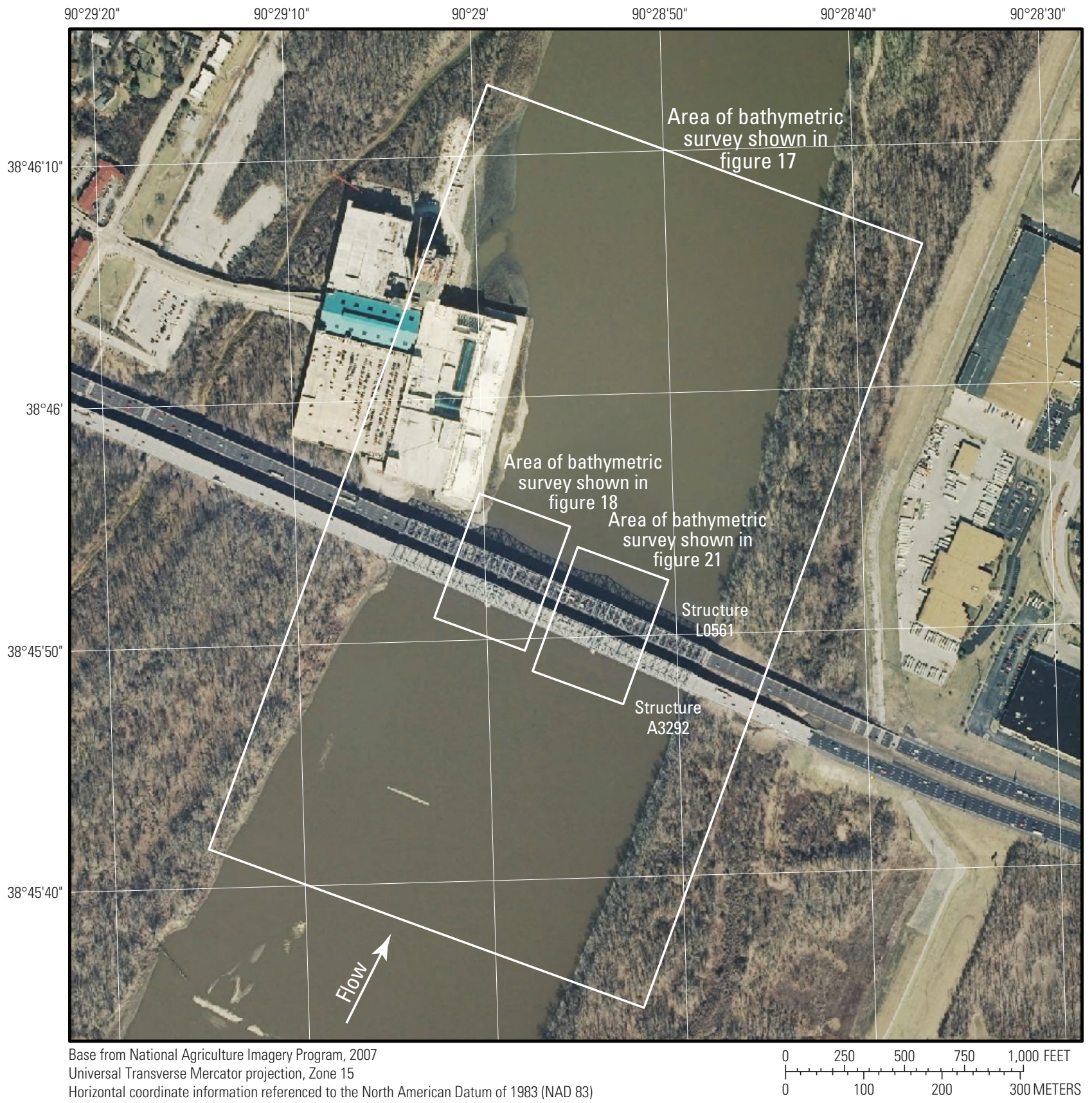

Figure 16. Location of the bathymetric survey area on the Missouri River near structures A3292 and L0561 on Interstate 70 near St. Louis, Missouri. 


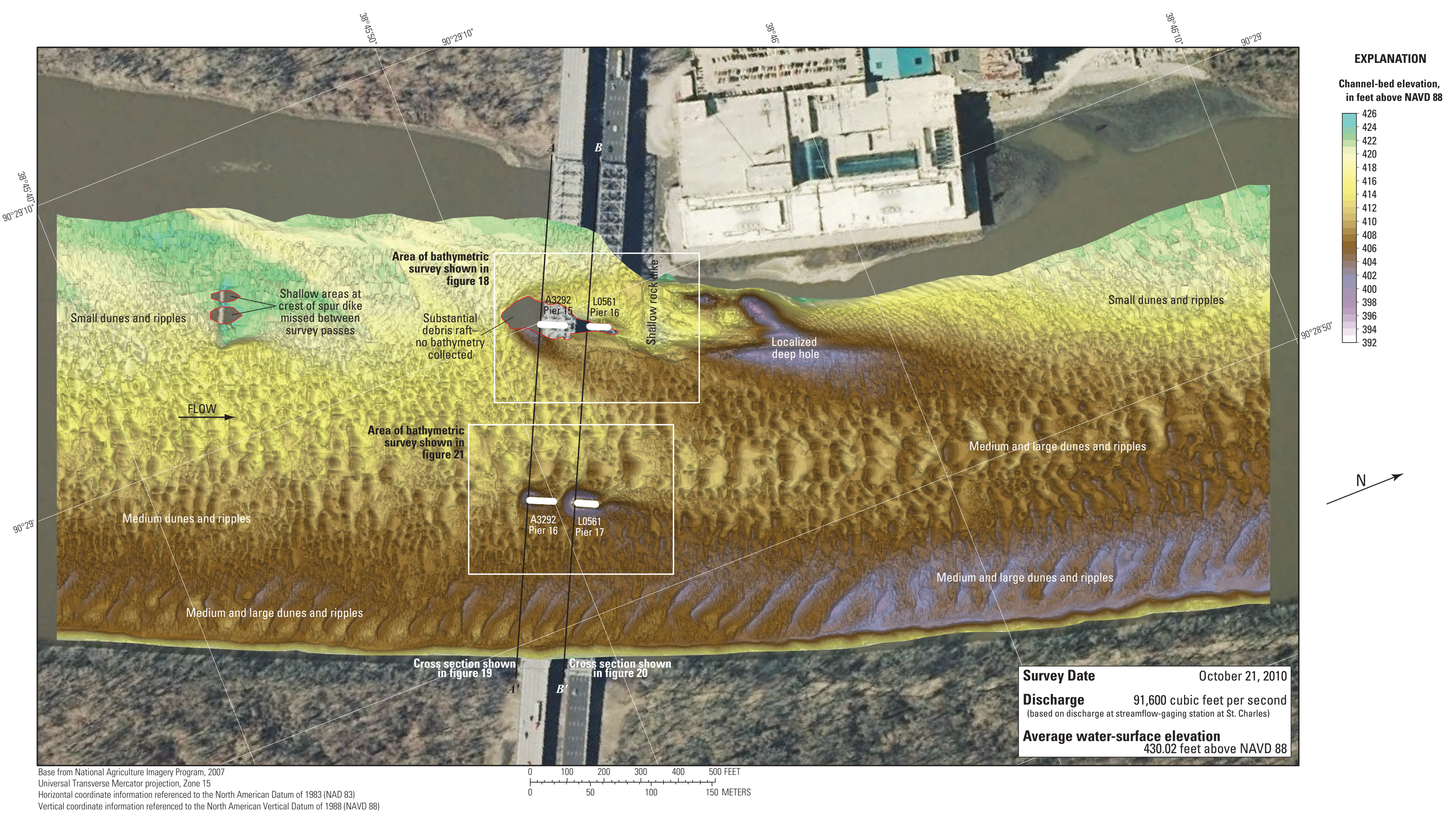

Figure 17. Bathymetric survey of the Missouri River channel in the vicinity of structures A3292 and L0561 on Interstate 70 near St. Louis, Missouri. 


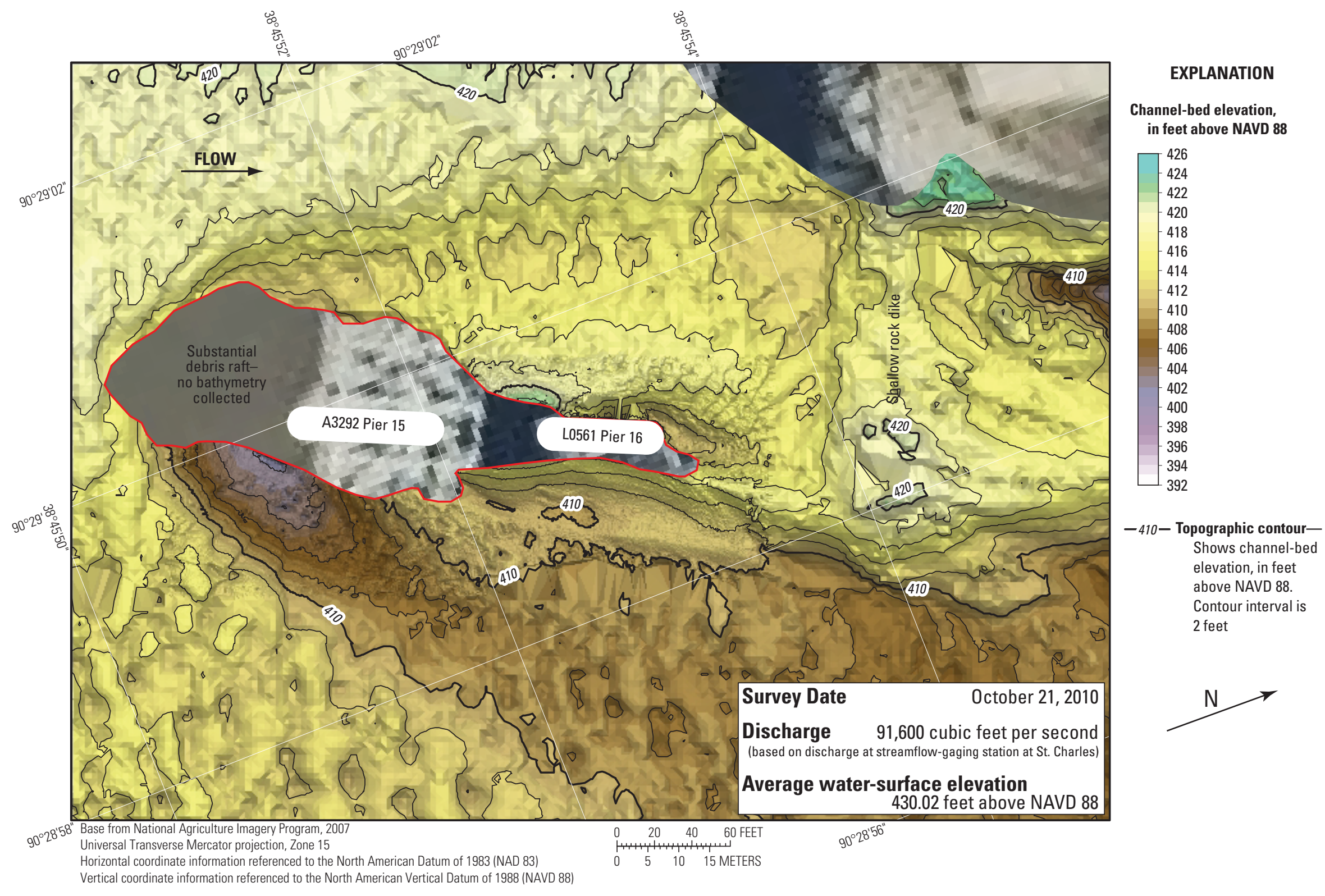

Figure 18. Bathymetric survey of the Missouri River channel in the vicinity of the left main channel piers of structures A3292 and L0561 on Interstate 70 near St. Louis, Missouri. 


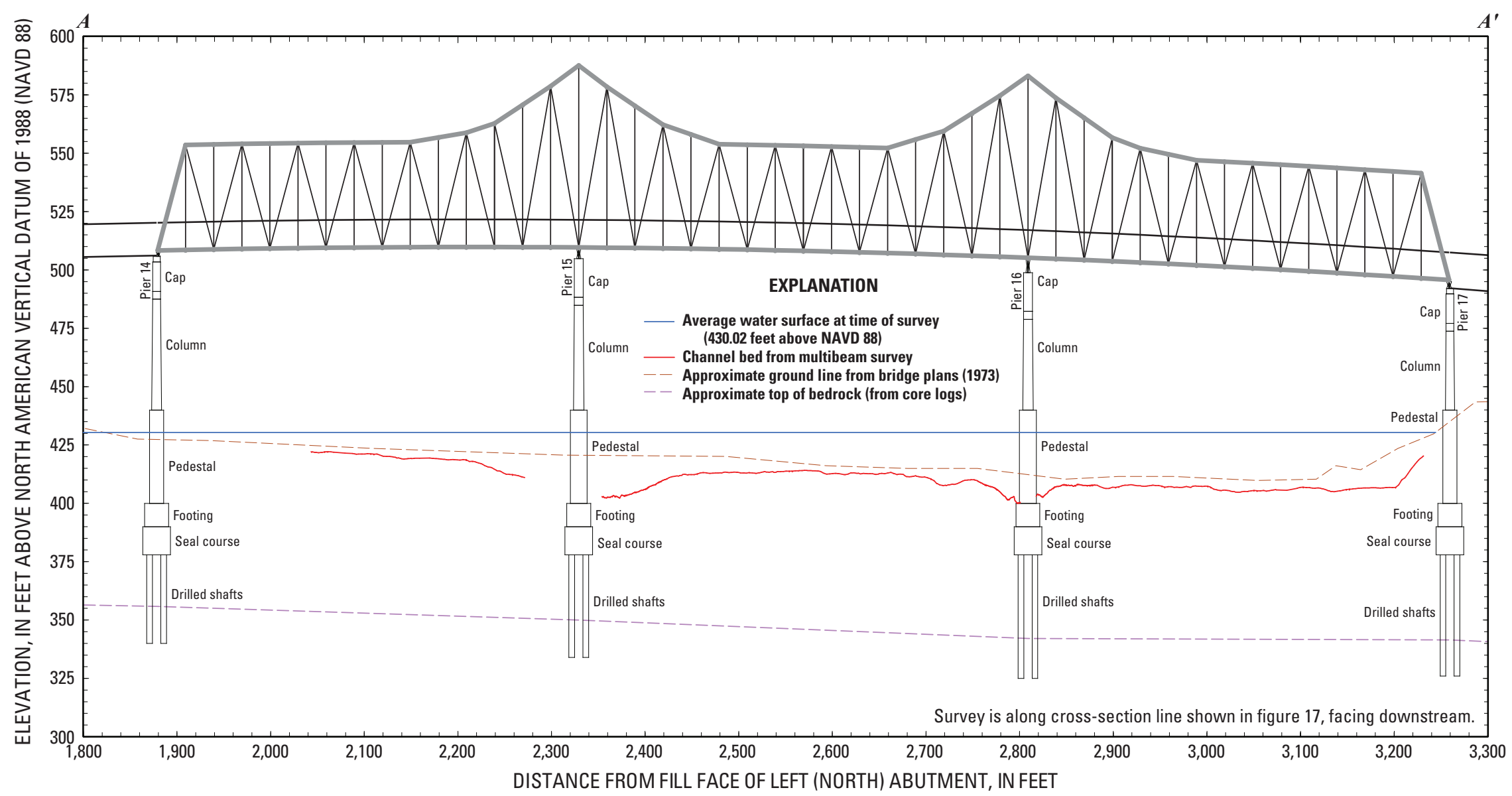

Figure 19. Key features, substructural and superstructural details, and surveyed channel bed of structure A3292 on Interstate 70 over the Missouri River near St. Louis,

Missouri.

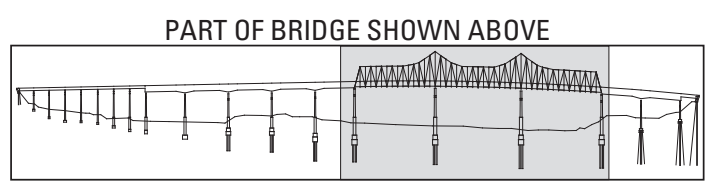



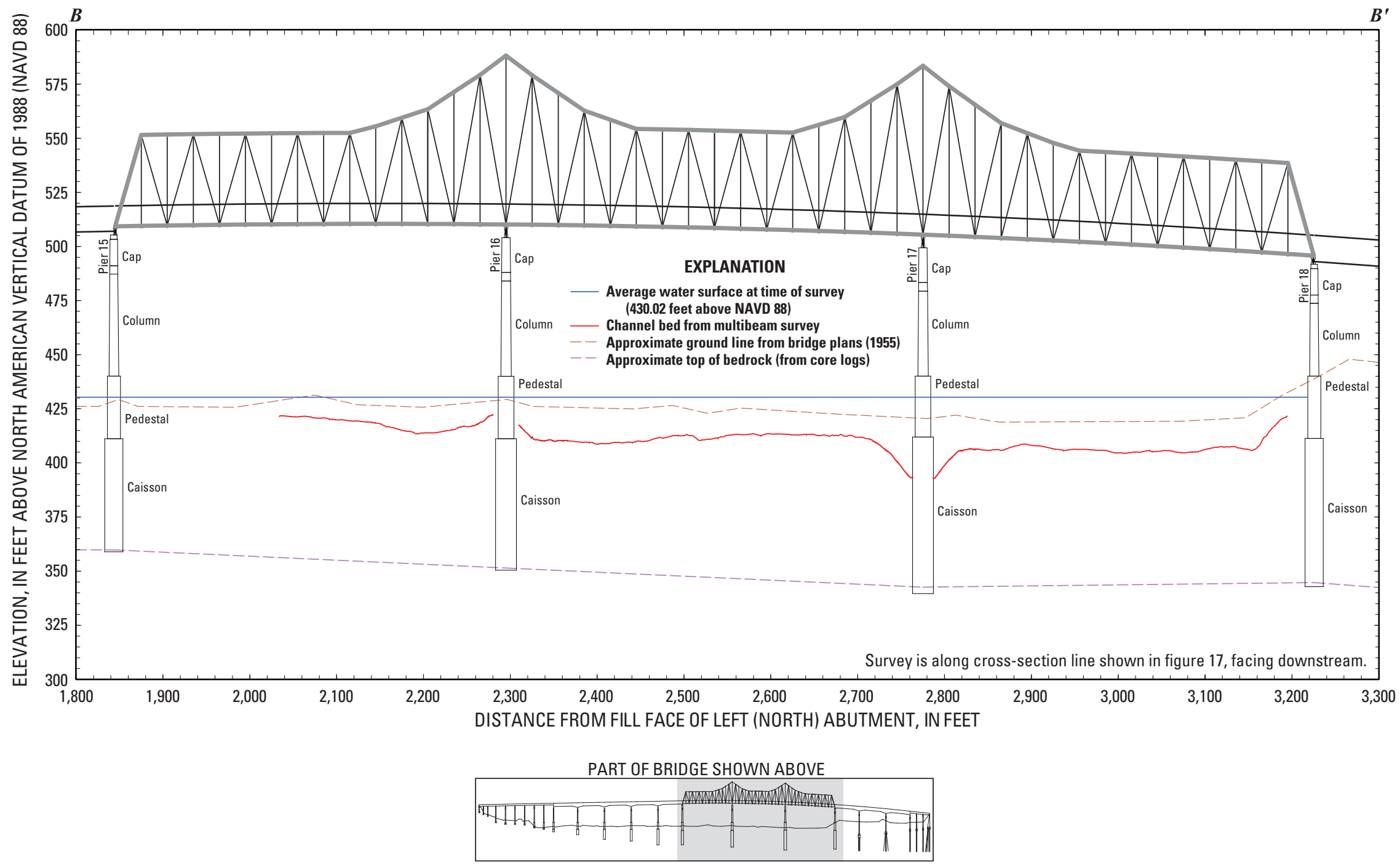

Figure 20. Key features, substructural and superstructural details, and surveyed channel bed of structure L0561 on Interstate 70 over the Missouri River near St. Louis , Missouri. 
Scour holes were present in the vicinity of the right main channel piers (fig. 21) of structures A3292 and L0561. The scour hole at upstream pier 16 had a minimum elevation of about $402 \mathrm{ft}$ (fig. 21; table 6), about $8 \mathrm{ft}$ below the average channel bed immediately upstream from the pier, whereas the scour hole at downstream pier 17 had a minimum elevation of about $393 \mathrm{ft}$ (fig. 21; table 6), about $15 \mathrm{ft}$ below the average channel bed immediately upstream from the pier. Information from bridge plans indicates that pier 16 of upstream structure A3292 is founded on shafts drilled $17 \mathrm{ft}$ into bedrock, with about $60 \mathrm{ft}$ of bed material between the bottom of the scour hole and bedrock (fig. 19; table 6). Pier 17 of structure L0561 is founded on a caisson on bedrock, with about $50 \mathrm{ft}$ of bed material between the bottom of the scour hole and bedrock (fig. 20; table 6).

An offset in the survey contours near pier 17 of downstream structure L0561 (fig. 21) indicates a mismatch of the horizontal position on adjacent survey lines. This discrepancy in horizontal position is a result of losing GPS signal where the survey lines passed under the bridge. Normally, all such mismatches in horizontal position are minimized or completely removed by post-processing the navigation data with POS-Pac ${ }^{\mathrm{TM}} \mathrm{MMS}^{\mathrm{TM}}$; however, the mismatch was not completely removed at this location. It was observed during a substantial part of the survey at this site, the satellite configuration was such that a navigation solution with a higher positional dilution of precision (PDOP) was established for the on-board GPS system, causing what is known as a "float" RTK solution rather than a "fixed" RTK solution. Whereas the positional accuracy of a "fixed" RTK solution is on the order of 0.03 to $0.07 \mathrm{ft}$, a "float" RTK solution typically has a positional accuracy of 0.3 to $0.7 \mathrm{ft}$; when under the bridge, the positional accuracy has been observed to drift as high as 3 to $7 \mathrm{ft}$. The "float" RTK solution obtained for a substantial part of the survey at this site resulted in a lower overall accuracy of the horizontal position of the boat when GPS signal was re-acquired away from the bridges, even after post-processing the navigation data and combining the GPS and IMU raw data in an SBET file. The SBET file helped minimize the effects of drift in positional accuracy when under the bridges, but it did not completely remove the 0.3 to $0.7 \mathrm{ft}$ horizontal positional accuracy when away from the bridge while in a "float" RTK solution mode.

Vertical positional accuracy is related to horizontal positional accuracy, so the vertical position of the boat also was compromised when not in a "fixed" or "float" RTK solution mode. The error in the vertical positional accuracy during periods of GPS outage under the bridge was, however, minimized by linearly interpolating the vertical position of the boat from one "fixed" or "float" RTK solution position to the next one available on the survey line. In this way, the vertical positional accuracy was maintained at less than $0.5 \mathrm{ft}$ for most of the survey (see discussion in Error Estimation section earlier in this report).

The surveyed bed throughout the channel is approximately $5 \mathrm{ft}$ lower than the original ground line from bridge plans at the time of construction (1973) at upstream structure A3292 (fig. 19). The surveyed bed is approximately $15 \mathrm{ft}$ lower than the original ground line from bridge plans at construction (1955) at downstream structure L0561 throughout the channel (fig. 20). These changes in bed elevation indicate a decrease in the overall bed elevation at this site with time, likely caused in part by the constriction near the building on the left bank. 


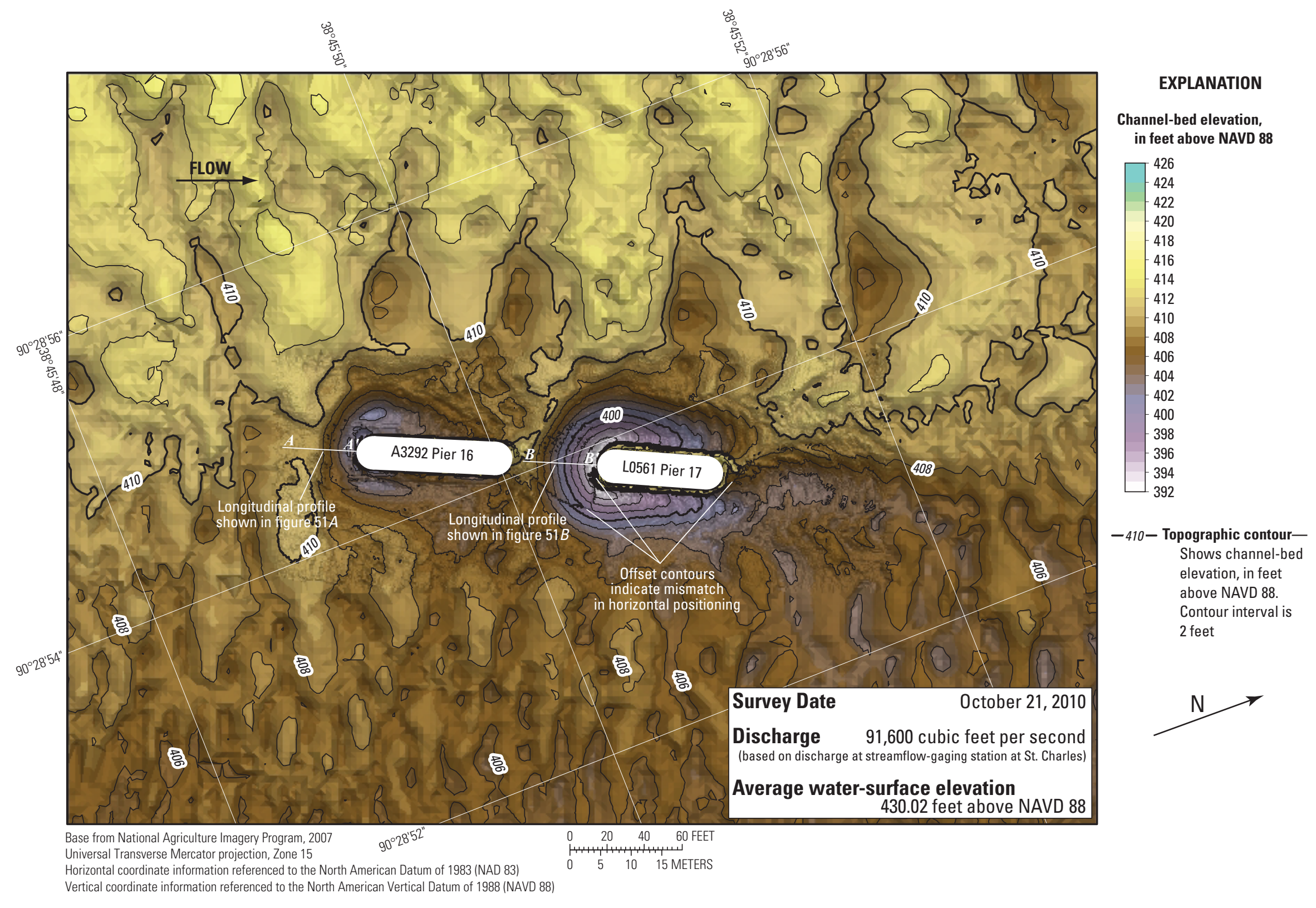

Figure 21. Bathymetric survey of the Missouri River channel in the vicinity of the right main channel piers of structures A3292 and L0561 on Interstate 70 near St. Louis, Missouri. 


\section{Dual Bridge Structure A4557 on State Highway 370}

Structure A4557 consists of twin bridges on State Highway 370 on the northwestern side of the St. Louis metropolitan area, between Bridgeton and St. Charles (figs. 1, 22). The survey was conducted on October 22, 2010; the average water-surface elevation of the river in the survey area determined by the RTK GPS tide solution was $428.41 \mathrm{ft}$ (table 5). Flow on the Missouri River was about $90,000 \mathrm{ft}^{3} / \mathrm{s}$ during the survey (table 5).

The survey area was about 3,280 ft long and averaged about 1,100 ft wide, extending from rock dikes and the channel bank on the left to shallow areas on the right in the main channel (fig. 23). The upstream end of the survey area was about 1,480 ft upstream from the centerline of structure A4557 (figs. 22, 23). The channel-bed elevations ranged from about 402 to $413 \mathrm{ft}$ for most of the surveyed area ( 5 to 95 percentile range of the bathymetric data), except for a localized deep area along the toe of a rock outcrop along the left side of the channel, which had a minimum elevation of approximately $395 \mathrm{ft}$ (fig. 23; table 5). The rock outcrop appears to extend from a point upstream from the bridge to the rock dikes downstream from the bridge (fig. 23).

Small scour holes were present in the vicinity of the main channel piers, except those near the spur dike on the right side of the channel (pier $4 \mathrm{C}$ at both bridges; fig. 24). The scour hole at upstream (eastbound) pier $2 \mathrm{C}$ had a minimum elevation of about $403 \mathrm{ft}$ (fig. 24; table 6), about $4 \mathrm{ft}$ below the average channel bed immediately upstream from the pier, and the scour hole at downstream (westbound) pier $2 \mathrm{C}$ had a minimum elevation of about $401 \mathrm{ft}$ (fig. 24; table 6), about 6 $\mathrm{ft}$ below the average channel bed immediately upstream from the pier. However, the scour hole at upstream pier $3 \mathrm{C}$ had a minimum elevation of about $400 \mathrm{ft}$ (fig. 24; table 6), about 7 $\mathrm{ft}$ below the average channel bed immediately upstream from the pier, whereas the scour hole at downstream pier $3 \mathrm{C}$ had a minimum elevation of about $402 \mathrm{ft}$ (fig. 24; table 6), about $4 \mathrm{ft}$ below the average channel bed immediately upstream from the pier. There essentially was no scour hole around either upstream or downstream pier 4C (fig. 24); however, the spur dike adjacent to these piers caused a local deep hole that reached a minimum elevation of about $403 \mathrm{ft}$ (fig. 23; table 6). These piers essentially are embedded in the rock of the dike, which will limit or prevent additional scour near both of them. Material from the toe of the spur dike extends to downstream pier 3C, and may limit scour near that pier as well; however, a point cloud visualization of the multibeam depth points obtained during the survey clearly shows the exposed footing of upstream pier 3C (fig. 25).

A substantial scour hole was observed at the railroad bridge pier upstream from pier 2C (fig. 24). The hole had a minimum elevation of $393 \mathrm{ft}$ at the nose of the pier, about $17 \mathrm{ft}$ below the average channel bed immediately upstream from the pier (fig. 24). A smaller scour hole also was present at the railroad bridge pier upstream from pier 4C, which had a minimum elevation of $402 \mathrm{ft}$ at the nose of the pier, about $5 \mathrm{ft}$ below the average channel bed immediately upstream from the pier (fig. 24). The scour holes at the railroad bridge piers did not appear to affect the scour at piers $2 \mathrm{C}$ or $4 \mathrm{C}$ of structure A4557 (fig. 24).

As with upstream structure A5585, information from bridge plans indicates that both bridges of structure A4557 are exactly the same in cross section for the part of the bridges across the main channel, which permits the cross-section data for each bridge to be examined together (fig. 26). The main channel piers of both bridges of structure A4557 are founded on shafts drilled $15 \mathrm{ft}$ into bedrock (fig. 26; table 6). Depth of bed material between bedrock and the bottom of the various scour holes at dual bridge structure A4557 ranges from 43 to $67 \mathrm{ft}$ because of the sloping bedrock and channel bed in the area (fig. 26; table 6). The minimum elevation in each of the scour holes is more than $9 \mathrm{ft}$ higher than the bottom of the seal course elevation at each pier (fig. 26; table 6). The surveyed bed appears to be about $8 \mathrm{ft}$ lower than the original ground line from bridge plans at the time of construction in 1994 (fig. 26). Although the footing of upstream pier 3C is exposed (figs. 24, $25)$, the exposure is minimal compared to the overall substructure that remains buried (fig. 26).

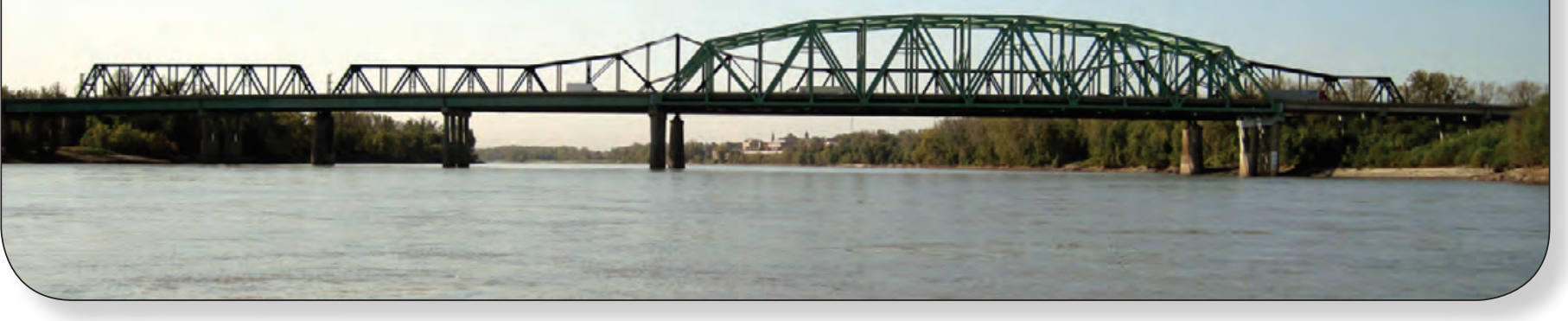

Dual bridge structure A4557 on State Highway 370. The Wabash railroad bridge is in the background. 


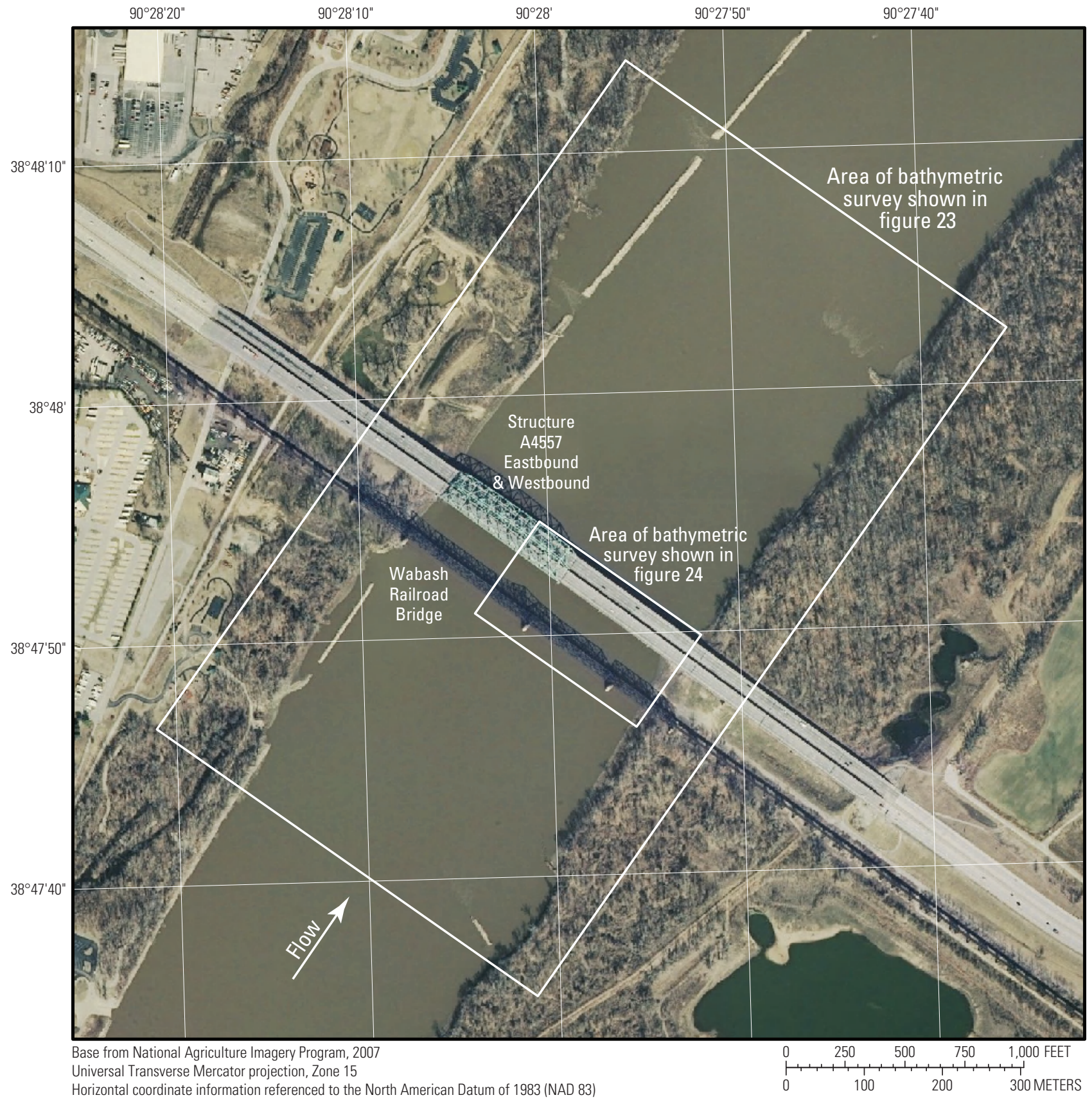

Figure 22. Location of the bathymetric survey area on the Missouri River near dual bridge structure A4557 on State Highway 370 near St. Louis, Missouri. 


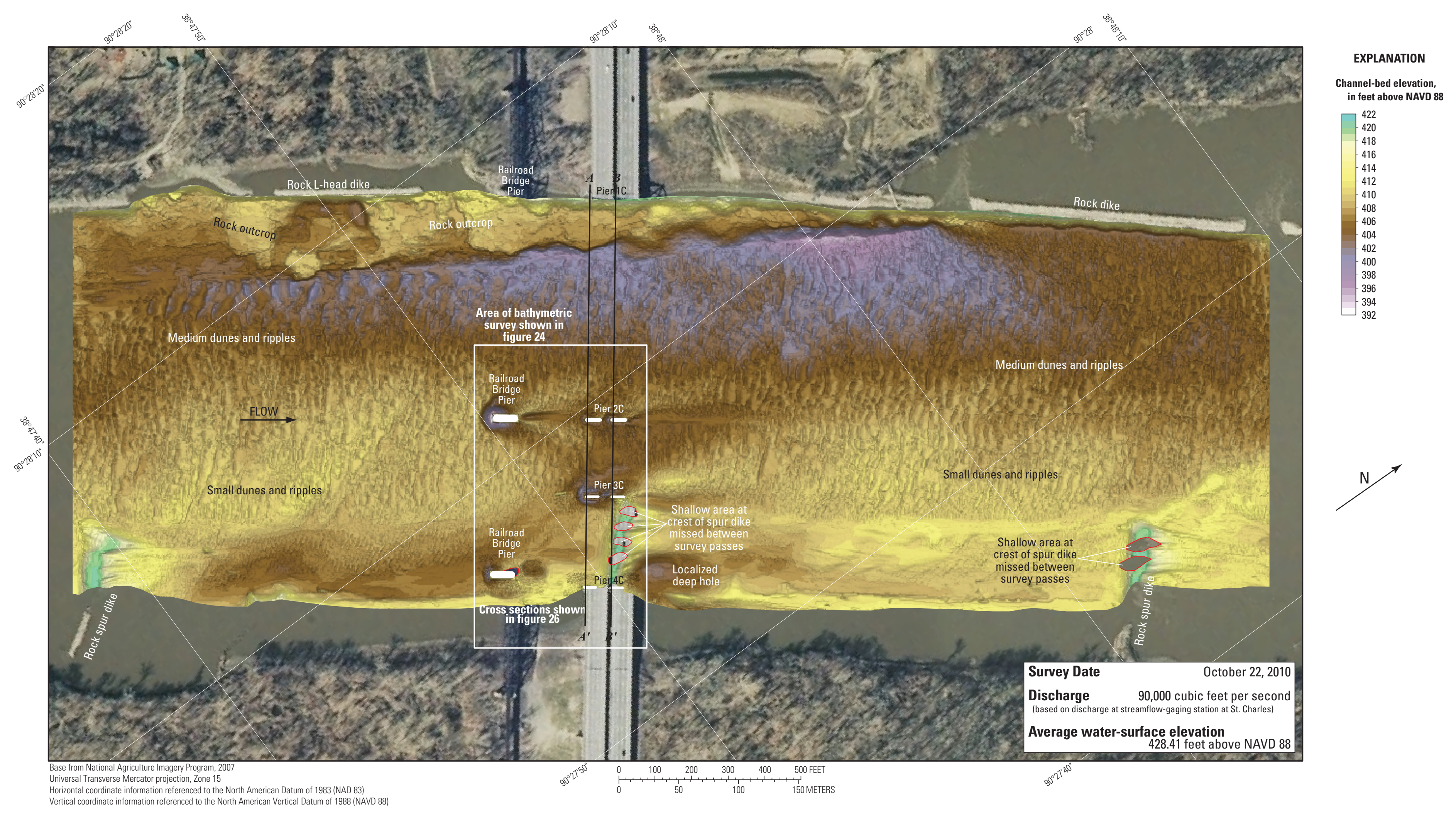

Figure 23. Bathymetric survey of the Missouri River channel in the vicinity of dual bridge structure A4557 on State Highway 370 near St. Louis, Missouri. 


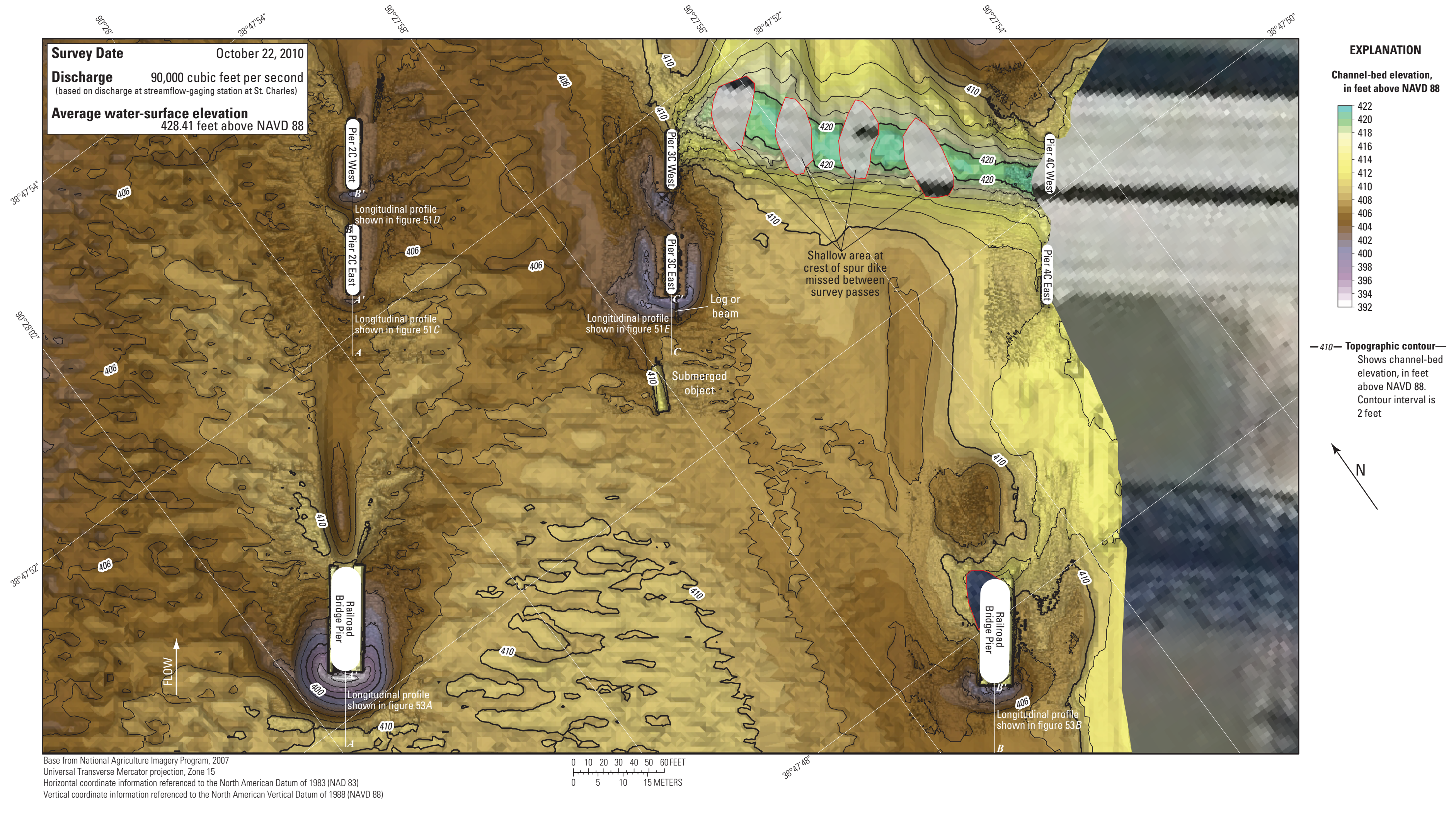

Figure 24. Bathymetric survey of the Missouri River channel in the vicinity of the main channel piers of dual bridge structure A4557 on State Highway 370 near St. Louis, Missouri. 


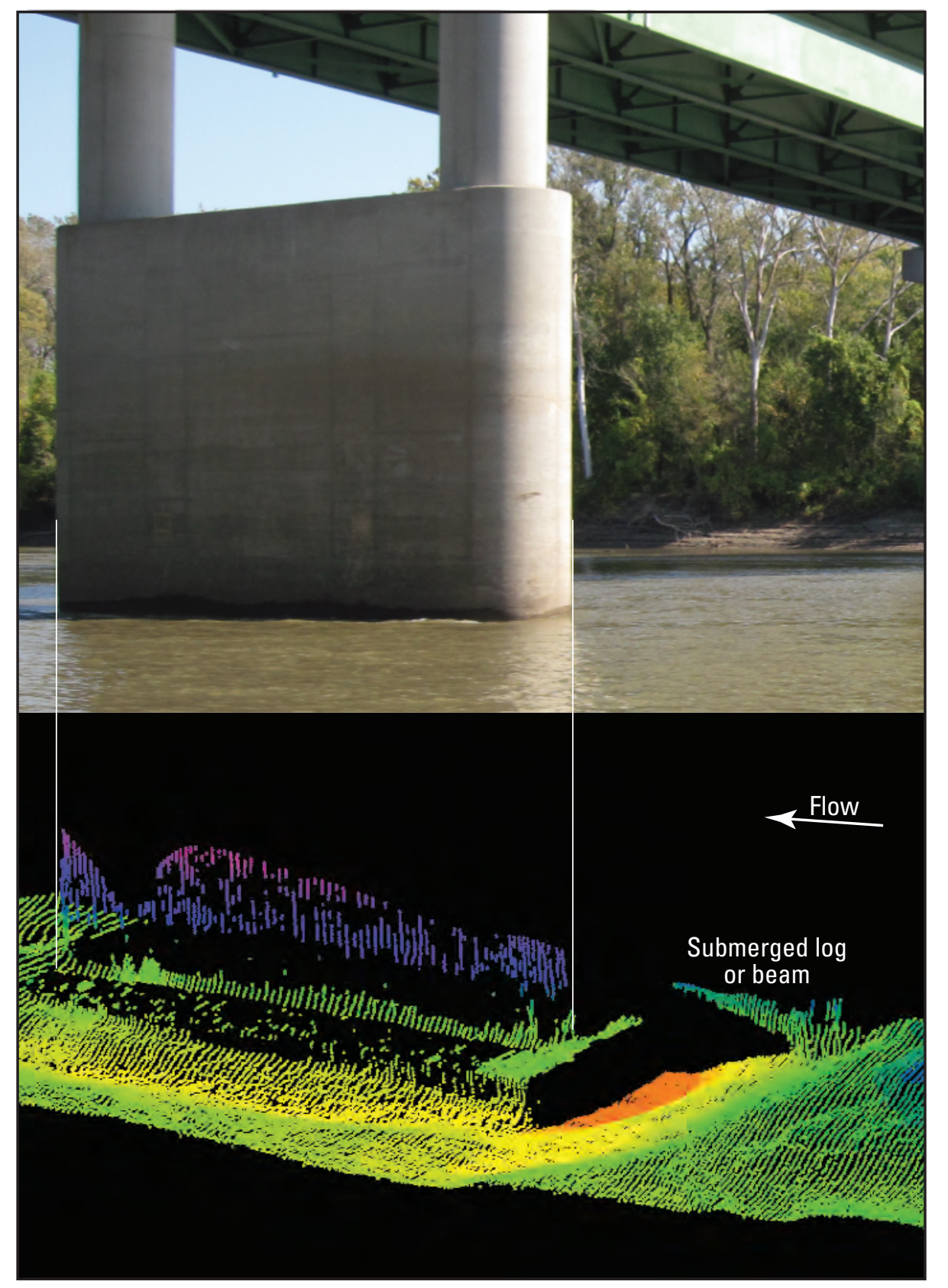

\section{EXPLANATION}

Elevation of point, in feet above the North American Vertical Datum of 1988

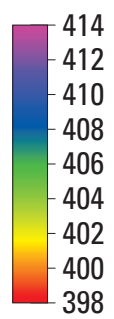

Figure 25. Point cloud visualization of the channel bed and left (west) side of upstream pier 3C of dual bridge structure A4557 on State Highway 370 over the Missouri River near St. Louis, Missouri. 


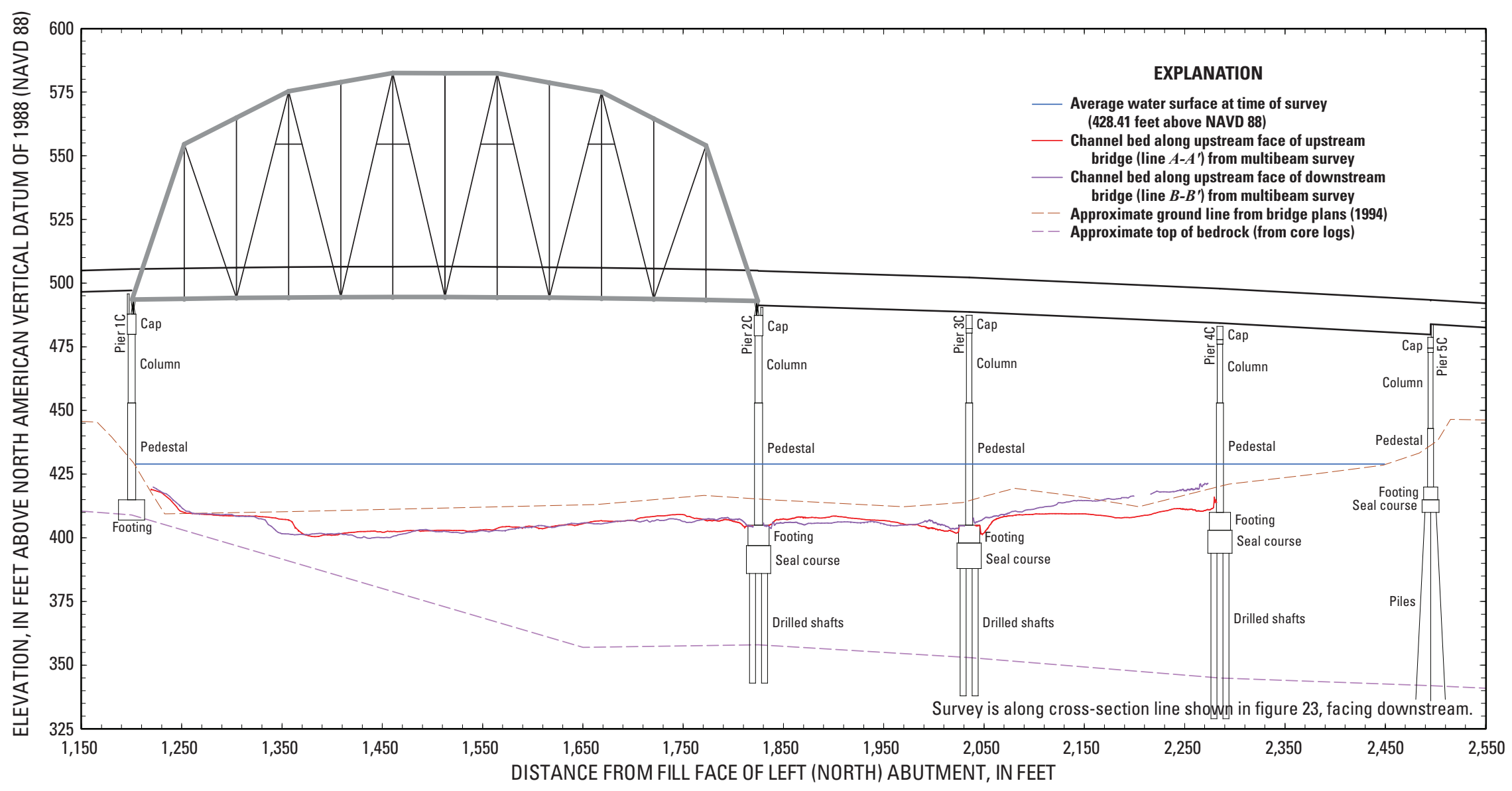

PART OF BRIDGE SHOWN ABOVE

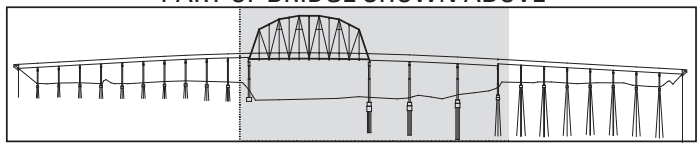

Figure 26. Key features, substructural and superstructural details, and surveyed channel bed along the upstream face of each bridge of dual bridge structure A4557 on State Highway 370 over the Missouri River near St. Louis, Missouri. 


\section{Structure A3047 on U.S. Highway 67}

Structure A3047 is a single bridge on U.S. Highway 67 on the northern side of the St. Louis metropolitan area, between Florissant and West Alton (figs. 1, 27). The survey was conducted on October 25, 2010; the average watersurface elevation of the river in the survey area determined by the RTK GPS tide solution was $410.19 \mathrm{ft}$ (table 5). Flow on the Missouri River was about $87,400 \mathrm{ft}^{3} / \mathrm{s}$ during the survey (table 5).

The survey area was about 3,280 ft long and about 985 $\mathrm{ft}$ wide, extending from the L-head dikes on the left to the shallow area between spur dikes on the right in the main channel (fig. 28). The upstream end of the survey area was about $1,540 \mathrm{ft}$ upstream from the centerline of structure A3047 (figs. 27, 28). The channel-bed elevations ranged from about 383 to $399 \mathrm{ft}$ for most of the surveyed area (5 to 95 percentile range of the bathymetric data, fig. 28). A deep thalweg on the left (north) bank was about $15 \mathrm{ft}$ deeper than the channel bed in the middle of the channel (fig. 28). In the vicinity of the rock spur dike on the right (south) side near the bridge, deposits reached an elevation of about $403 \mathrm{ft}$ (fig. 28). Numerous medium and small dunes and ripples were detected throughout the channel, and larger dune features with superimposed small dunes and ripples were detected throughout the upstream channel and in the downstream channel thalweg (fig. 28).

In the immediate vicinity of the left main channel pier (pier 10, fig. 29), the channel thalweg had a minimum elevation of about $383 \mathrm{ft}$ (table 6), which is about $36 \mathrm{ft}$ above the bottom of the seal course elevation of $346.50 \mathrm{ft}$ (fig. 30; table 6). Pier 10 is essentially embedded in the rock of an L-head dike, which will limit or prevent scour at this pier (fig. 30). Information from bridge plans indicates that pier 10 is founded on shafts drilled $13 \mathrm{ft}$ into bedrock, with about $80 \mathrm{ft}$ of bed material between the channel thalweg and bedrock at the bridge, and about $89 \mathrm{ft}$ of bed material between the bed at the nose of the pier and bedrock (fig. 30; table 6). The scour hole in the vicinity of the upstream railroad bridge pier was essentially indistinguishable from the channel thalweg (fig. 29). The remnant of an old bridge pier was present in the channel downstream from the existing railroad bridge pier (fig. 29).

A scour hole was present in the vicinity of the central main channel pier (pier 11, fig. 31), with a minimum elevation of about $380 \mathrm{ft}$, about $11 \mathrm{ft}$ below the average channel bed immediately upstream from the pier (fig. 31; table 6). Information from bridge plans indicates that pier 11 is founded on shafts drilled $15 \mathrm{ft}$ into bedrock, with about $66 \mathrm{ft}$ of bed material between the bottom of the scour hole and bedrock (fig. 30; table 6). A substantial scour hole also was present in the vicinity of the railroad bridge pier upstream from pier 11, but it did not appear to have an effect on pier 11 (fig. 31). The remnant of another old bridge pier was present downstream from the existing railroad bridge pier (fig. 31). An offset in the contours near the railroad bridge pier indicates a minor mismatch of the horizontal positioning on adjacent survey lines near the railroad bridge. The cause for this mismatch is the same as that described for a similar offset observed at structures A3292 and L0561 on Interstate 70.

A small scour hole was present in the vicinity of the right main channel pier (pier 12, fig. 32), with a minimum elevation of about $392 \mathrm{ft}$, about $5 \mathrm{ft}$ below the average channel bed immediately upstream from the pier (fig. 32; table 6). Information from bridge plans indicates that pier 12 is founded on shafts drilled $26 \mathrm{ft}$ into bedrock, with about $56 \mathrm{ft}$ of bed material between the bottom of the scour hole and bedrock (fig. 30; table 6). As with pier 11, a scour hole also was present in the vicinity of the railroad bridge pier upstream from pier 12, but it did not appear to have an effect on pier 12 (fig. 32). Once again, the remnant of another old bridge pier was present downstream from the existing railroad bridge pier, resulting in a shallow area where no bathymetry was collected (fig. 32).

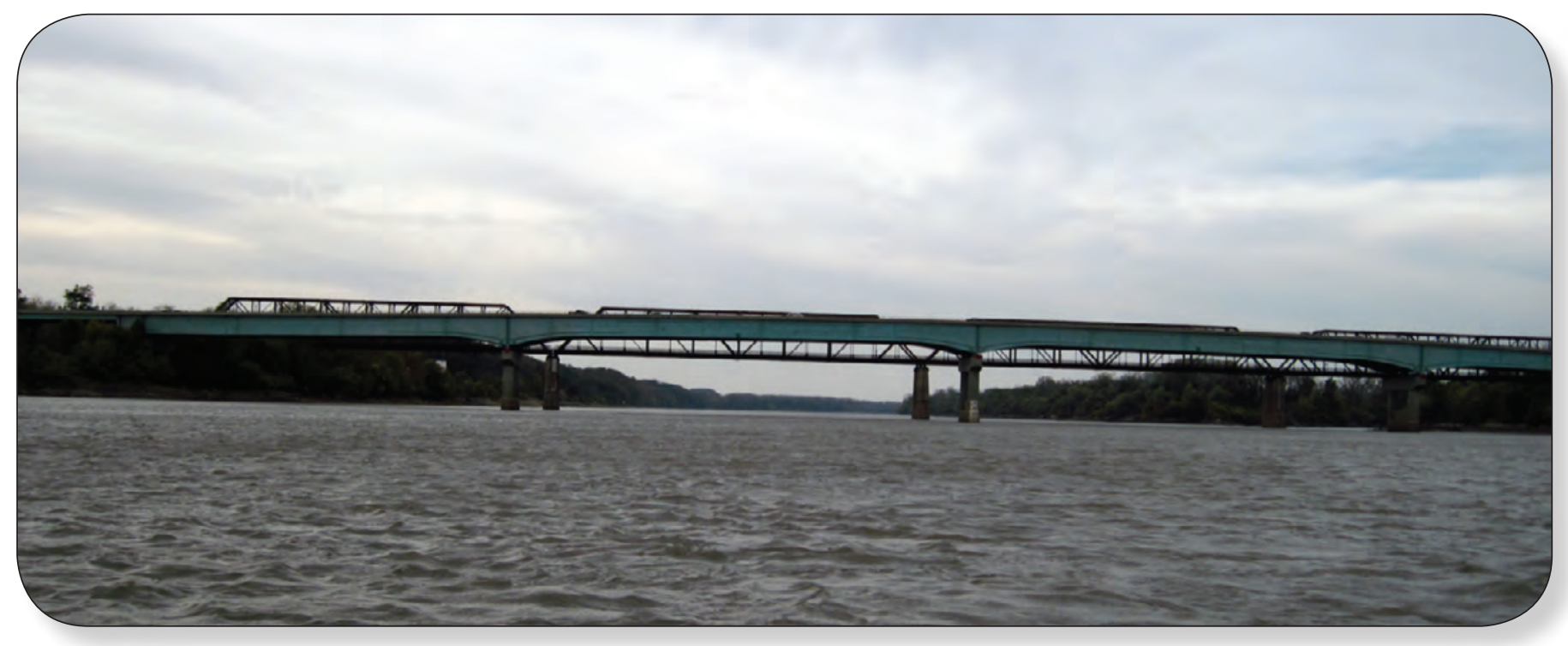

Structure A3047 on U.S. Highway 67. The Bellefontaine railroad bridge is in the background. 


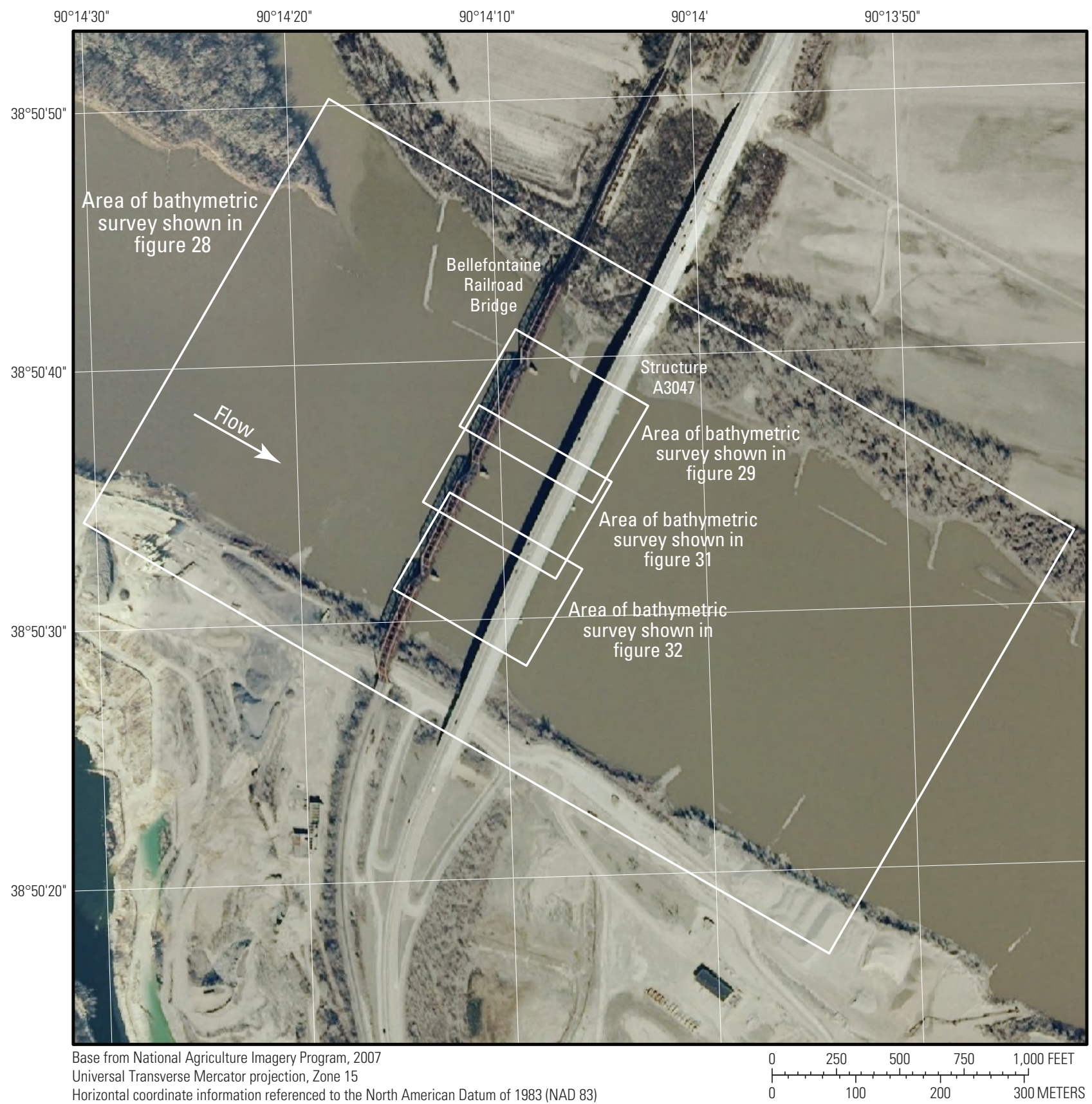

Figure 27. Location of the bathymetric survey area on the Missouri River near structure A3047 on U.S. Highway 67 near St. Louis, Missouri.

A Level II scour assessment was performed at this site in November 2002 (Huizinga and Rydlund, 2004), and the surveyed channel bed from the multibeam scan was similar to the channel bed from the Level II scour survey for most of the channel except the scour holes near the piers and the deep thalweg near the left (north) bank (fig. 30). Furthermore, the multibeam survey and the Level II survey are within $5 \mathrm{ft}$ of the approximate ground line from bridge plans when the bridge was built in 1974, except near the left bank. The similarity of the bed elevations through time imply there has been little to no long-term net degradation or aggradation at this site. The multibeam survey captures both the thalweg and the correct location of the L-head dike (figs. 28, 30), whereas the Level II survey appears to have a gap in stationing between the bathymetry point near pier 10 and the next point in the channel, essentially not capturing the thalweg. The L-head dike on the left bank is indicated as part of the 1974 ground line from bridge plans, but the plans indicate that the dike protrudes further into the channel. 


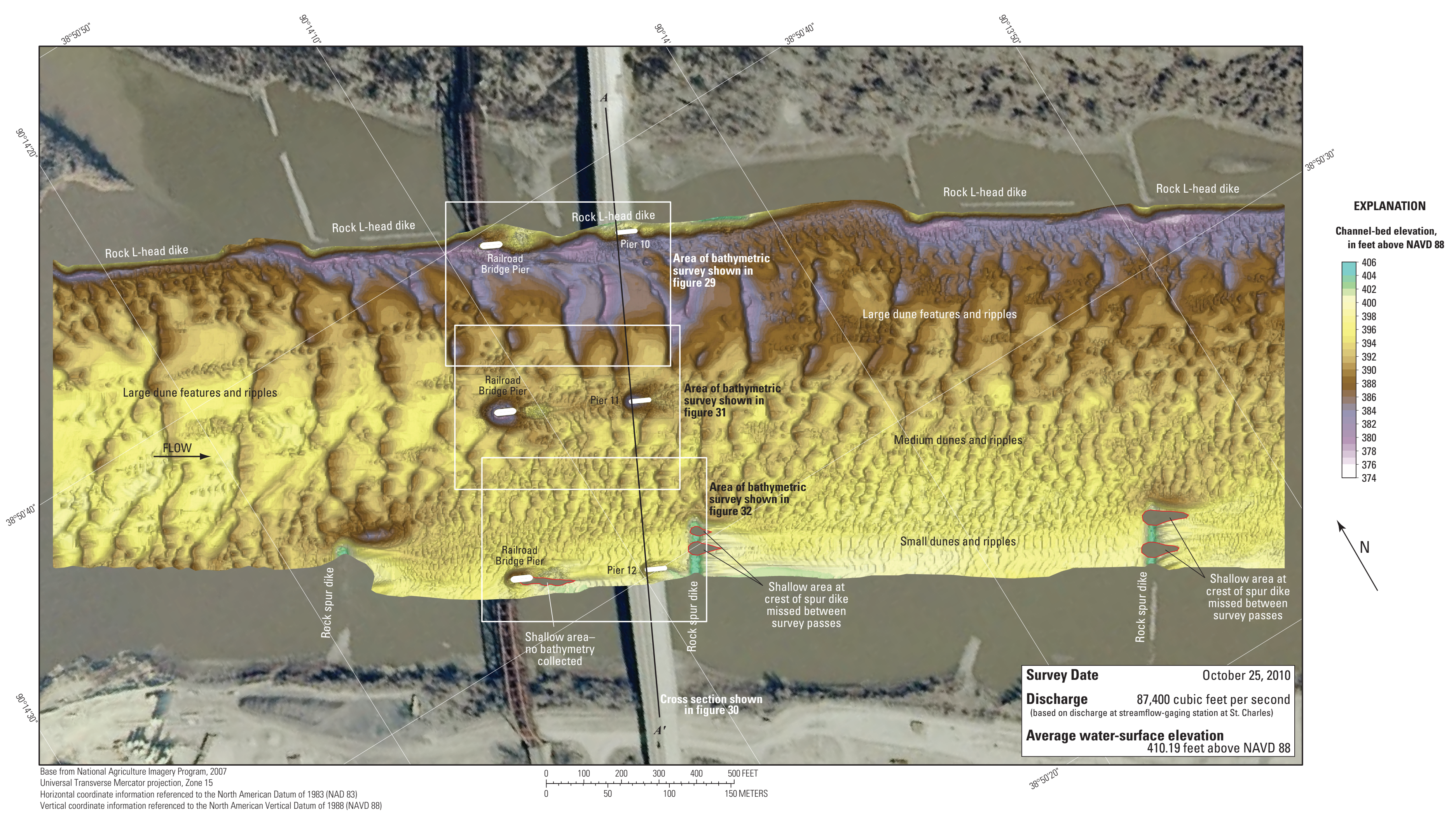

Figure 28. Bathymetric survey of the Missouri River channel in the vicinity of structure A3047 on U.S. Highway 67 near St. Louis, Missouri. 


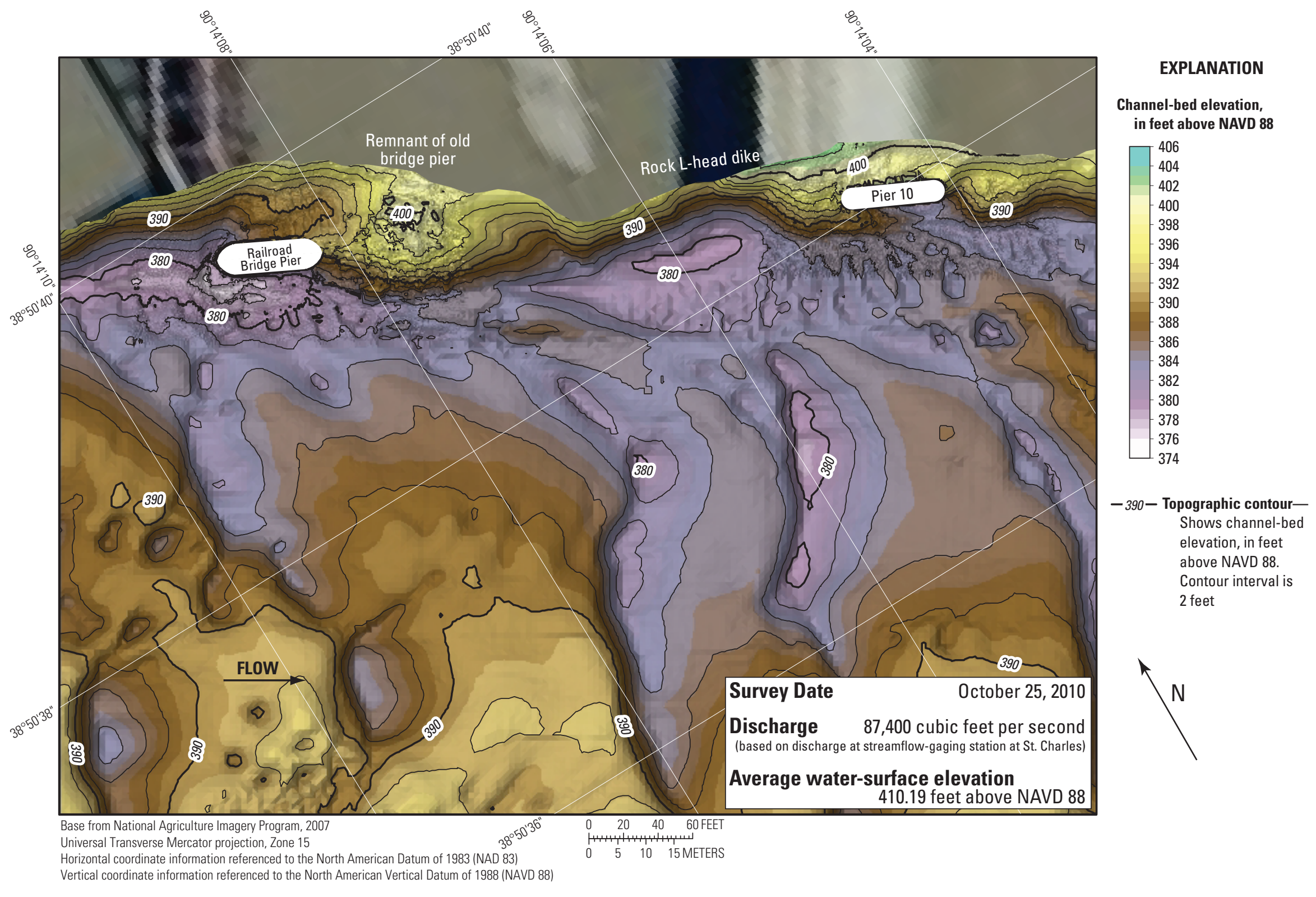

Figure 29. Bathymetric survey of the Missouri River channel in the vicinity of the left main channel pier of structure A3047 on U.S. Highway 67 near St. Louis, Missouri. 


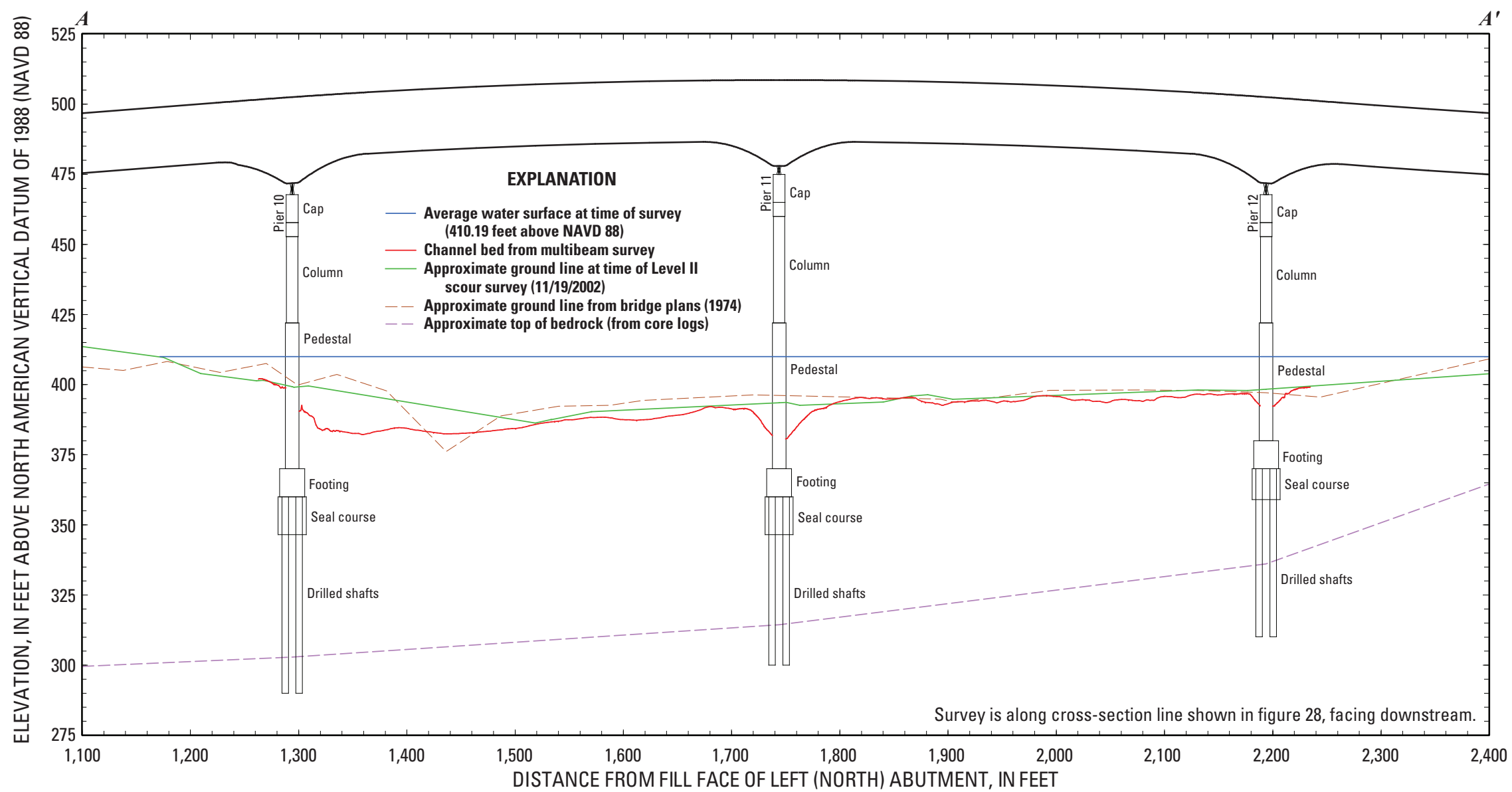

Figure 30. Key features, substructural and superstructural details, and surveyed channel bed of structure A3047 on U.S. Highway 67 over the Missouri River near St. Louis, Missouri. 


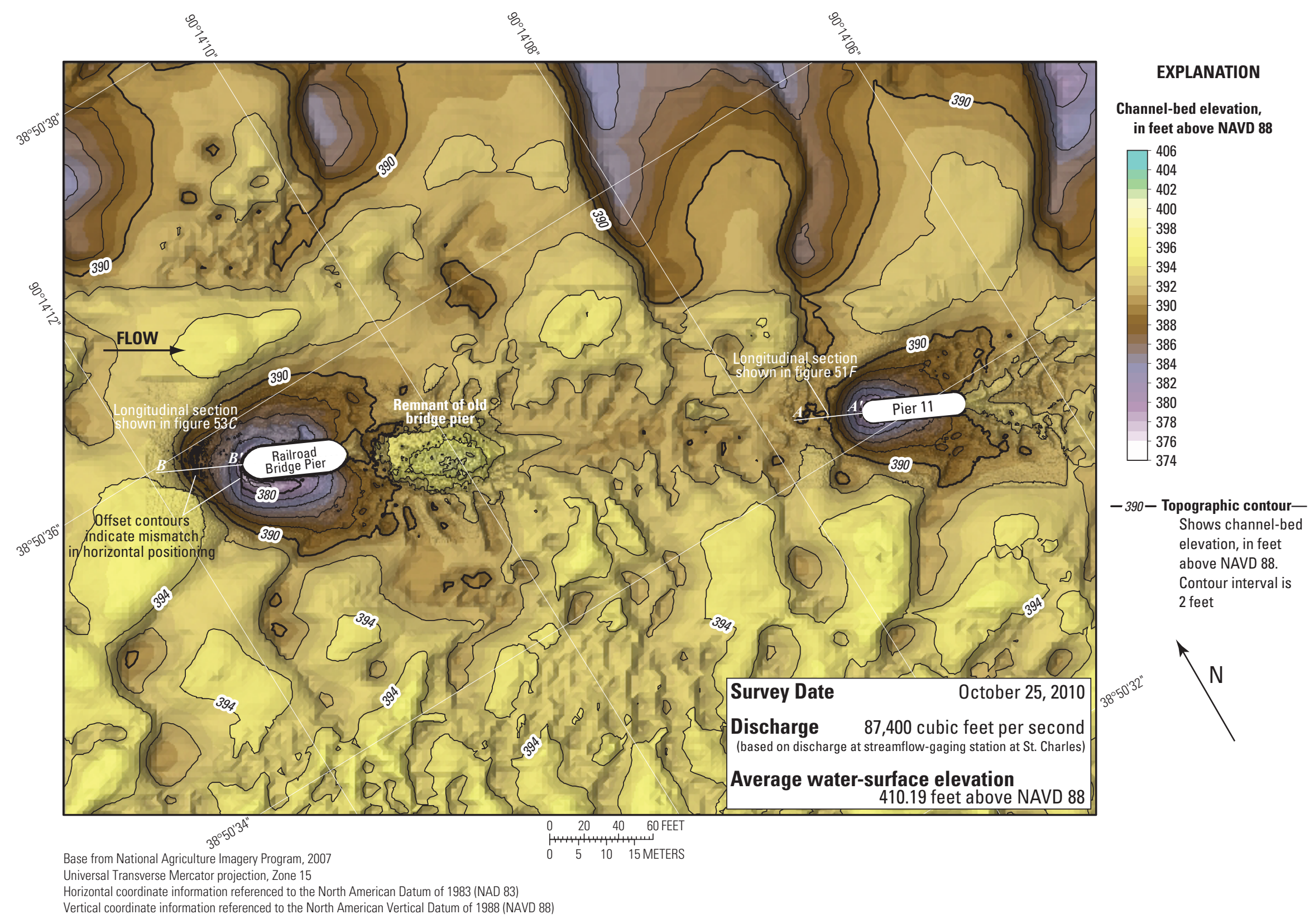

Figure 31. Bathymetric survey of the Missouri River channel in the vicinity of the central main channel pier of structure A3047 on U.S. Highway 67 near St. Louis, Missouri. 


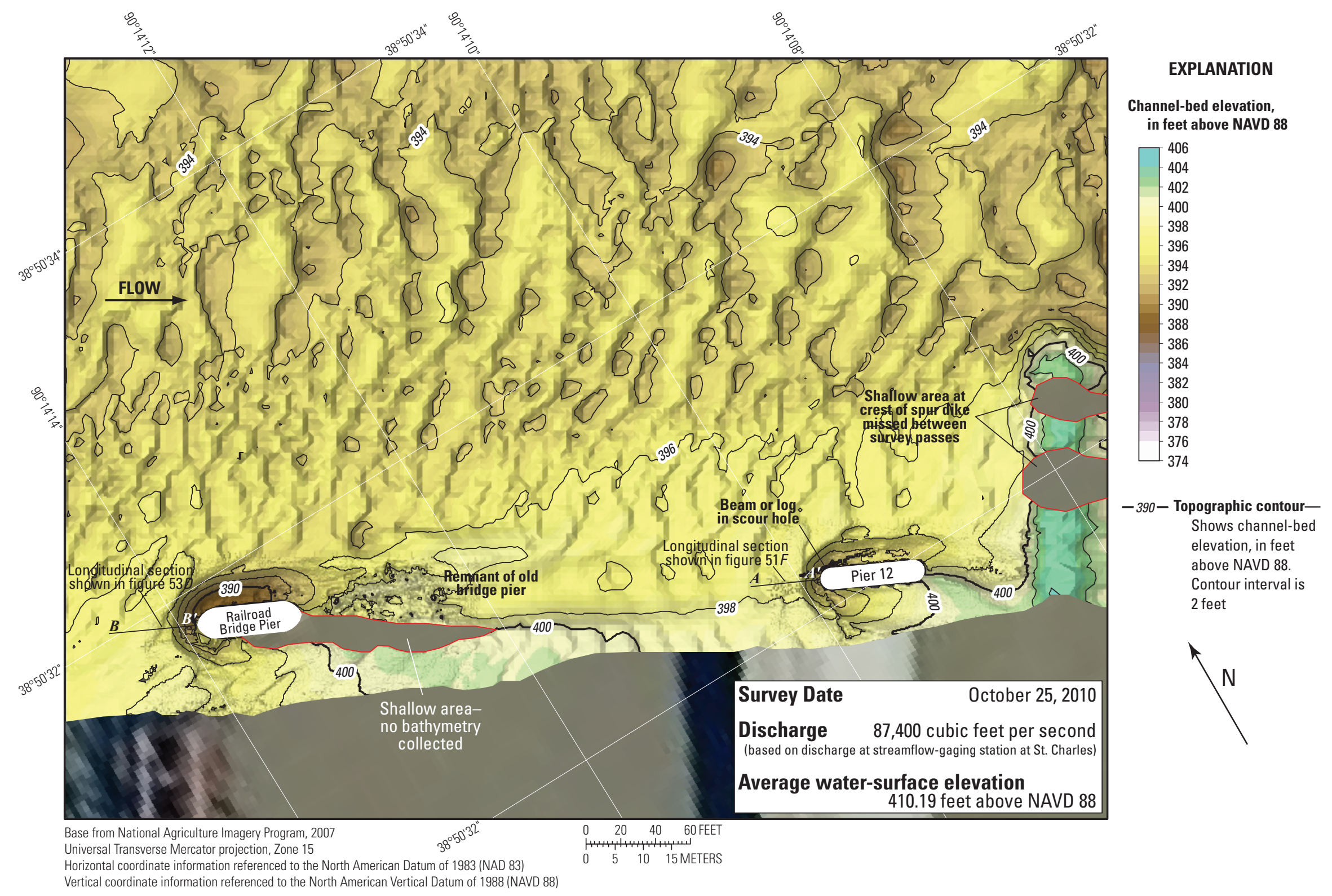

Figure 32. Bathymetric survey of the Missouri River channel in the vicinity of the right main channel pier of structure A3047 on U.S. Highway 67 near St. Louis, Missouri. 


\section{Structure A1500 on Interstate 55}

Structure A1500 is a single bridge on Interstate 55 on the eastern side of downtown St. Louis (figs. 1, 33). The survey was conducted on October 20,2010; the average water-surface elevation of the Mississippi River in the survey area determined by the RTK GPS tide solution was $396.54 \mathrm{ft}$ (table 5). Flow on the Mississippi River was about 277,000 $\mathrm{ft}^{3} / \mathrm{s}$ during the survey (table 5).

The survey area was about 4,590 ft long and about 1,610 $\mathrm{ft}$ wide, extending essentially from bank to bank in the main channel (fig. 34). The upstream end of the survey area was about 1,790 $\mathrm{ft}$ upstream from the centerline of structure A1500 (figs. 33, 34). The surveyed channel-bed elevations generally ranged from about 341 to $369 \mathrm{ft}$ (5 to 95 percentile range of the bathymetric data), except at the highway and railroad bridge piers, and in the vicinity of a natural constriction and rock outcrop downstream from the MacArthur railroad bridge (figs. 33, 34). The channel thalweg was along the left (east) bank throughout the surveyed area, and the channel was filled with numerous large, medium, and small dune features and ripples (fig. 34). The natural constriction of the left bank downstream from the MacArthur railroad bridge is caused by a substantial outcrop of rock, and resulted in a localized deep hole with a minimum channel elevation of about $333 \mathrm{ft}$ on the left side of the channel (fig. 34). A similar constriction appears to be present on the right (west) side of the channel, which caused another localized hole with a minimum channel elevation of about $342 \mathrm{ft}$ (fig. 34). A rock outcrop or submerged object on the channel bottom caused another localized deep hole downstream from the constriction, with a minimum channel elevation of about $334 \mathrm{ft}$ (fig. 34).

There was no observed scour hole in the immediate vicinity of the left bank pier (pier 5, fig. 35A). The upper left bank is covered with gravel and cobble-sized revetment that may extend to the toe of the bank and will limit or prevent scour at this pier. The channel thalweg at the toe of the left bank had a minimum elevation of about $349 \mathrm{ft}$ immediately downstream from pier 5 (fig. $35 \mathrm{~A}$ ), which is about $7 \mathrm{ft}$ below the bottom of the seal course elevation of $356.00 \mathrm{ft}$ (fig. 36; table 7); however, the thalweg is more than $100 \mathrm{ft}$ to the right from the pier (fig. 35A). Information from bridge plans indicates that pier 5 is founded on shafts drilled $7 \mathrm{ft}$ into bedrock, with about $62 \mathrm{ft}$ of bed material between the channel thalweg and bedrock near the bridge, and about $95 \mathrm{ft}$ of bed material between the bed and bedrock at the nose of the pier (fig. 36; table 7).

A moderate scour hole was present in the vicinity of the left main channel pier (pier 4, fig. 35B) with a minimum elevation of about $341 \mathrm{ft}$, about $10 \mathrm{ft}$ below the average channel bed immediately upstream from the pier (fig. $35 B$; table 7). Information from bridge plans indicates that pier 4 is founded on shafts drilled $7 \mathrm{ft}$ into bedrock, with about $44 \mathrm{ft}$ of bed material between the bottom of the scour hole and bedrock (fig. 36; table 7). A point cloud visualization of the multibeam depth points obtained during the survey clearly show the exposed footing and seal course of pier 4 (fig. 37).

Similarly, a moderate scour hole was present in the vicinity of the right main channel pier (pier 3, fig. 38A) with a minimum elevation of about $351 \mathrm{ft}$, about $11 \mathrm{ft}$ below the average channel bed immediately upstream from the pier (fig. 38A; table 7). Information from bridge plans indicates that pier 3 also is founded on shafts drilled $7 \mathrm{ft}$ into bedrock, with about $27 \mathrm{ft}$ of bed material between the bottom of the scour hole and bedrock (fig. 36; table 7).

As with the left bank pier, there was no observable scour hole at the right bank pier (pier 2, fig. 38B). The right bank is covered with granite paving stone revetment under the bridge and upstream that extends to the toe of the bank and will limit or prevent scour at this pier. The minimum elevation at the toe of the right bank near pier 2 was about $360 \mathrm{ft}$ (fig. 38B), which is about $4 \mathrm{ft}$ above the bottom of the footing elevation of $355.63 \mathrm{ft}$ (fig. 36); however, the thalweg is nearly $90 \mathrm{ft}$ to the left from the pier (fig. 38B). Information from bridge plans indicates that pier 2 is founded on footings on bedrock, with about $10 \mathrm{ft}$ of bed material between the channel bed and bedrock at the toe of the bank, and about $28 \mathrm{ft}$ of bed material between the bed and bedrock at the nose of the pier (fig. 36; table 7).

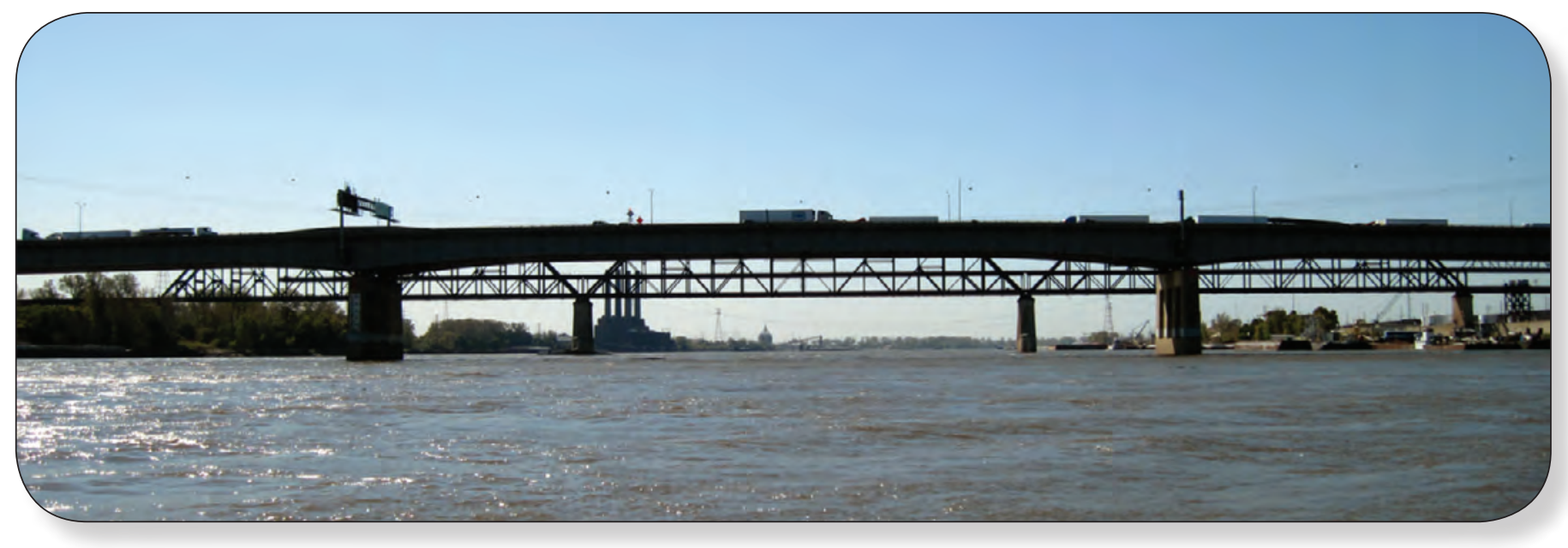

Structure A1500 on Interstate 55. The MacArthur railroad bridge is in the background. 


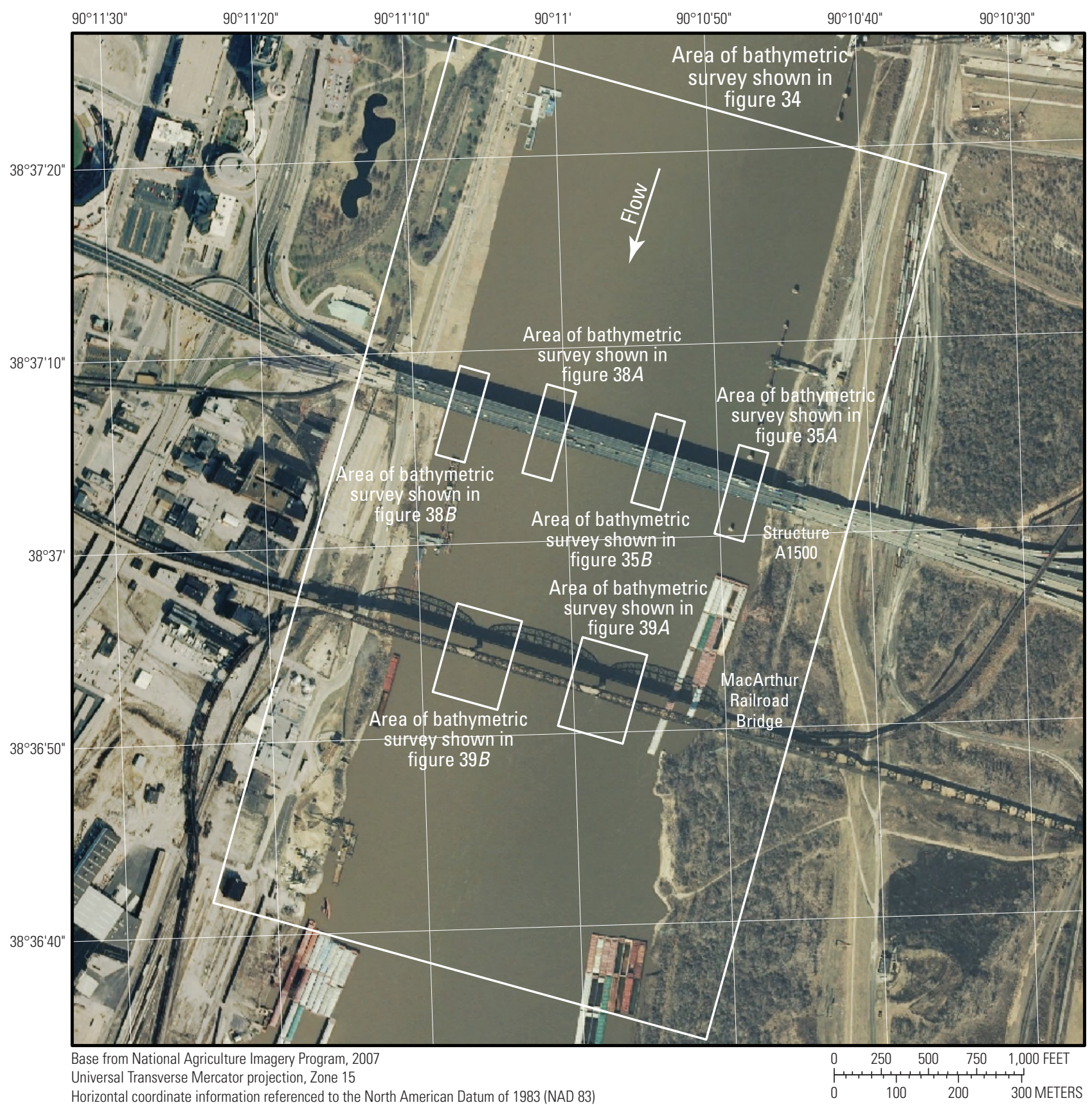

Figure 33. Location of the bathymetric survey area on the Mississippi River near structure A1500 on Interstate 55 near St. Louis, Missouri.

Substantial scour holes were observed at the MacArthur railroad bridge piers downstream from structure A1500 (fig. 39). In the vicinity of the left main channel pier (fig. 39A), the hole had a minimum elevation of $321 \mathrm{ft}$ at the nose of the pier, which was the minimum elevation in the entire survey area (table 5) and about $40 \mathrm{ft}$ below the average channel bed immediately upstream from the pier (fig. 39A). The size of this scour hole is substantially affected by a partially sunken barge trapped on the nose of the pier (fig. 40). In the vicinity of the right main channel pier (fig. 39B), the hole had a minimum elevation of $333 \mathrm{ft}$ at the nose of the pier, about $31 \mathrm{ft}$ below the average channel bed immediately upstream from the pier (fig. 39B). 


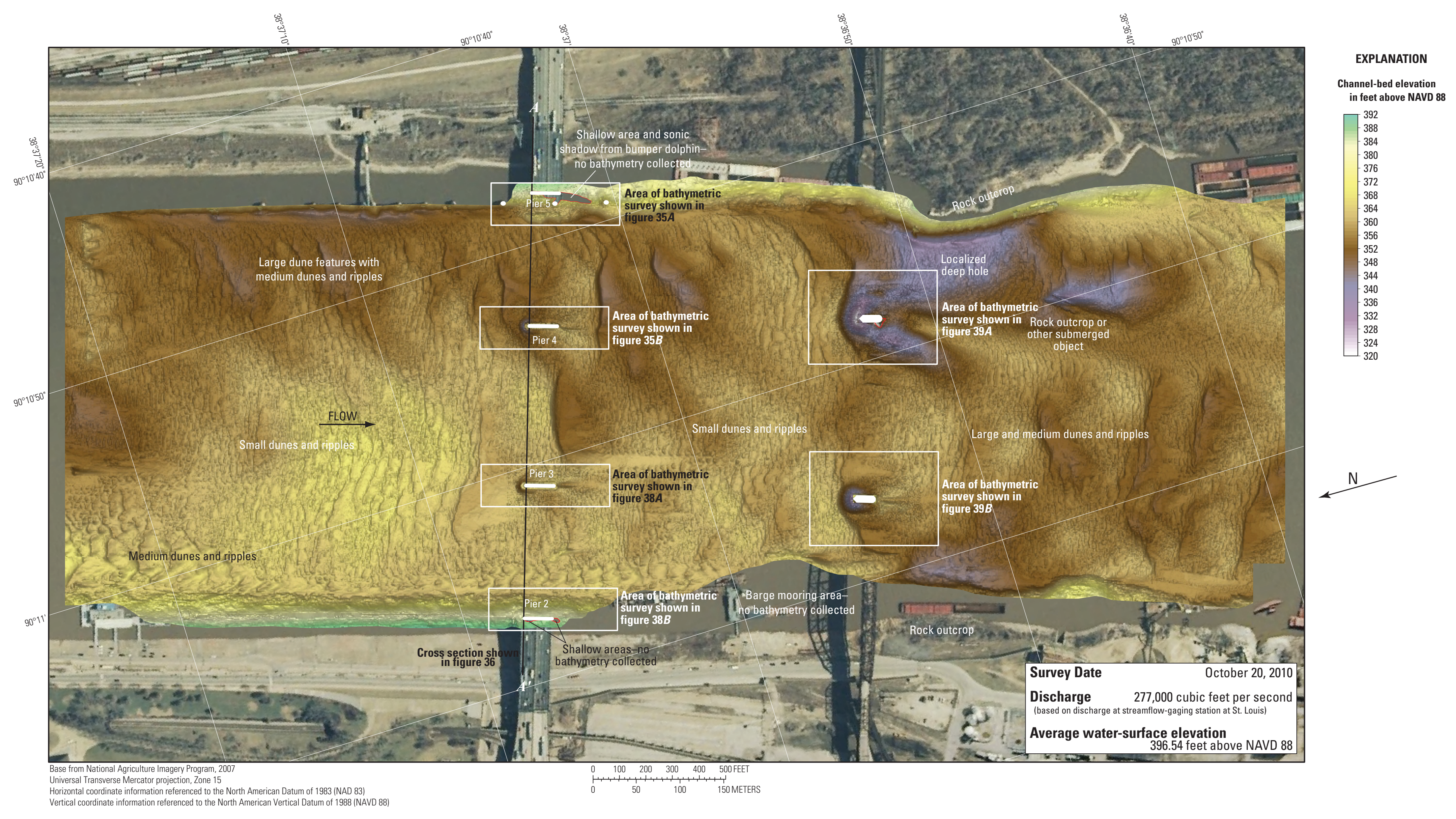

Figure 34. Bathymetric survey of the Mississippi River channel in the vicinity of structure A1500 on Interstate 55 near St. Louis, Missouri. 


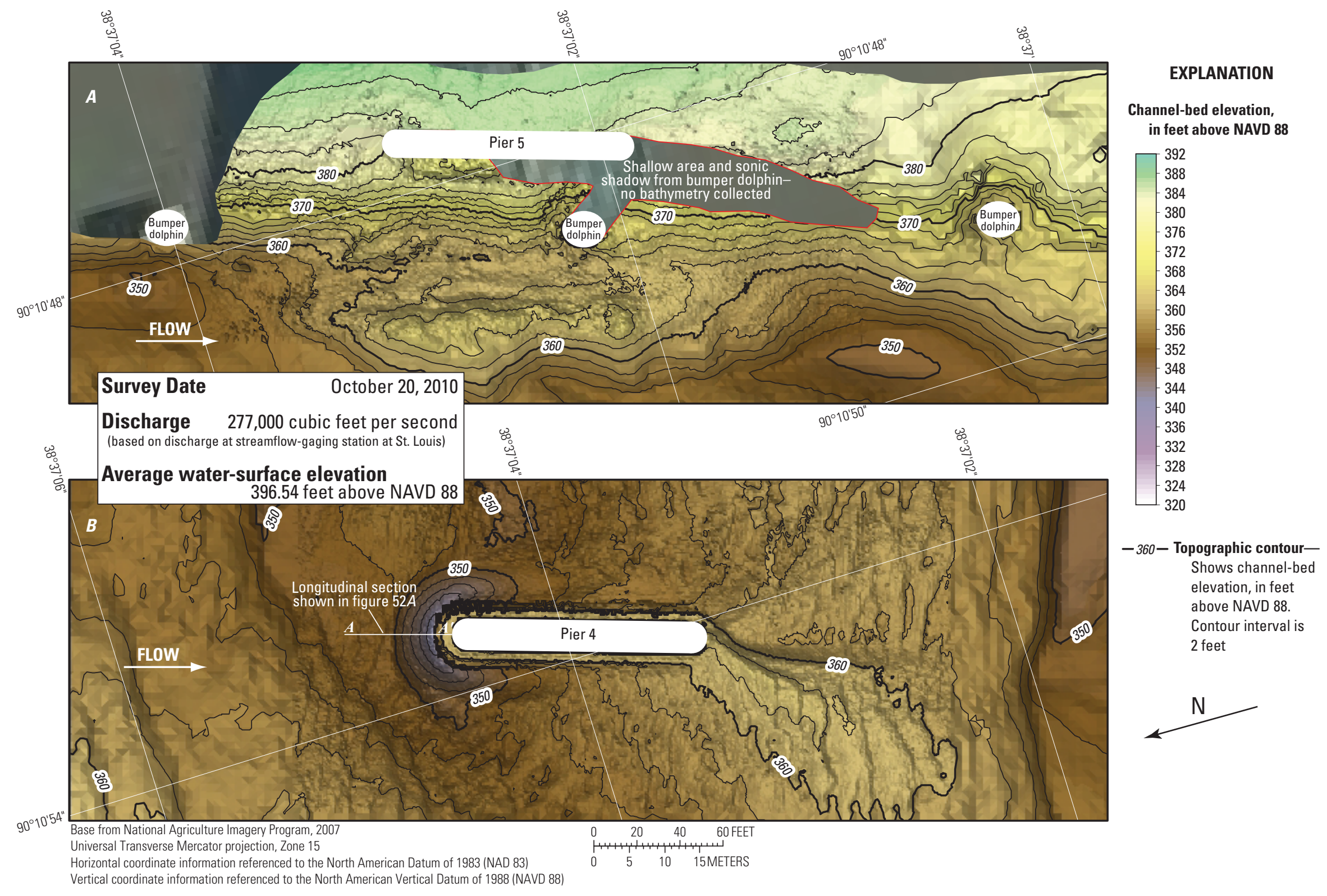

Figure 35. Bathymetric survey of the Mississippi River channel in the vicinity of the $A$, left bank, and $B$, left main channel piers of structure A1500 on Interstate 55 near St. Louis, Missouri. 


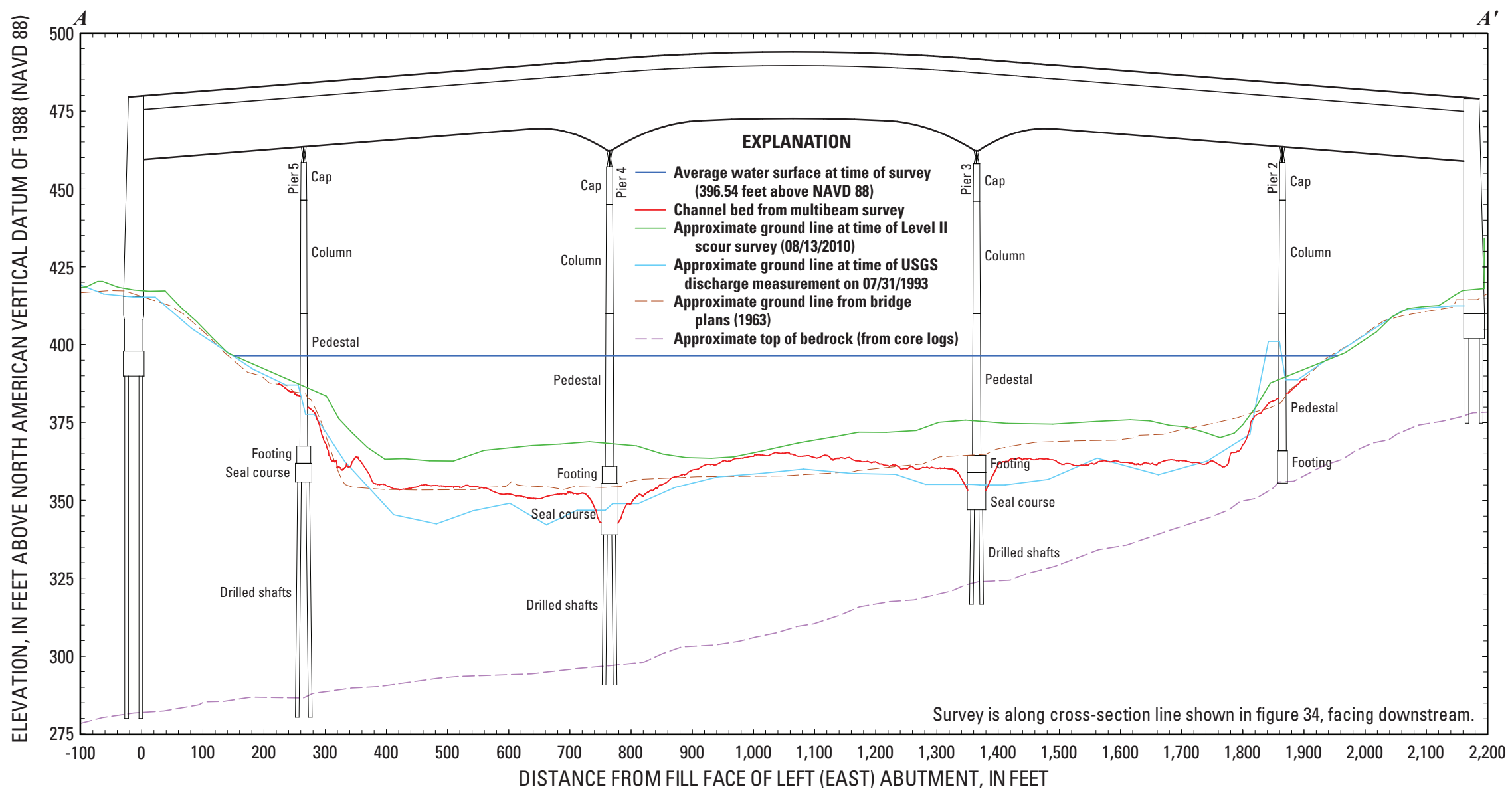

Figure 36. Key features, substructural and superstructural details, and surveyed channel bed of structure A1500 on Interstate 55 over the Mississippi River near St. Louis, Missouri. 
Table 7. Results near piers from surveys on the Mississippi River near St. Louis, Missouri, from October 19-20, 2010.

[MoDOT, Missouri Department of Transportation; ft, feet; --, not known/applicable; all elevations are in feet above the North American Vertical Datum of 1988]

\begin{tabular}{|c|c|c|c|c|c|c|c|c|c|c|c|}
\hline \multirow[b]{2}{*}{$\begin{array}{c}\text { MoDOT } \\
\text { structure } \\
\text { number } \\
\text { (fig. 1) }\end{array}$} & \multirow[b]{2}{*}{$\begin{array}{c}\text { MoDOT } \\
\text { pier number }\end{array}$} & \multicolumn{4}{|c|}{ Foundation information } & \multirow{2}{*}{$\begin{array}{l}\text { Approximate } \\
\text { minimum } \\
\text { elevation in } \\
\text { scour hole } \\
\text { near pier } \\
\text { (ft) }\end{array}$} & \multirow{2}{*}{$\begin{array}{l}\text { Approximate } \\
\text { elevation of } \\
\text { scour hole } \\
\text { at upstream } \\
\text { pier face } \\
\text { (ft) }\end{array}$} & \multirow{2}{*}{$\begin{array}{l}\text { Approximate } \\
\text { elevation } \\
\text { of bedrock } \\
\text { near pier } \\
\text { (ft) }\end{array}$} & \multirow{2}{*}{$\begin{array}{c}\text { Approximate } \\
\text { distance } \\
\text { between } \\
\text { bottom of } \\
\text { scour hole } \\
\text { and bedrock } \\
\text { (ft) }\end{array}$} & \multirow{2}{*}{$\begin{array}{c}\text { Depth } \\
\text { of scour } \\
\text { hole from } \\
\text { upstream } \\
\text { channel bed } \\
\text { (ft) }\end{array}$} & \multirow[b]{2}{*}{$\begin{array}{c}\text { Approximate } \\
\text { frontal slope } \\
\text { of scour hole } \\
\text { (ft/ft) }\end{array}$} \\
\hline & & Type & $\begin{array}{l}\text { Width } \\
\text { (ft) }\end{array}$ & $\begin{array}{c}\text { Penetration } \\
\text { into bedrock } \\
\text { (ft) }\end{array}$ & $\begin{array}{c}\text { Seal course } \\
\text { bottom } \\
\text { elevation } \\
\text { (ft) }\end{array}$ & & & & & & \\
\hline \multirow[t]{4}{*}{ A1500 } & 5 & Drilled shaft & 27 & 7 & 356.00 & 349 & 382 & 287 & 95 & 0 & $--^{\mathrm{b}}$ \\
\hline & 4 & Drilled shaft & 28 & 7 & 339.00 & 341 & 341 & 297 & 44 & 10 & 1.85 \\
\hline & 3 & Drilled shaft & 30 & 7 & 347.00 & 351 & 351 & 324 & 27 & 11 & 1.88 \\
\hline & 2 & Footing & 16 & 1 & -- & 360 & 384 & 356 & 28 & 0 & $--^{b}$ \\
\hline \multirow[t]{5}{*}{ A4936 } & 8 & Piling & 36 & 1 & 353.00 & 357 & 357 & 297 & 60 & 13 & 1.81 \\
\hline & 9 & Piling & 36 & 1 & 353.00 & 350 & 350 & 297 & 53 & 16 & 1.80 \\
\hline & 10 & Piling & 36 & 1 & 348.00 & 355 & 364 & 294 & 70 & 0 & $--{ }^{b}$ \\
\hline & 11 & Piling & 36 & 1 & 344.00 & 351 & 360 & 293 & 67 & 0 & $--^{b}$ \\
\hline & ${ }^{\mathrm{c}} 12$ & Piling & 56 & 1 & 328.00 & 350 & 350 & 295 & 55 & 9 & 1.82 \\
\hline \multirow[t]{4}{*}{ A1850 } & 8 & Piling & 36 & 1 & 353.00 & 368 & 368 & 297 & 71 & 5 & 2.02 \\
\hline & 9 & Piling & 36 & 1 & 353.00 & 355 & 355 & 297 & 58 & 9 & 2.72 \\
\hline & 10 & Piling & 36 & 1 & 348.00 & 347 & 366 & 294 & 72 & 0 & $--^{b}$ \\
\hline & 11 & Piling & 36 & 1 & 344.00 & 353 & 361 & 293 & 68 & 0 & $--^{\mathrm{b}}$ \\
\hline
\end{tabular}

${ }^{a}$ The point of lowest elevation in the scour hole near the bridge pier, not necessarily at the upstream pier face.

${ }^{b}$ Unable to determine slope because no definitive scour hole was present.

${ }^{\mathrm{c}}$ Pier 12 is a single continuous pier that extends between structures A4936 and A1850. Therefore, results shown for this pier are the same for both structures. 


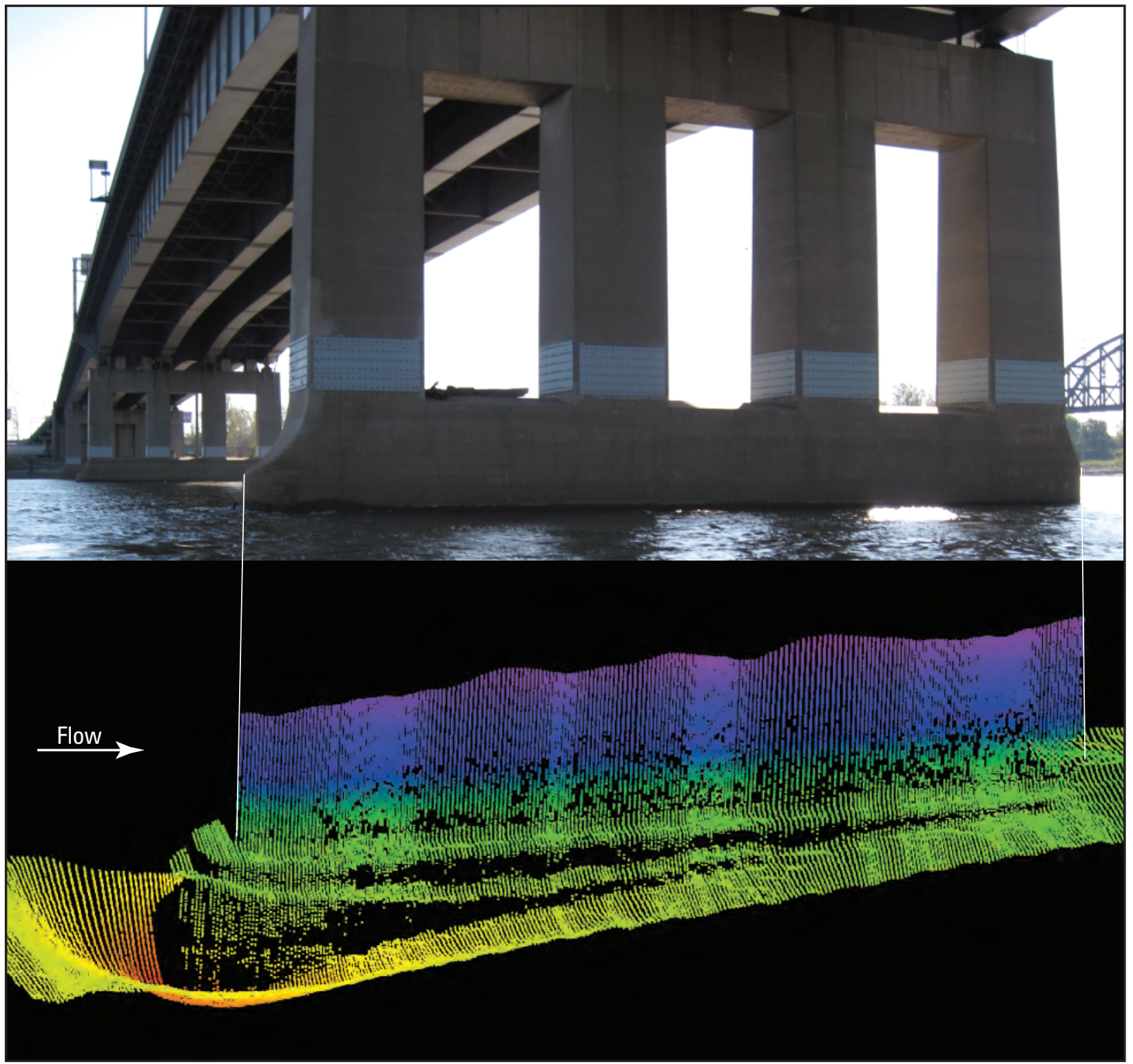

\section{EXPLANATION}

Elevation of point, in feet above the North American

Vertical Datum of 1988

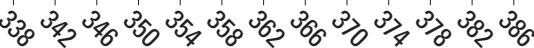

Photograph as shown is of the right main channel pier (pier 3) from the west side, and is shown for visualization purposes only.

Figure 37. Point cloud visualization of the channel bed and right (west) side of the left main channel pier (pier 4) of structure A1500 on Interstate 55 over the Mississippi River near St. Louis, Missouri. 


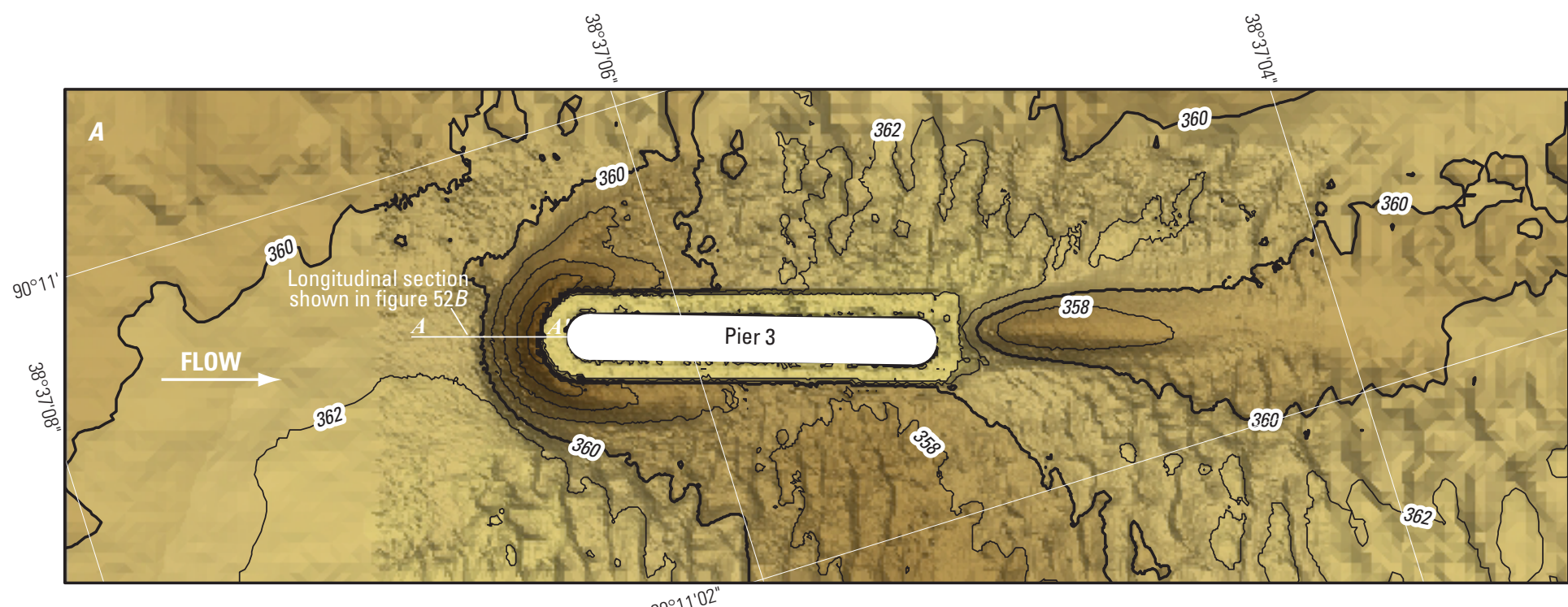

EXPLANATION

Channel-bed elevation, in feet above NAVD 88

\begin{tabular}{|l}
\hline 392 \\
-388 \\
-384 \\
-380 \\
-376 \\
-372 \\
-368 \\
-364 \\
-360 \\
-356 \\
-352 \\
-348 \\
-344 \\
-340 \\
-336 \\
-332 \\
328 \\
-324 \\
320
\end{tabular}

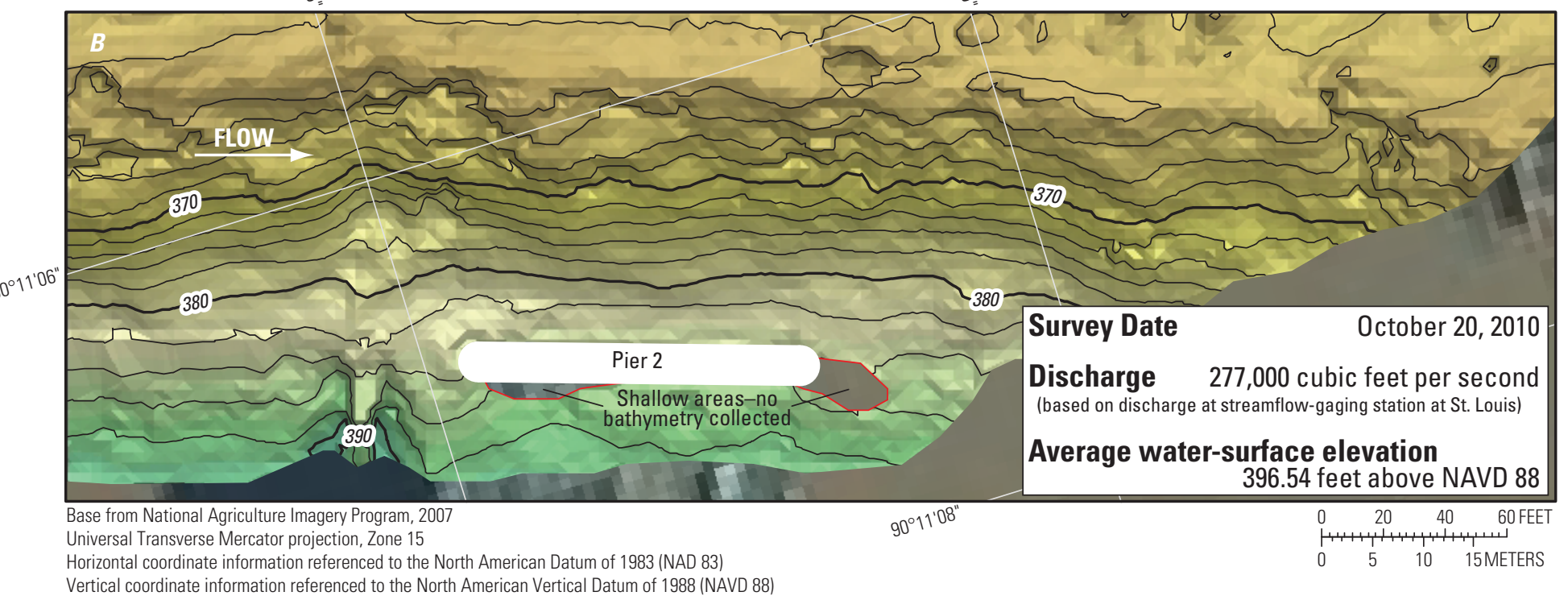

- 360- Topographic contourShows channel-bed elevation, in feet above NAVD 88. Contour interval is 2 feet

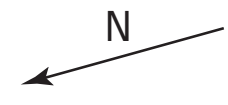

Figure 38. Bathymetric survey of the Mississippi River channel in the vicinity of the $A$, right main channel and, $B$, right bank piers of structure $A 1500$ on Interstate 55 near St. Louis, Missouri. 


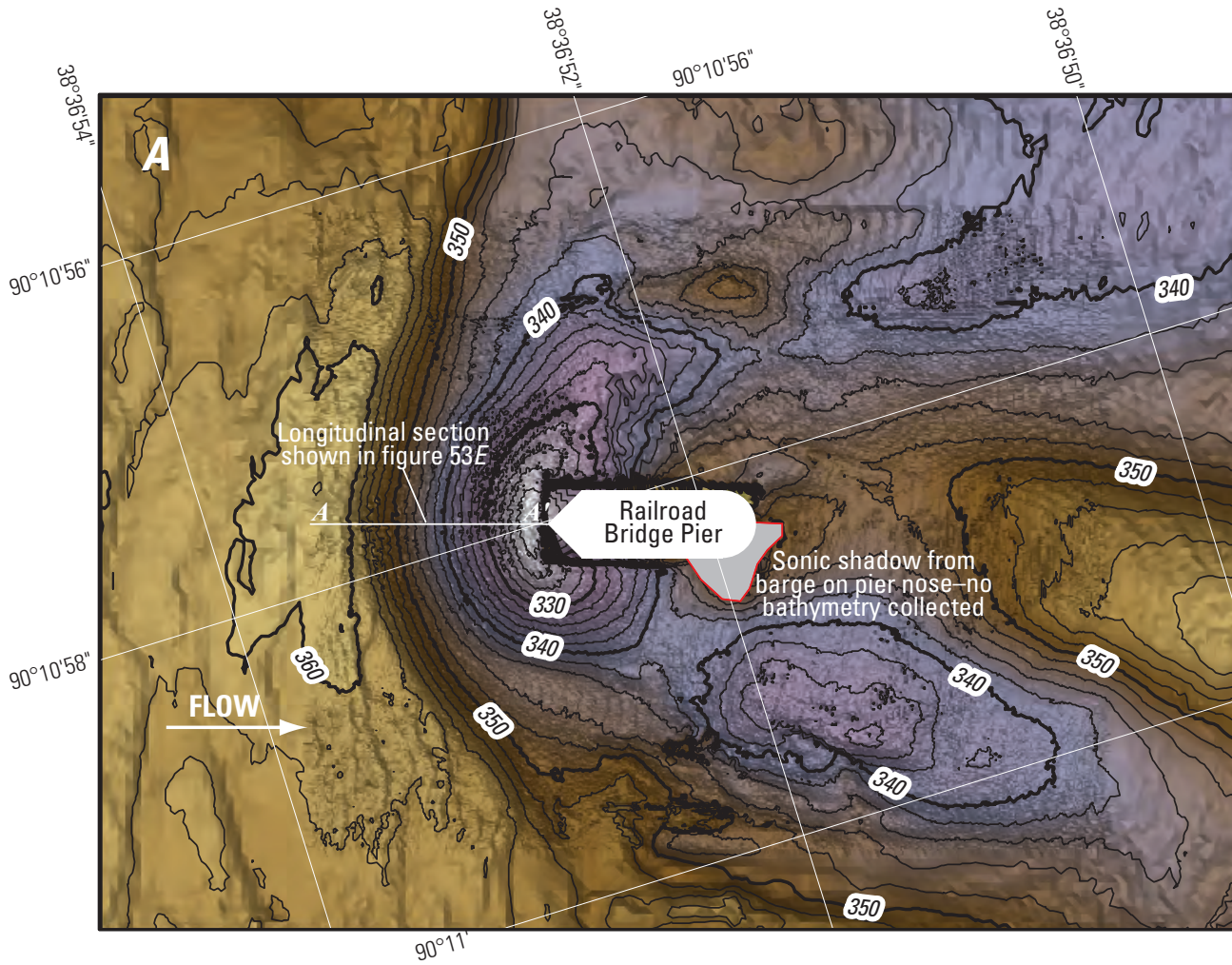

\section{EXPLANATION}

Channel-bed elevation, in feet above NAVD 88
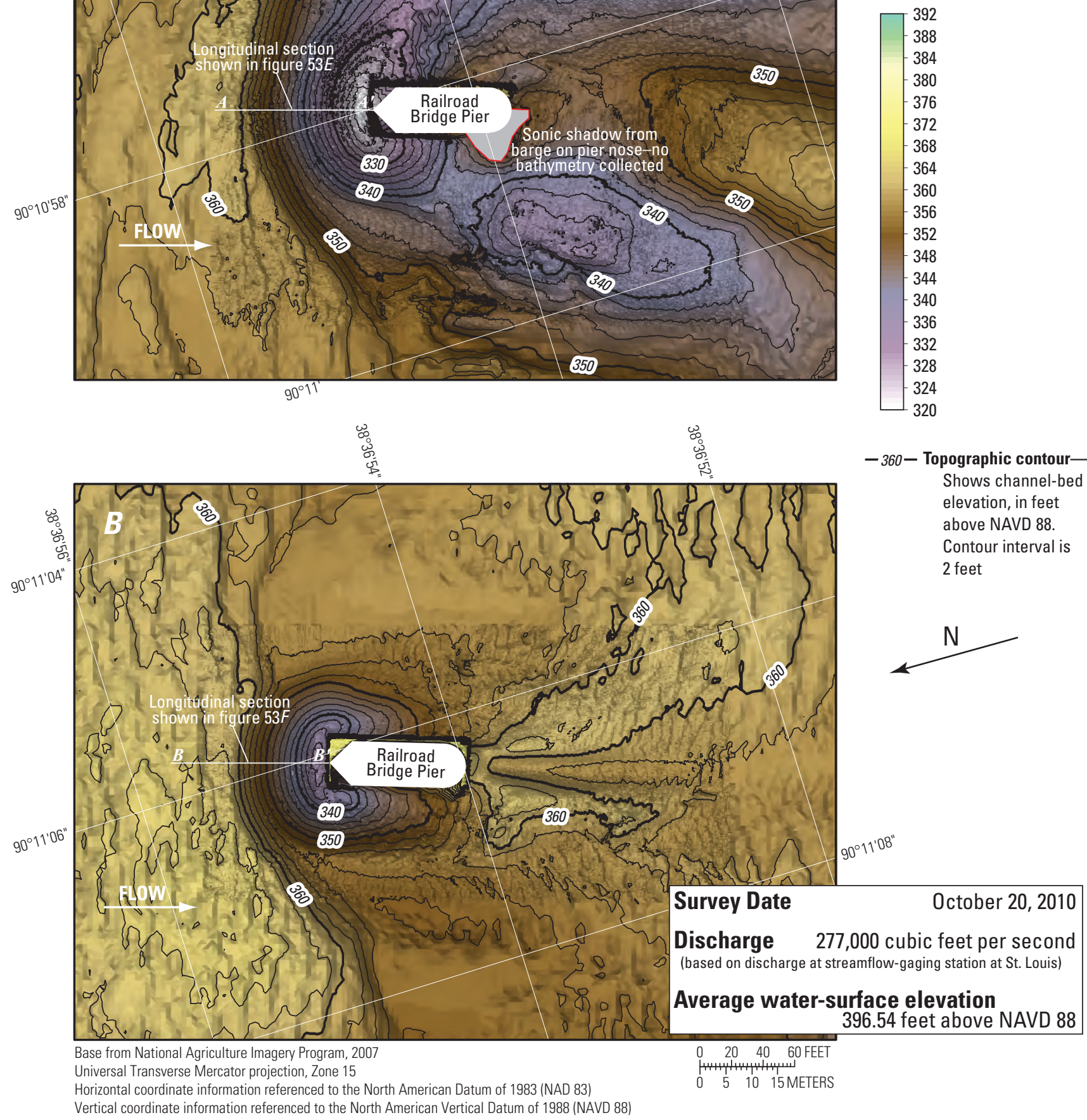

Figure 39. Bathymetric survey of the Mississippi River channel in the vicinity of the $A$, left and $B$, right main channel piers of the MacArthur Railroad Bridge downstream from structure A1500 on Interstate 55 near St. Louis, Missouri. 


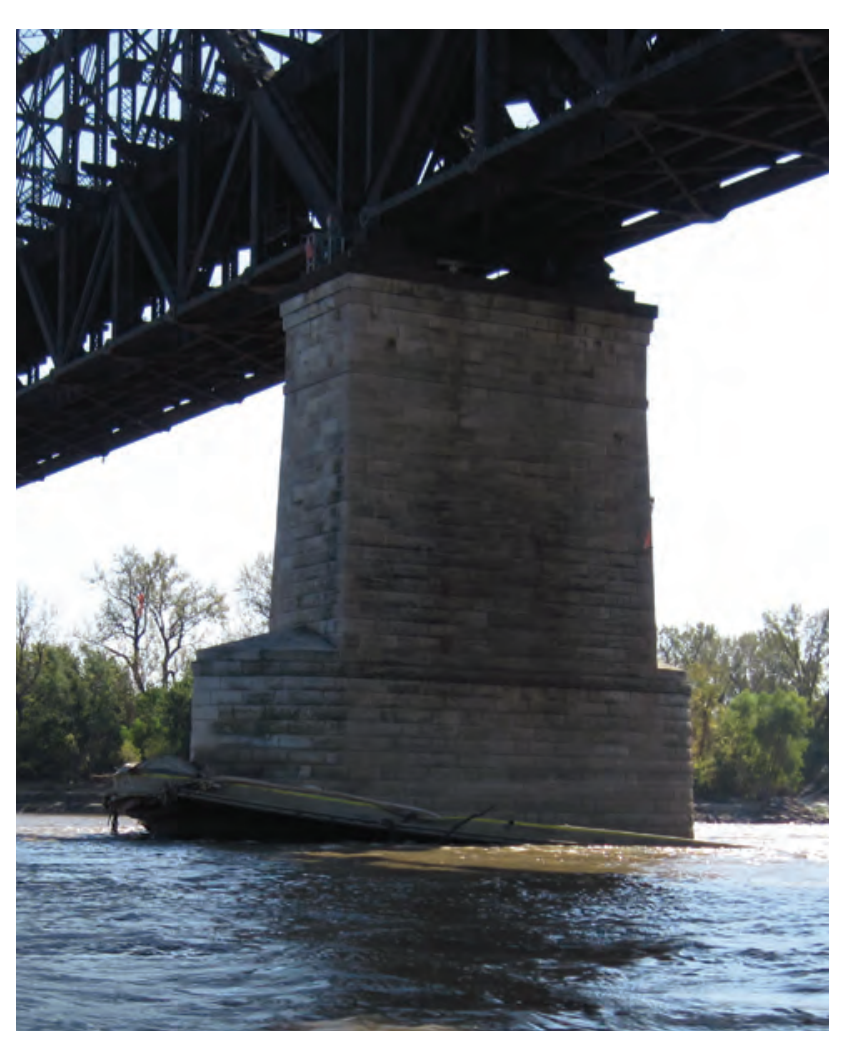

Figure 40. A partially sunken barge trapped on the nose of the left main channel pier of the MacArthur railroad bridge over the Mississippi River downstream from structure A1500 on Interstate 55 near St. Louis, Missouri.
The channel bed appears to have been dynamic through time. The multibeam surveyed channel bed was substantially lower than the channel bed from the Level II scour survey in August 2010 (Richard Huizinga, unpub. data, 2010) except between piers 3 and 4 (fig. 36). Part of this difference arises from the fact that the Level II survey across the channel was made downstream from structure A1500, whereas the bathymetric survey cross-section line was along the upstream face. Between piers 4 and 5, the multibeam surveyed channel bed was essentially the same as the ground line from bridge plans at the time of bridge construction in 1963, whereas it generally is higher than and lower than the 1963 ground line from bridge plans between piers 3 and 4 and piers 2 and 3, respectively (fig. 36). In an analysis of cross-section information obtained during discharge measurements from a monorail car at structure A1500, Huizinga (2009) noted the extreme dynamic nature of the channel bed before, during, and after the 1993 flood. The approximate ground line from bridge plans at the time of a discharge measurement made on July 31,1993 , near the peak of the flood also is shown in figure 36; this section had the lowest elevations of all of the measurement sections during the 1993 flood (Huizinga, 2009). 


\section{Structures A4936 and A1850 on Interstate 255}

Structures A4936 and A1850 are dual bridges on Interstate 255 on the southeastern side of the St. Louis metropolitan area, between Mehlville, Missouri, and Columbia, Illinois (figs. 1, 41). The survey was conducted on October 19, 2010, and the average water-surface elevation of the Mississippi River in the survey area determined by the RTK GPS tide solution was $391.61 \mathrm{ft}$ (table 5). Flow in the Mississippi River was about $288,000 \mathrm{ft}^{3} / \mathrm{s}$ during the survey (table 5).

The survey area was about 4,590 ft long and about 1,970 $\mathrm{ft}$ wide, extending from shallow areas on the left to the right bank in the main channel (fig. 42). The upstream end of the survey area was about $1,970 \mathrm{ft}$ upstream from the centerline between structures A4936 and A1850 (figs. 41, 42). The channel-bed elevations ranged from about 352 to $371 \mathrm{ft}$ for most of the surveyed area (5 to 95 percentile range of the bathymetric data), except in the localized deep hole near the large L-head dike on the left side of the channel downstream from the bridges, which had a minimum elevation of $323 \mathrm{ft}$ (fig. 42). A shallow channel thalweg was along the right (west) bank (fig. 42). Larger dune features were detected along the rock outcrops on the right side of the survey area; the remainder of the channel was filled with medium and small dunes and ripples (fig. 42).

Substantial scour holes were present in the vicinity of piers 8 and 9 of upstream structure A4936, and moderate scour holes were present in the vicinity of piers 8 and 9 of downstream structure A1850 (fig. 43). Near pier 8 of upstream structure A4936, the scour hole had a minimum elevation of about $357 \mathrm{ft}$, about $13 \mathrm{ft}$ below the average channel bed immediately upstream from the pier, and $4 \mathrm{ft}$ above the bottom of the seal course elevation of $353.00 \mathrm{ft}$ (fig. 43; table 7). Near pier 9 of upstream structure A4936, the scour hole had a minimum elevation of about $350 \mathrm{ft}$, about $16 \mathrm{ft}$ below the average channel bed immediately upstream from the pier, and $3 \mathrm{ft}$ below the bottom of the seal course elevation of $353.00 \mathrm{ft}$ (fig. 43; table 7). At downstream structure A1850, the scour hole near pier 8 had a minimum elevation of $368 \mathrm{ft}$ (about $5 \mathrm{ft}$ below the average channel bed immediately upstream), and the scour hole near pier 9 had a minimum elevation of $355 \mathrm{ft}$ (about $9 \mathrm{ft}$ below the average channel bed immediately upstream). Information from bridge plans indicates that structures A4936 and A1850 are exactly the same in cross section for the part of the bridges across the main channel, which permits the cross-section data for each bridge to be examined together (fig. 44). Bridge plans indicate that piers 8 and 9 are founded on piles driven to refusal on bedrock at both structures, and there is about $60 \mathrm{ft}$ of bed material between the bottom of the scour hole and bedrock at pier 8 of upstream structure A4936 and about $53 \mathrm{ft}$ of bed material between the bottom of the scour hole and bedrock at pier 9 of upstream structure A4936 (fig. 44; table 7). A point cloud visualization of the multibeam depth points obtained during the survey clearly show the exposed footing and seal course of pier 9 of both structures A4936 and A1850 (fig. 45).

A moderate scour hole was present upstream from pier 12 with a minimum elevation of about $350 \mathrm{ft}$, about $9 \mathrm{ft}$ below the average channel bed immediately upstream from the pier, but 22 feet above the bottom of the seal course elevation of $328.00 \mathrm{ft}$ (fig. 43; table 7). Information from bridge plans indicates that pier 12 is founded on piles driven to refusal on bedrock, with about $55 \mathrm{ft}$ of bed material between the bottom of the scour hole and bedrock (fig. 44; table 7). A point-cloud visualization of the multibeam-depth points obtained during the survey shows the top of the exposed footing of pier 12 (fig. 46).

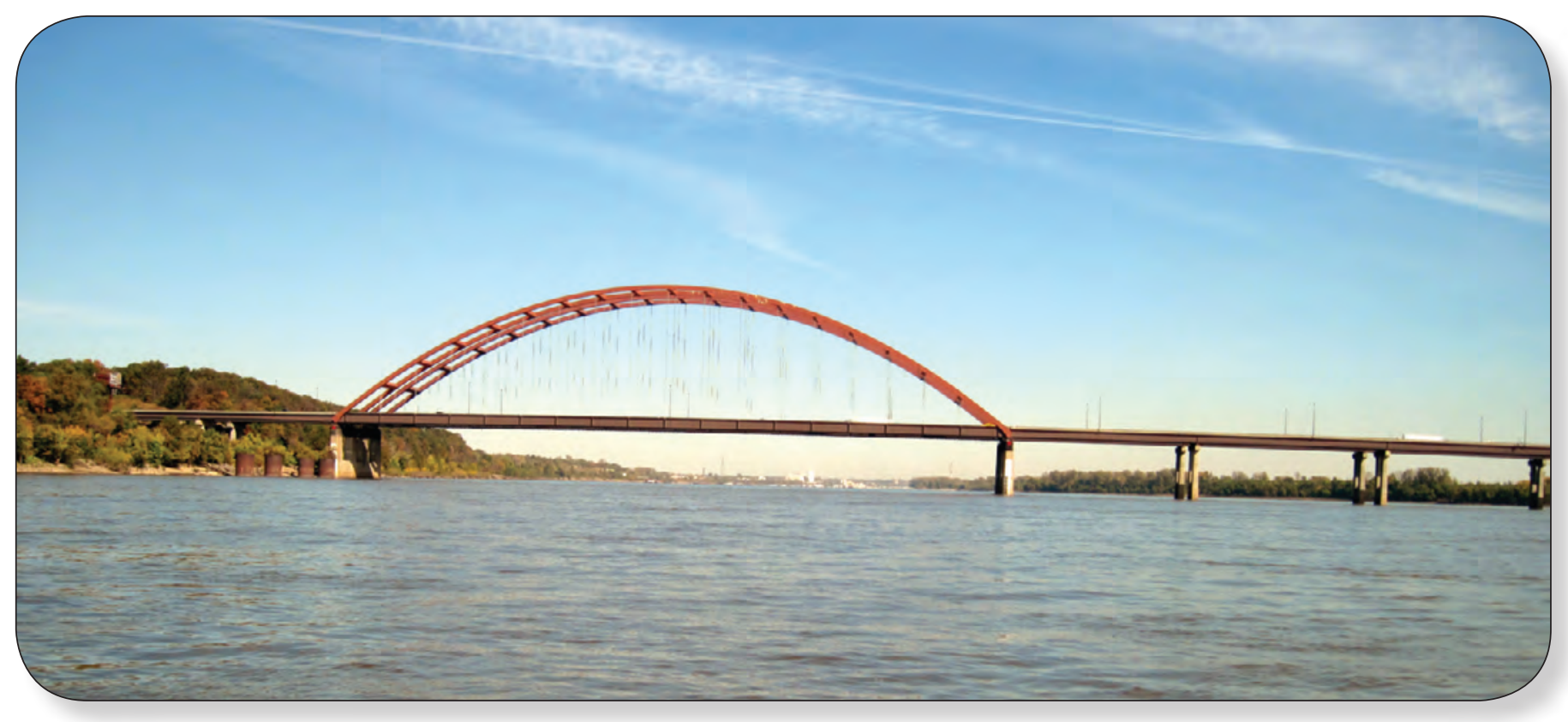

Structures A4936 and A1850 on Interstate 255. Structure A1850 is in the foreground and A4936 is in the background. 


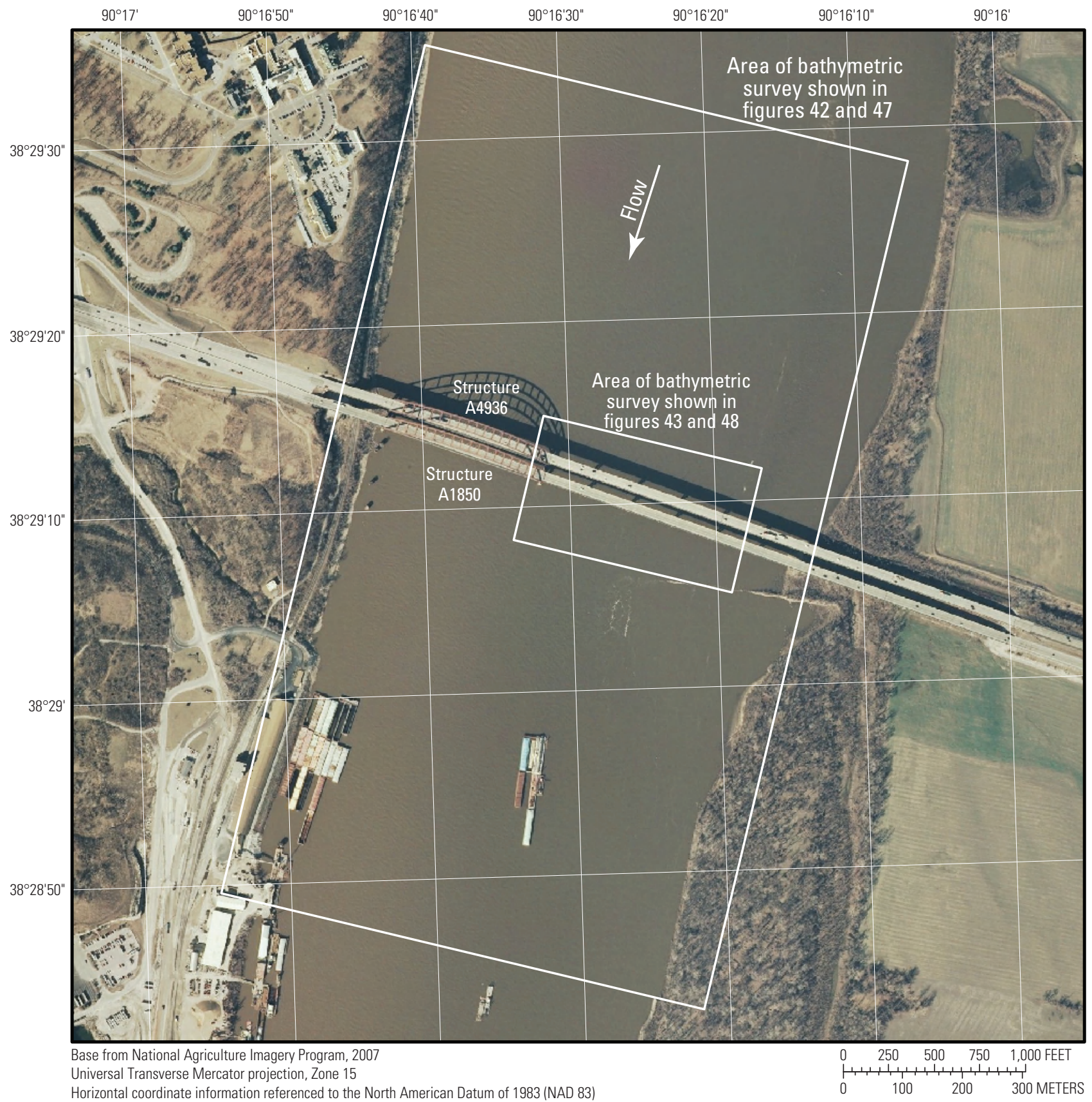

Figure 41. Location of the bathymetric survey area on the Mississippi River near structures A4936 and A1850 on Interstate 255 near St. Louis, Missouri. 


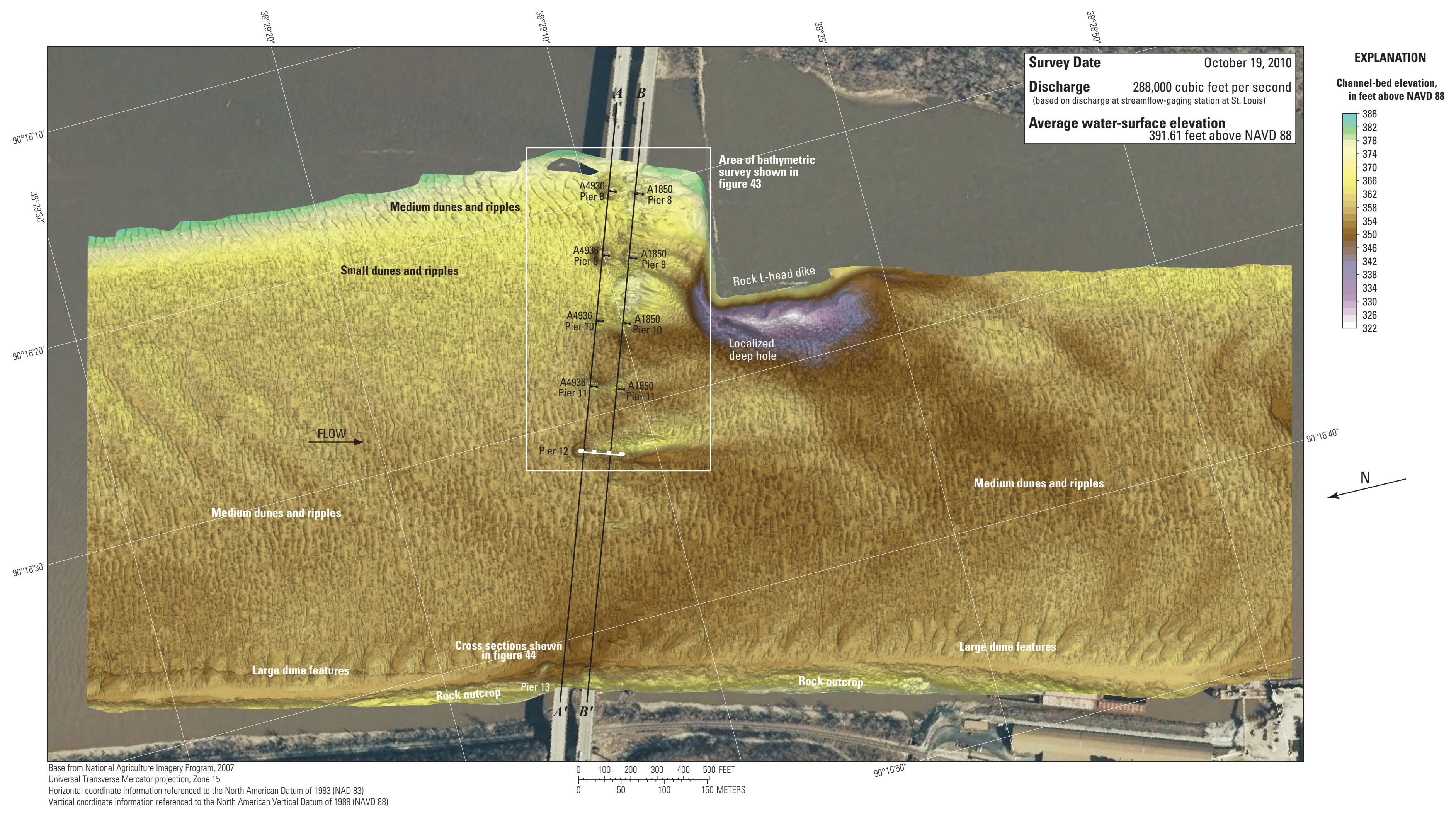

Figure 42. Bathymetric survey of the Mississippi River channel in the vicinity of structures A4936 and A1850 on Interstate 255 near St. Louis, Missouri. 


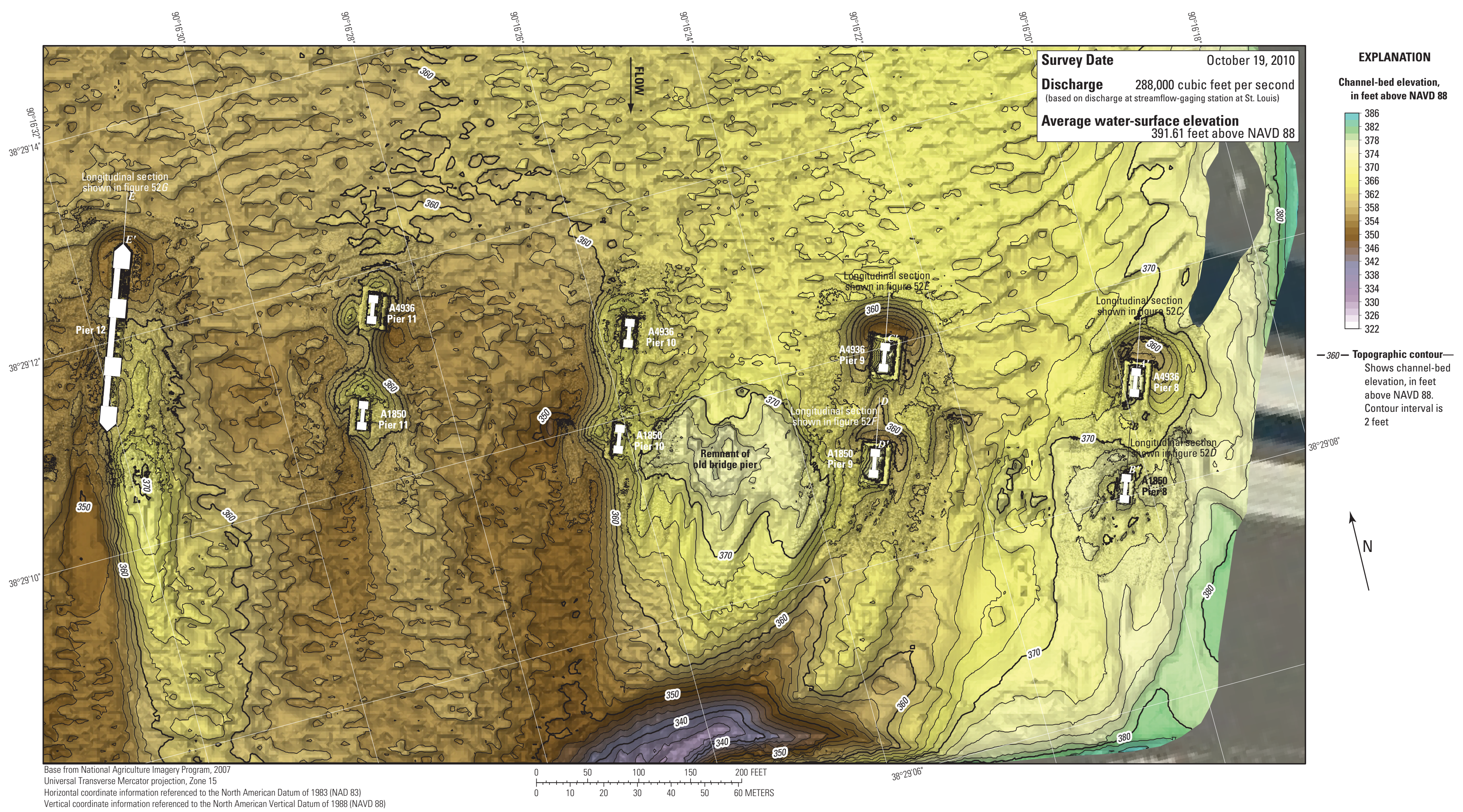

Figure 43. Bathymetric survey of the Mississippi River channel in the vicinity of the main channel piers of structures A4936 and A1850 on Interstate 255 near St. Louis, Missouri. 

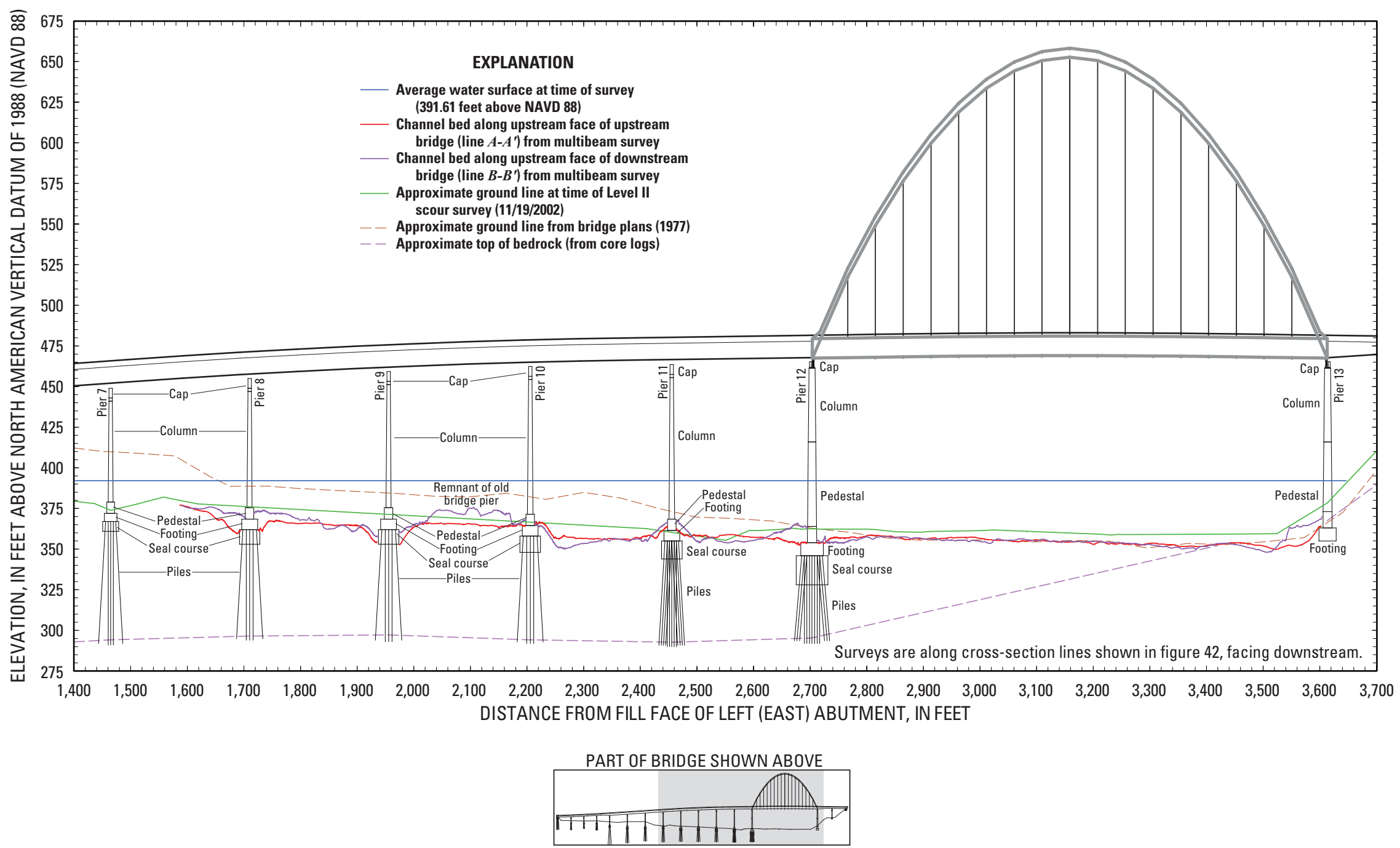

Figure 44. Key features, substructural and superstructural details, and surveyed channel bed along the upstream face of each bridge of identical structures A4936 and A1850 on Interstate 255 over the Mississippi River near St. Louis, Missouri. 
Scour holes were not observed upstream from piers 10 and 11 of either structure A4936 or A1850 (fig. 43); in fact, the surveyed channel bed appears to be aggraded in the vicinity of these piers (fig. 44), which indicates riprap or some other scour-resistant material has been piled near the upstream faces of these piers; however, the side edges and downstream corners of the footings are apparent at pier 11 of both structures, and a local scour hole with a minimum elevation of $351 \mathrm{ft}$ was present near the downstream left corner of pier 11 of upstream structure A4936. The remnant of an old bridge pier was observed between piers 9 and 10 of downstream structure A1850 (figs. 43, 44).

The surveyed channel bed was approximately $5 \mathrm{ft}$ lower than the channel bed from the Level II scour survey in November 2002 (Huizinga and Rydlund, 2004) for most of the channel, except between piers 8 and 9 , and between piers 10 and 11 (fig. 44). In the main channel between piers 12 and 13 , the surveyed channel bed was essentially the same as the ground line from bridge plans at the time of construction in 1977 (fig. 44).

Real-time scour monitoring of the scour hole at pier 12 occurred at this site in 2008-2009 using fixed, single-beam acoustic transducers attached to the upstream and downstream nose of pier 12 (Rydlund, 2009). Bathymetric surveys of the area were performed at a variety of flow conditions as part of that study for verification of the fixed transducers; the part of the channel near the main channel piers is illustrated for three other multibeam scans on October 2-3, 2008, May 12-13, 2009, and July 8, 2009 (Rydlund, 2009). The change in channel-bed elevation between the scans on October 19, 2010, and July 8, 2009 (fig. 47C), indicates numerous local areas of scour and deposition corresponding to the large dune features observed during the July 8, 2009, scan. Movement of these large dune features was captured by the fixed transducer on the downstream pier nose (Rydlund, 2009).

The change in channel-bed elevation between the scans on October 19, 2010, and May 12-13, 2009 (fig. 47B), also indicates several local areas of scour and deposition corresponding to the dune features observed during the May 12-13, 2009, scan, particularly the large dune observed in the channel upstream from the bridge (Rydlund, 2009). This dune was roughly 10-15 ft tall in May 2009, and movement of this large dune feature likely corresponds to the nearly 5 -ft pulse captured by the fixed transducer on the downstream pier nose in mid-June 2009 (Rydlund, 2009). The localized deep scour hole adjacent to the L-head dike in the October 19, 2010, scan (fig. 42) extended further downstream in May 2009 because of minor flooding at that time, resulting in substantial deposition observed downstream from the downstream tip of the L-head dike on the left bank (fig. 47B). This deposition had not yet occurred by the July 2009 scan, resulting in a similar deposition pattern for that scan (fig. 47C).

The change in channel-bed elevation between the scans on October 19, 2010, and October 2-3, 2008 (fig. 47A), indicates the channel bed had resumed a configuration similar to that observed in October 2008. No substantial channel bed changes were observed with the fixed transducer on the upstream pier nose from October to December 2008, and no changes were observed with the downstream transducer from October 2008 to early June 2009 (Rydlund, 2009). The channel thalweg was slightly deeper in October 2008, resulting in minor deposition along the right side of the channel and minor degradation along the upstream left side of the channel (fig. $47 A$ ). Substantial deposition had occurred in the shallow area on the extreme left side of the survey area between October 2008 and October 2010 (fig. 47A). The enlargement of the localized scour hole adjacent to the L-head dike in May 2009 persisted through the October 2010 scan, resulting in the area of substantial scour indicated near the dike (fig. 47A).

Comparison of the surveyed channel in the vicinity of the main channel piers on different dates revealed some areas where the channel bed remained the same through time, and other areas where the channel bed changed through time (fig. 48). The similarity of the channel-bed configuration is obvious between the scans on October 19,2010, and October 2-3, 2008 (fig. 48A). The substantial deposition on the left bank is apparent, as well as minor deposition and erosion in the immediate vicinity of piers 8,9 , and 10 ; however, the bed changes in the vicinity of the piers may be caused by positional errors, as there was no correction of the survey lines for the first two surveys (Oct 2-3, 2008, and May 12-13, 2009). The change in channel-bed elevation between the scans on October 19, 2010, and May 12-13, 2009, indicates nearly $9 \mathrm{ft}$ of erosion had occurred in the vicinity of piers 10 and 11 between these scans (fig. 48B). The lack of bed-elevation change in the immediate vicinity of pier 11 further substantiates the presence of riprap or some other scour-resistant material around this pier, although there is more change in the immediate vicinity of this pier between the October 19, 2010, and July 8, 2009, scans (fig. 48C). A comparison of the cross sections along the upstream bridge face for the four scans indicates the relative stability of the bed in the main channel between piers 12 and 13, as well as the substantial movement of the bed in the vicinity of pier 11 (fig. 49). Although the scour holes near piers 8 and 9 were somewhat wider in the scans of May 12-13 and July 8, 2009, they did not appear substantially deeper than the other scans (fig. 49). 


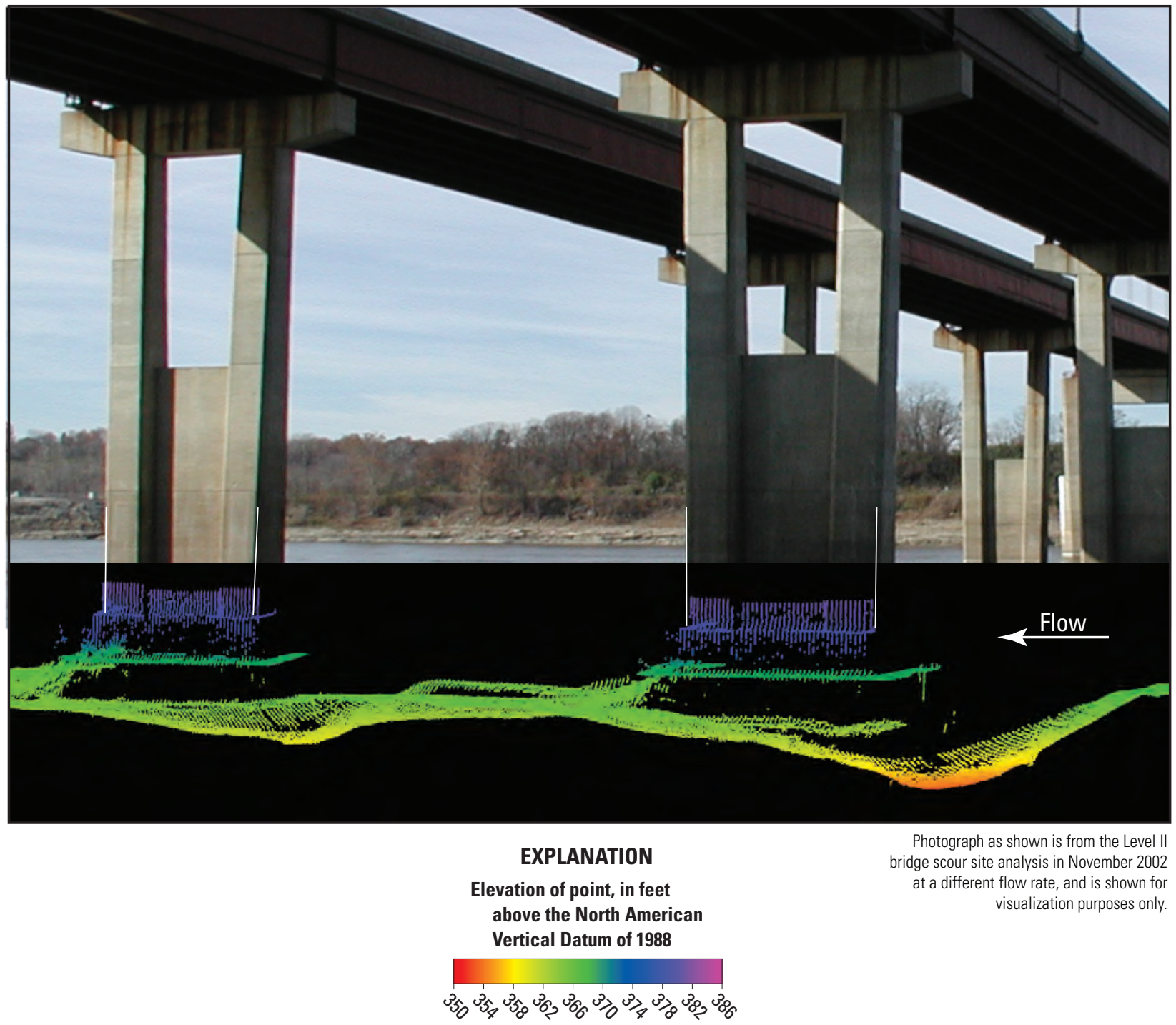

Figure 45. Point cloud visualization of the channel bed and left (east) side of main channel pier 9 of structures A4936 and A1850 on Interstate 255 over the Mississippi River near St. Louis, Missouri. 


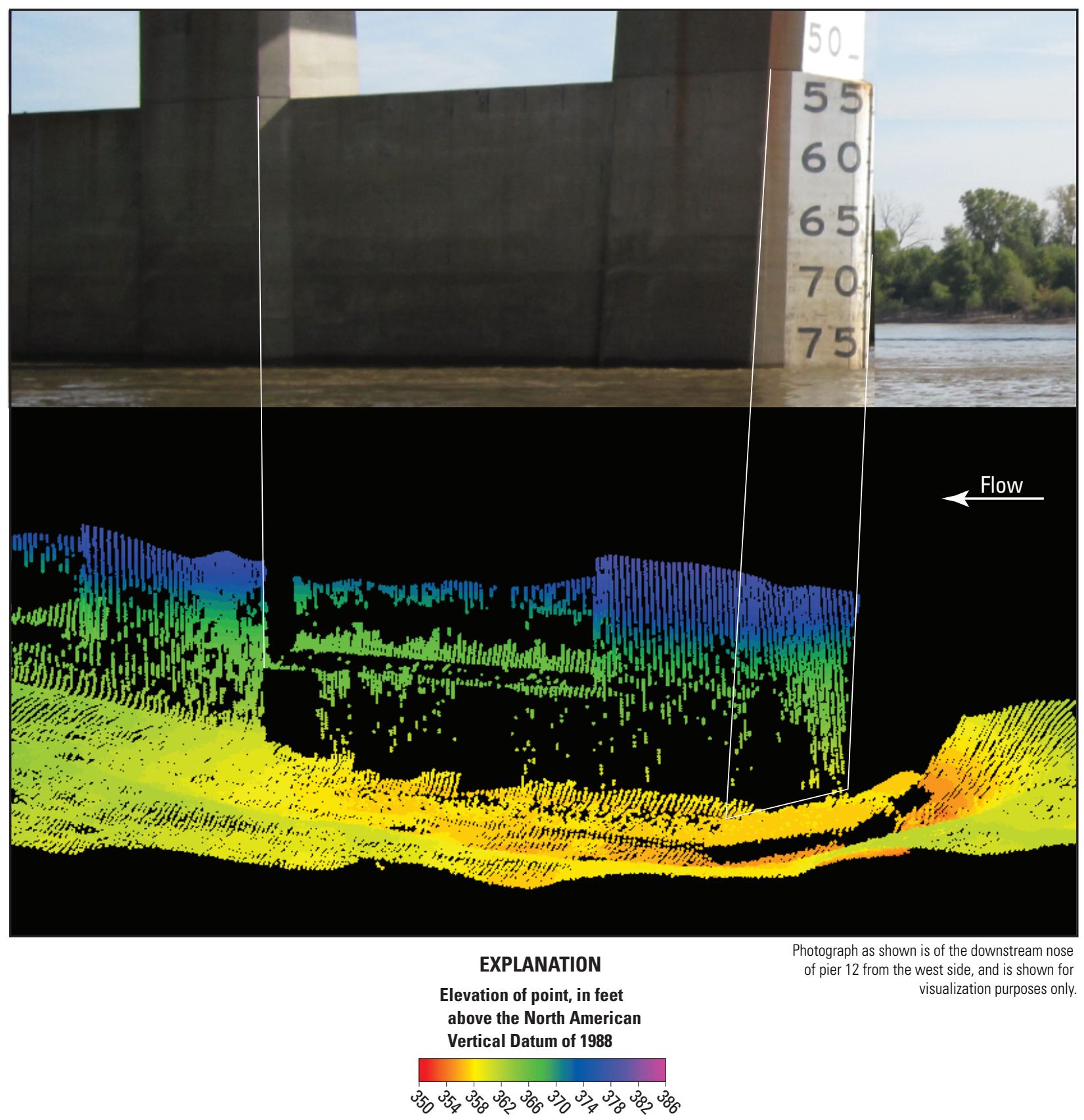

Figure 46. Point cloud visualization of the channel bed and left (east) side of main channel pier 12 of structures A4936 and A1850 on Interstate 255 over the Mississippi River near St. Louis, Missouri. 


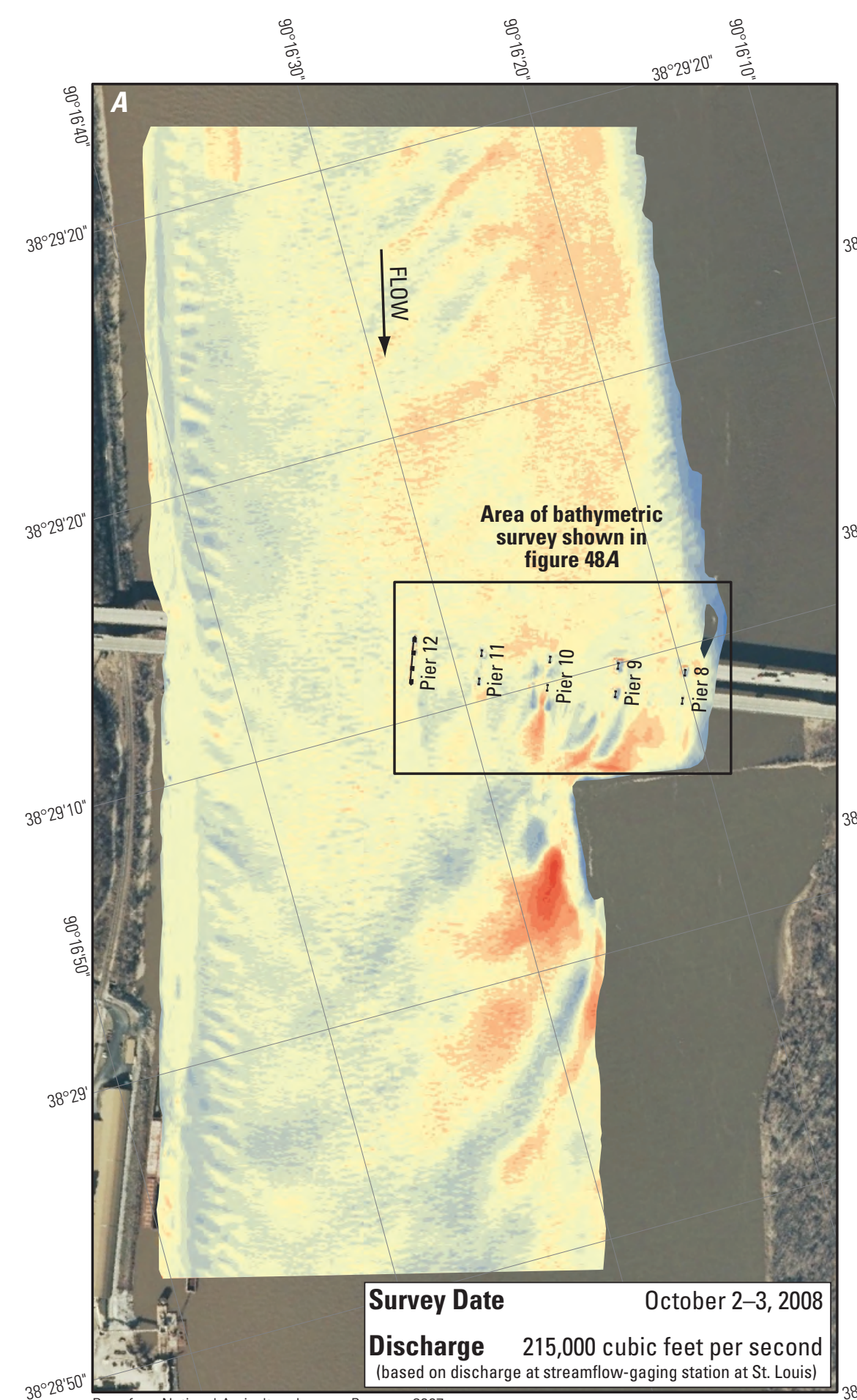

Discharge 215,000 cubic feet per second
(based on discharge at streamflow-gaging station at St towis)

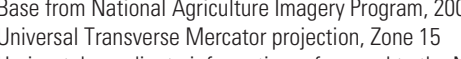

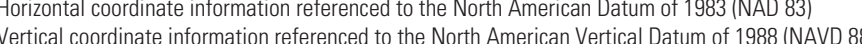

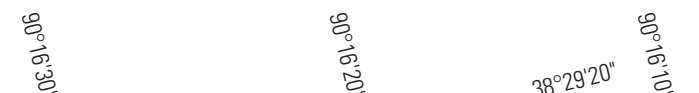

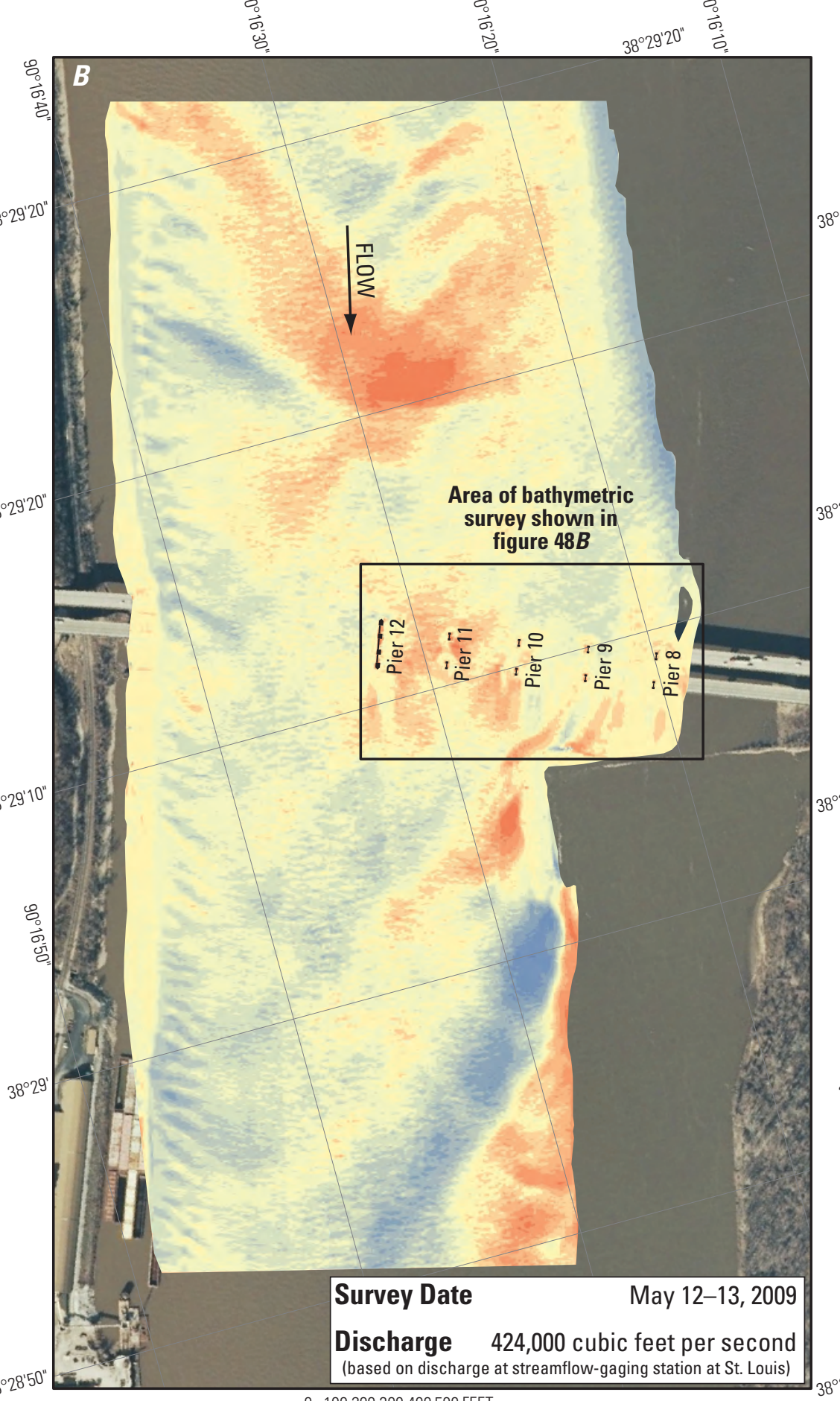

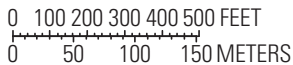

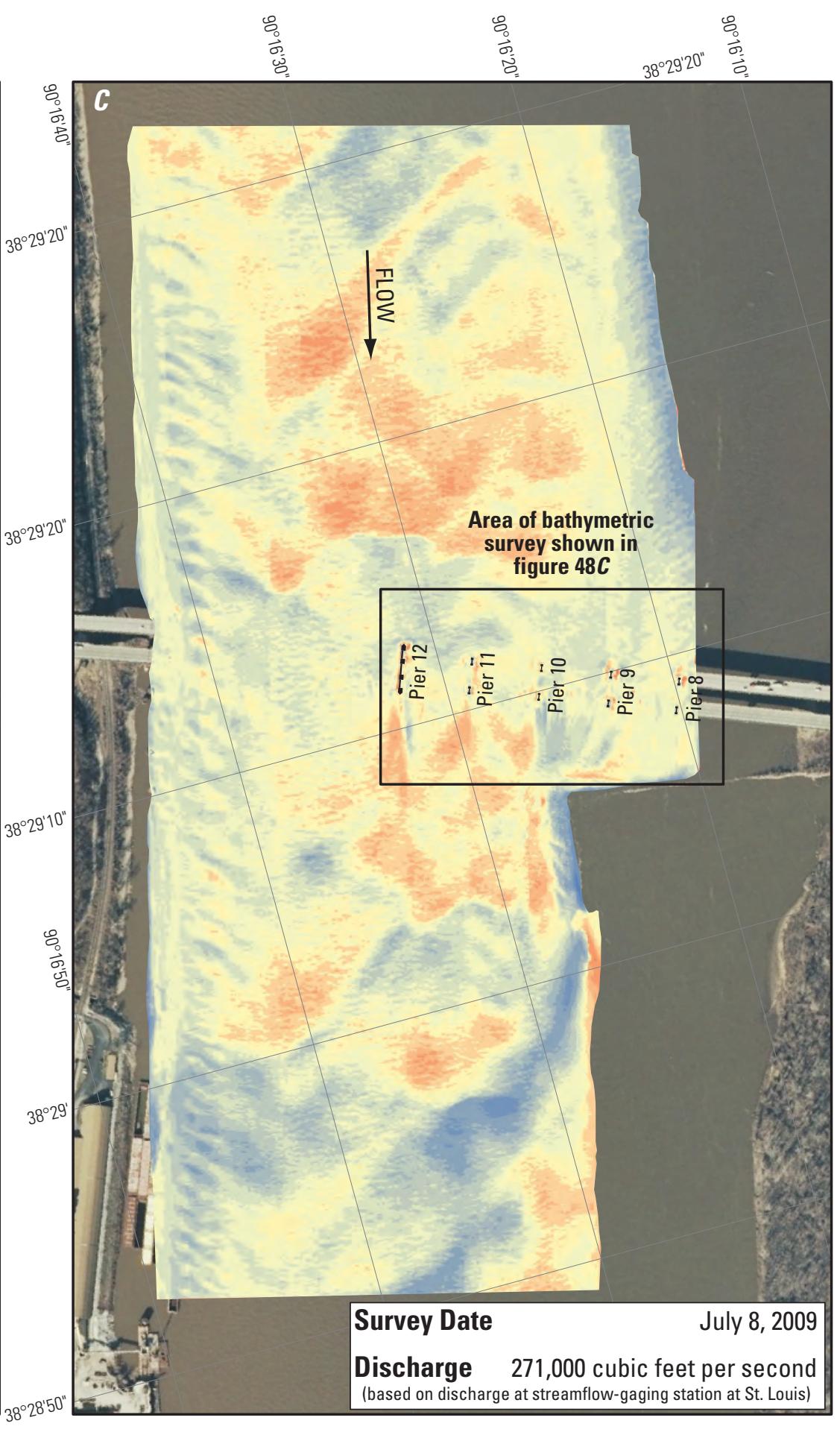

EXPLANATION

Change in channel-bed

30

20
15
10
10

10
-7
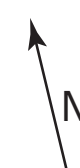

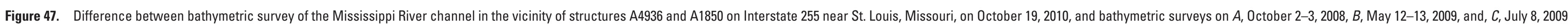




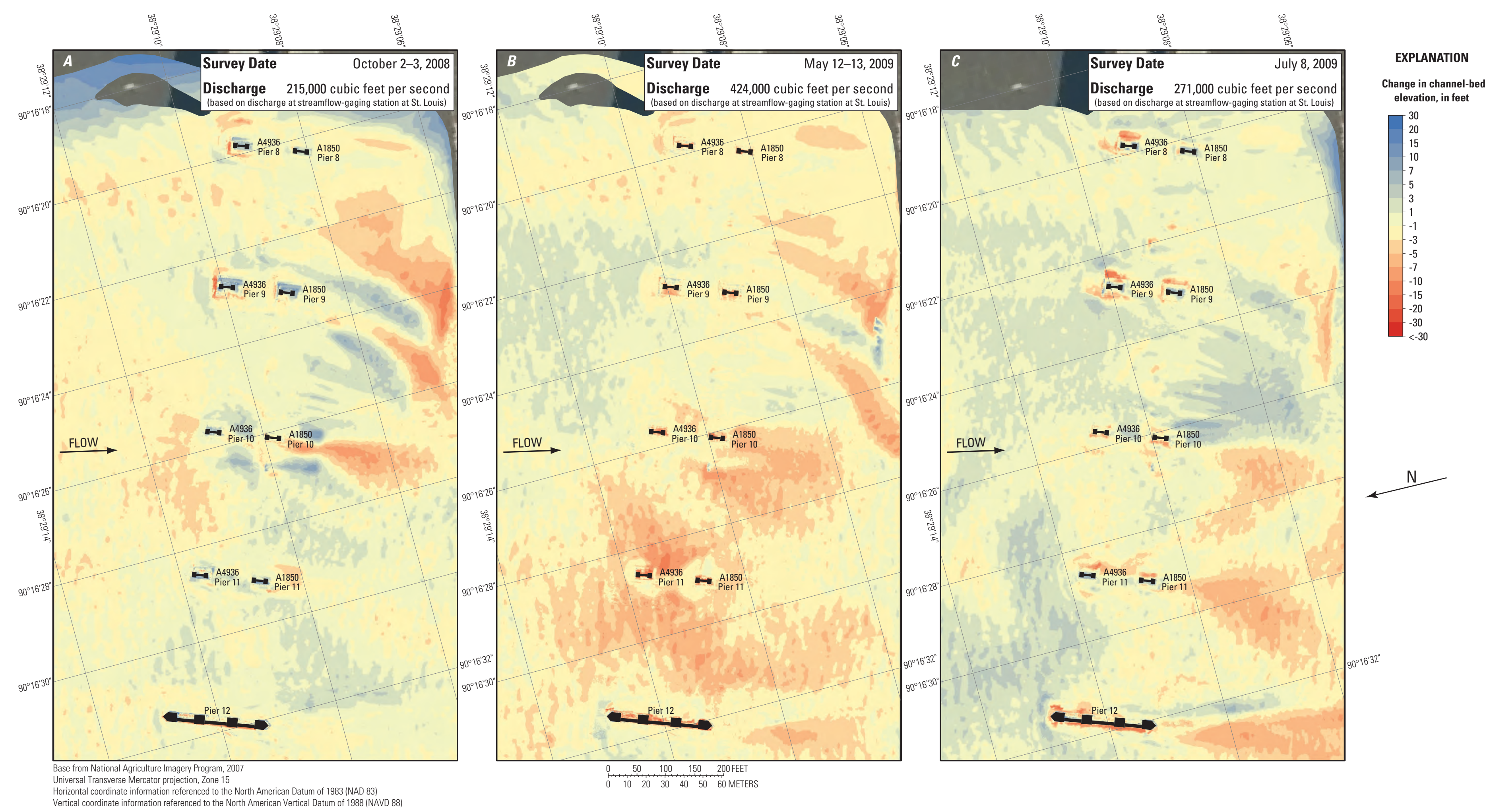

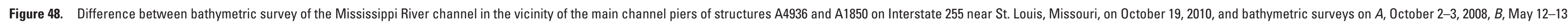
2009, and, C, July 8, 2009. 

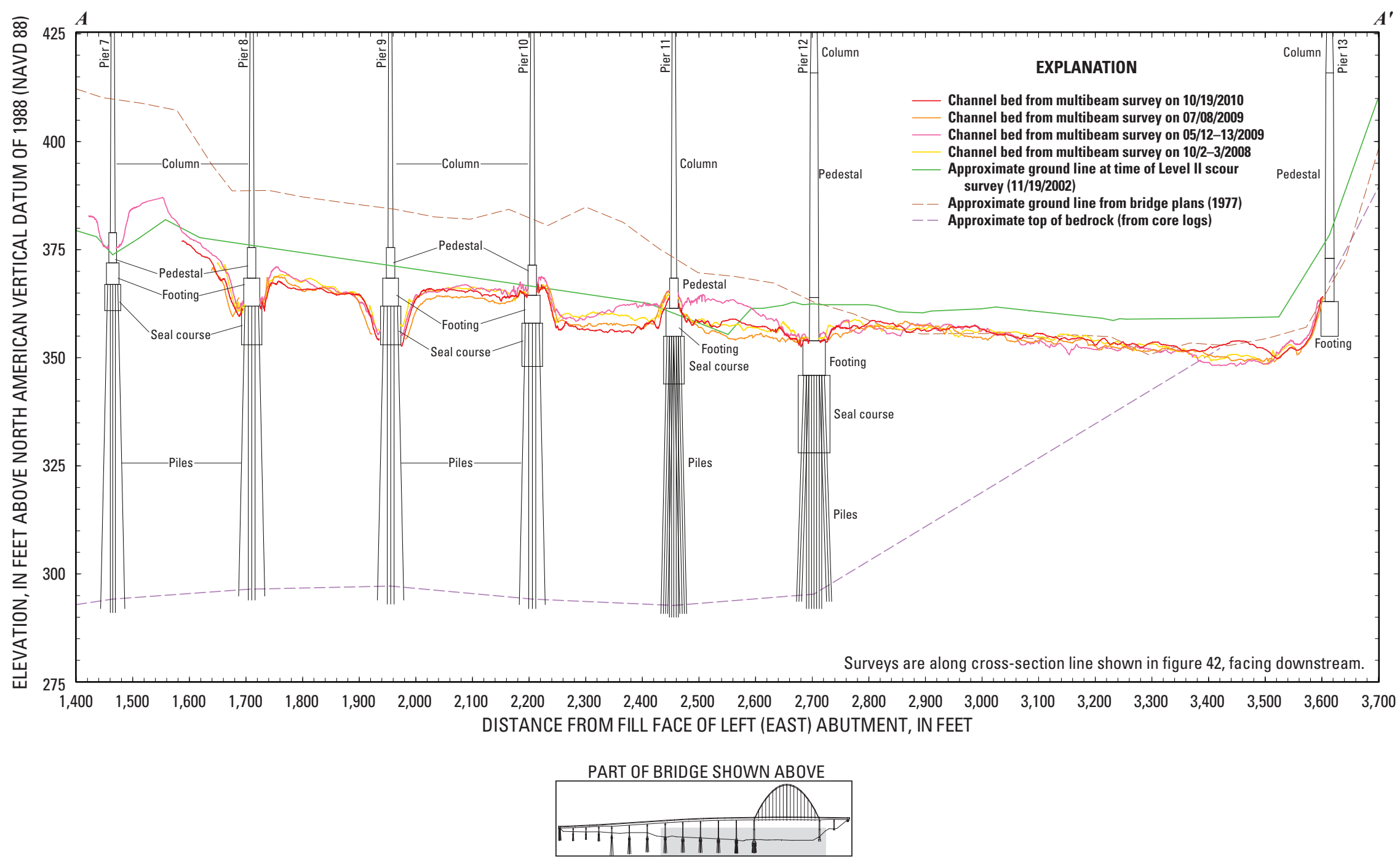

Figure 49. Key features, substructural and superstructural details, and surveyed channel bed along the upstream face of upstream structure A4936 on Interstate 255 over the Mississippi River near St. Louis, Missouri, from surveys on different dates. 


\section{General Findings and Implications}

Several of the findings at each surveyed bridge were common to all of the bridges, and some findings only appear when the surveys are examined as a set. These general findings are of benefit in the assessment of scour at the surveyed bridges, as well as other bridges in the vicinity or in similar settings.

\section{Shape of Scour Holes}

Generally, every pier in the main channel area for which bathymetry could be obtained had some sort of scour hole, except those on banks or embedded in rock dikes. A longitudinal profile was drawn upstream from the nose of each pier with a well-defined scour hole (figs. 50-53), and the approximate frontal slope (computed as horizontal distance over vertical distance, or run over rise) was determined for each hole (tables 6,7 ). The frontal slope was not determined for piers with poorly defined scour holes; however, the frontal slope was determined for scour holes near the various railroad bridge piers surveyed, because they often were more welldefined and deeper than the scour holes at the nearby MoDOT structure (fig. 53).

The approximate frontal slope (defined herein as run over rise for relatability to highway embankment slopes) of the well-defined scour holes ranged from 1.70 to 2.94 (fig. 53; tables 6, 7); however, the holes with the largest slope valuesor the shallowest slopes-[2.42 at structure A4557 Eastbound pier 3C (figs. 24, 51E; table 6), 2.72 at structure A1850 pier 9 (figs. 43, 52F; table 7), and 2.94 at the Wabash Railroad Bridge right pier (figs. 24, 53B)] are in lower velocity areas of the channel and may be affected by submerged objects in or near the scour hole. Submerged objects and rafts can cause the scour hole to enlarge by creating a wider obstruction to the flow, such as at structure A3292 pier 15 (fig. 18), and is believed to be part of the cause of the wide, shallow scour hole observed at structure A4017 pier 4 (figs. 6, 50A). If the three shallow slope values are not included, the frontal slopes ranged from 1.70 to 2.05 , with a mean value of 1.85 . Richardson and Davis (2001) noted that the side slope of a scour hole in cohesionless sand in air could range from 1.0 to 1.8 depending on the composition of the bed material and its dry angle of repose, and suggest using a value of 2.0 for design purposes to account for the wet angle of repose. The slope values determined in the St. Louis area generally are similar to the values noted in Richardson and Davis (2001). In the previous study in the Kansas City area, Huizinga (2010) stated "the slope values determined in the Kansas City area [(ranging from 1.77 to 2.49)] are somewhat greater than the range of values noted in Richardson and Davis (2001)," without making the distinction between the dry and wet angle of repose of cohesionless sand. When the wet angle of repose is considered, the slope values determined for scour holes in the Kansas City area are similar to those noted in Richardson and Davis (2001), as well as those determined for scour holes in the St. Louis area, with the exception of two larger slope values at sites affected by adjacent piers (Huizinga, 2010).

In the previous study in the Kansas City area (Huizinga, 2010), the movement of bed material affected the bathymetric data and the shape of the scour holes at several of the bridges, such that several of the scour holes displayed subtle "steps" and waves along the sides of the holes and in the longitudinal profiles. Several of the St. Louis area bridges also displayed similar but more subtle "steps" in the longitudinal profiles (figs. 50A, 50E, 51C, 51E, 52G, 53B, 53C); however, the waves along the sides of the holes are not present for the St. Louis area bridges, possibly because of the non-flood flow conditions during the time of the St. Louis area surveys. The non-flood flow conditions would result in less dynamic movement of bed material; subsequently, the scour holes would be less likely to have lateral or longitudinal sand input.

Unlike in the previous study in the Kansas City area (Huizinga, 2010), only a few of the bridges surveyed had piers that were skewed to approach flow (structures A4017 and J1000 on U.S. Highway 40 over the Missouri River, and structures A4936 and A1850 on Interstate 255 over the Mississippi River were exceptions), resulting in asymmetric scour holes at those bridges. The scour hole typically was deeper and longer on the side of the pier with impinging flow, with some amount of deposition on the leeward side (figs. 5, 8, 11, 43). Nevertheless, the various spur dikes and L-head dikes throughout the surveyed areas often created a flow field near the surveyed bridges that caused a unique type of skewed flow, also resulting in asymmetric scour holes near certain piers that were not skewed to the primary approach flow direction. At structure A5585, the spur dike on the right bank upstream from piers 6 and 7 (fig. 13) deflected flow to the left towards the center of the channel, which caused an unusual flow field in the vicinity of the piers and resulted in asymmetric scour holes at all of the piers (fig. 14). The scour holes were longer and deeper on the left sides of piers 5 and 6, with deposition on the right sides, whereas the opposite is true at pier 7 (fig. 14). At structure A4557, the spur dike on the right bank under the bridge between piers 3C and 4C (fig. 23) deflected flow to the left towards the center of the channel, creating a flow field that caused deposition on the left sides of pier 3C, and yet also caused the scour holes to be longer and deeper on the left sides of pier 3C (fig. 24). At structure A3047, the spur dike on the right bank upstream from the railroad bridge and structure A3047 deflected flow to the left towards the channel (fig. 28), and the subsequent expansion of flow to the right downstream from the spur dike caused the scour holes to be longer and deeper on the left side of the right main channel piers of the railroad bridge and structure A3047, with deposition on the right sides (fig. 32). The large L-head dike downstream from structures A4936 and A1850 (fig. 42) deflected flow to the right into the main channel, which resulted in curved ridges and valleys in the channel bed trailing away downstream from the piers and submerged features under the bridge (fig. 43). 

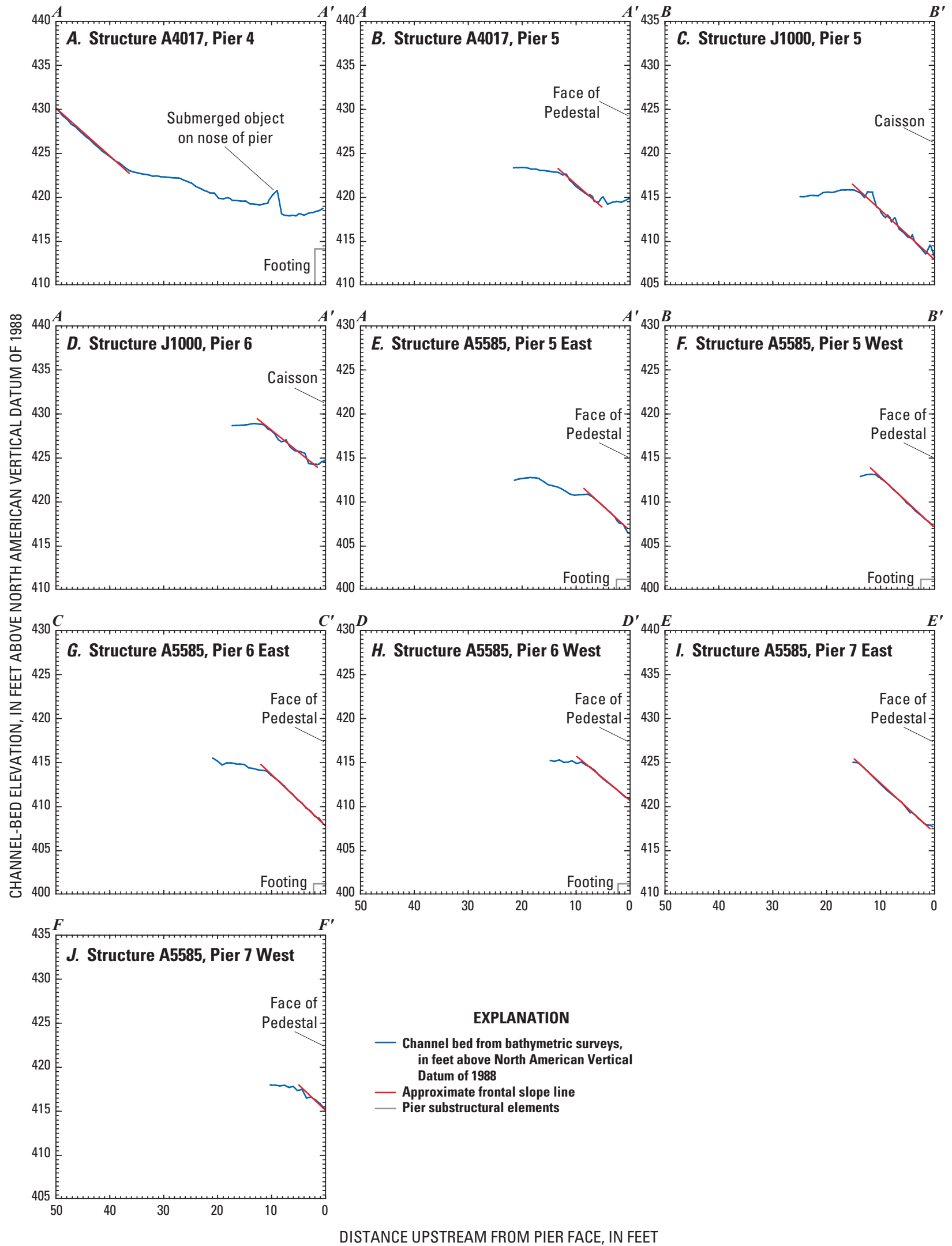

Figure 50. Longitudinal profiles upstream from piers at structures A4017, J1000, and A5585 on the Missouri River near St. Louis, Missouri. 


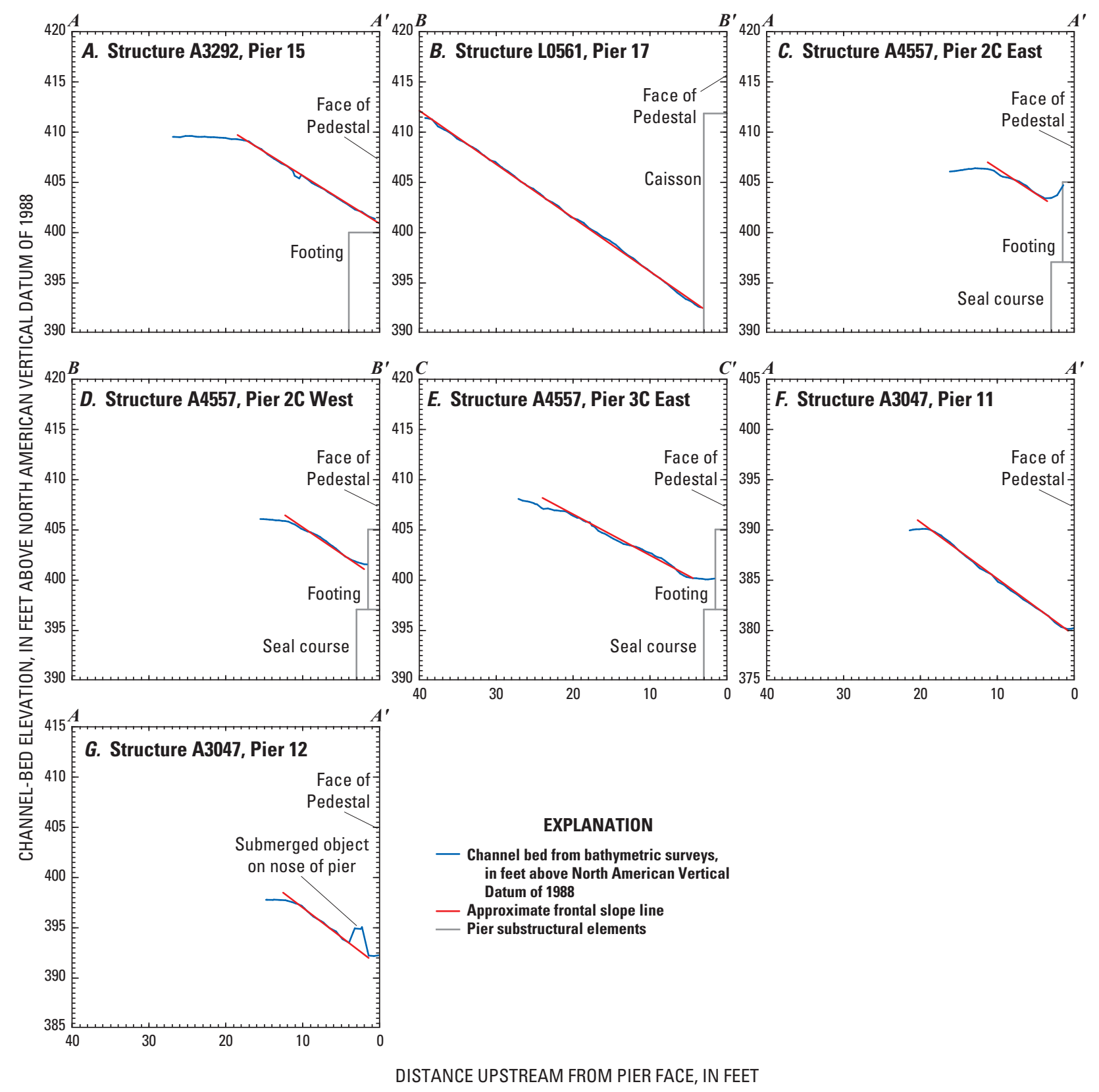

Figure 51. Longitudinal profiles upstream from piers at structures A3292, L0561, A4557, and A3047 on the Missouri River near St. Louis, Missouri. 


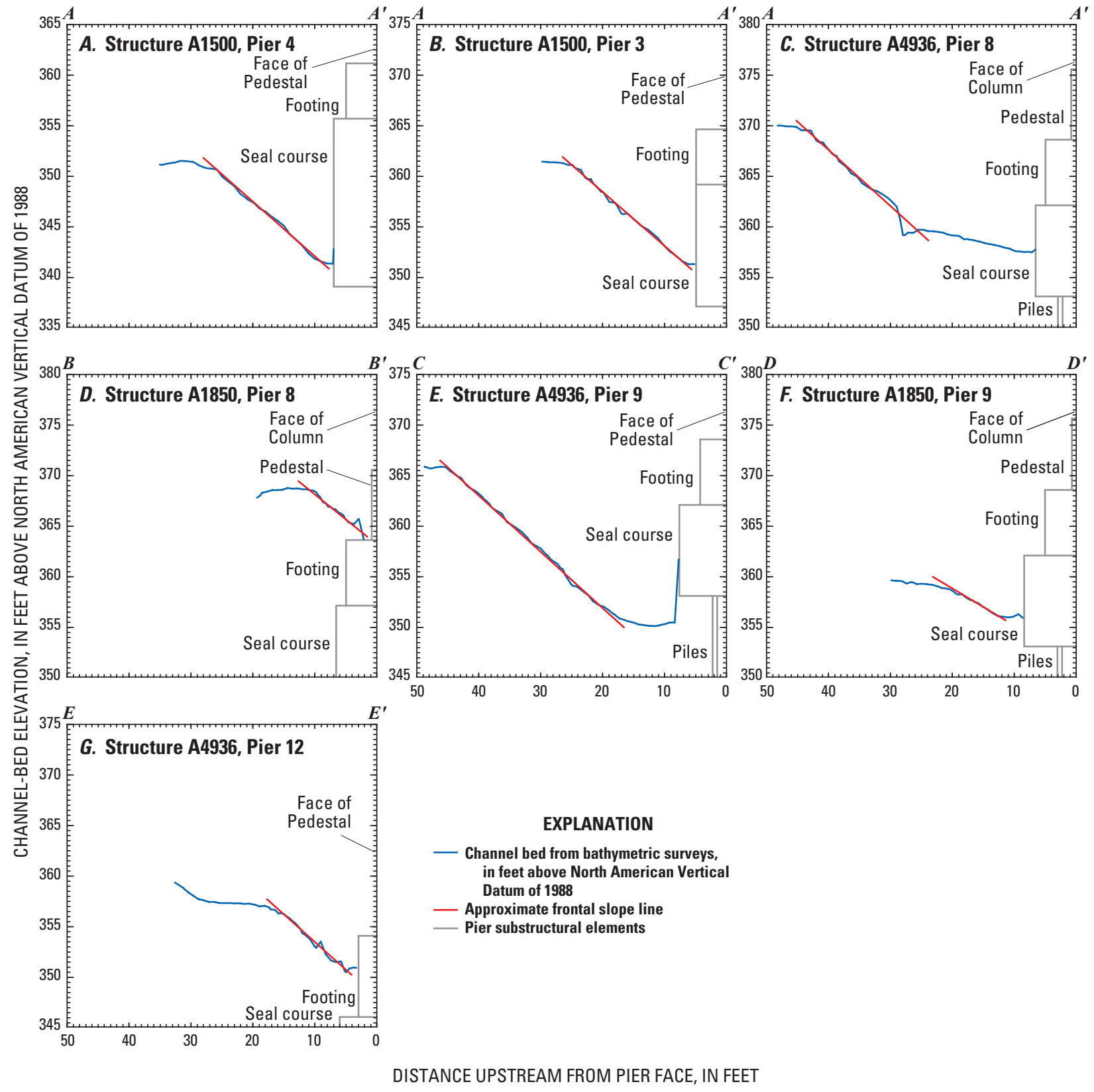

Figure 52. Longitudinal profiles upstream from piers at structures A1500, A4936, and A1850 on the Mississippi River near St. Louis, Missouri. 

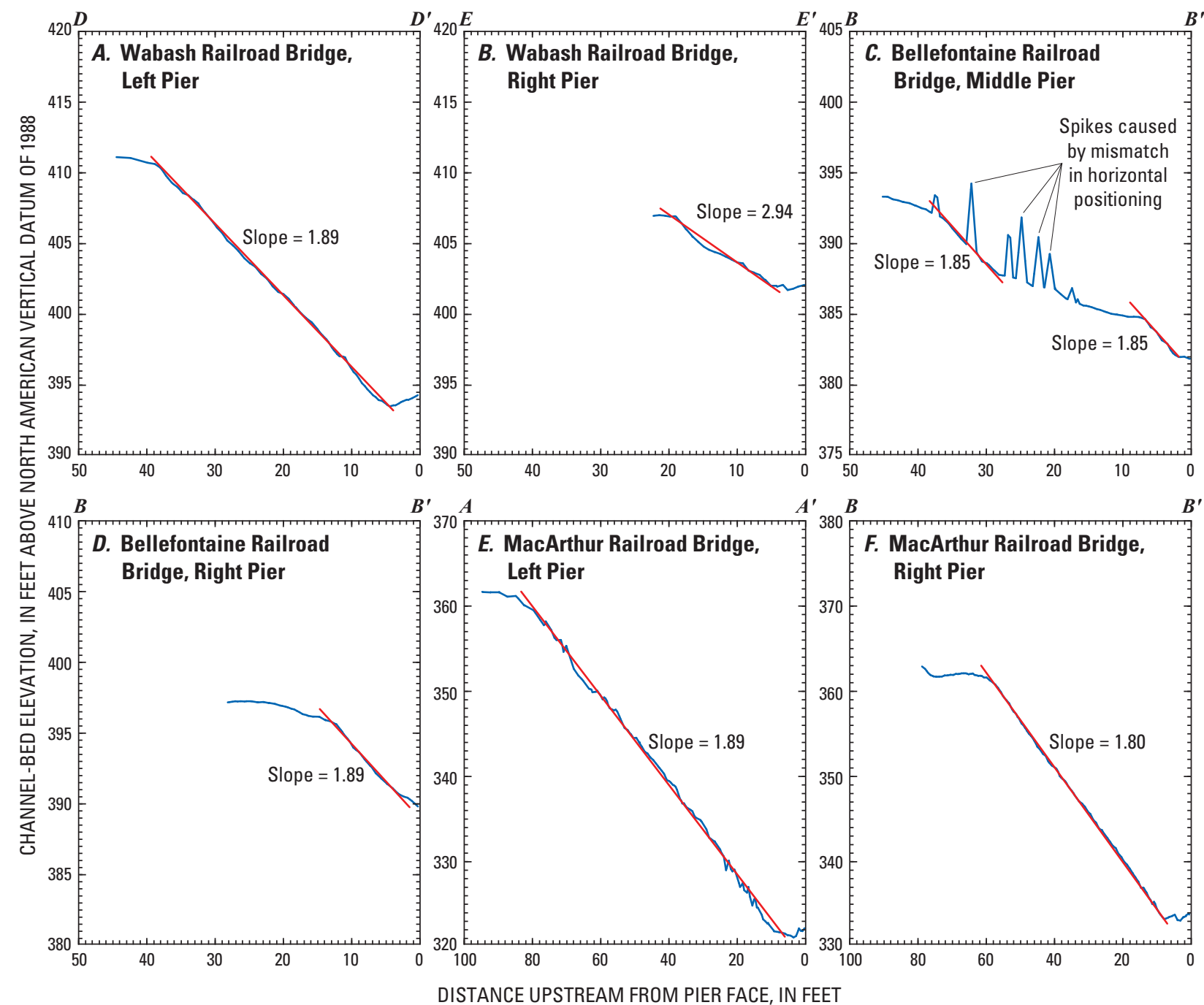

DISTANCE UPSTREAM FROM PIER FACE, IN FEET

\section{EXPLANATION}

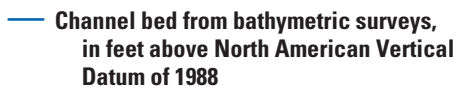

— Approximate frontal slope line

Figure 53. Longitudinal profiles upstream from railroad bridge piers near structures A4557, A3047, and A1500 on the Missouri and Mississippi Rivers near St. Louis, Missouri. 


\section{Long-Term Channel-Bed Changes}

Almost all of the bridges had a lower channel-bed elevation during the 2010 surveys than when the bridges had been built for a substantial part of the channel cross section, which indicates a general decrease in the channel-bed elevation on the Missouri and Mississippi Rivers with time. Although there was essentially no change between the surveyed channel bed and the ground line from bridge plans at the newest highway crossing (dual bridge structure A5585), the channel bed at the remaining surveyed bridges was lower than the ground line from bridge plans, ranging from about $5 \mathrm{ft}$ to nearly $16 \mathrm{ft}$. The largest differences occurred at two older bridges (structures $\mathrm{J} 1000$ and L0561), but a difference of nearly $8 \mathrm{ft}$ was observed at another new highway crossing (dual bridge structure A4557), and indicates a lowering of the channel-bed elevations at a maximum rate of $0.5 \mathrm{ft}$ per year.

Researchers have stated that water stage appears to be decreasing with time on the Mississippi River for discharges less than flood stage (Brauer, 2009; Huizinga, 2009), and Huizinga (2009) further stated that this likely is resulting from a combination of channel deepening caused by rock spur dikes in the channel, a decrease in the overall sediment load on the Mississippi and Missouri Rivers caused by upstream reservoirs, and declines in sediment transport in Missouri River tributaries (Meade and Moody, 2010). A decrease in the stage with time for discharges below flood stage was shown for the streamgages on the Mississippi River at St. Louis, Missouri, and Chester, Illinois (Huizinga, 2009), which implies a decrease in the channel-bed elevations with time; however, the decrease is not as large as was observed for the Kansas City streamgage, nor does it appear to be accelerating with time as was observed for the Kansas City streamgage (Huizinga, 2009, 2010).

Huizinga (2009) also computed an average channel-bed elevation for the Mississippi River at St. Louis by dividing the total measured area by the measured top width from discharge measurements, and subtracting this from the water-surface elevation for the measurement. This analysis showed the average channel-bed elevation gradually has decreased with time at St. Louis for flows within the channel banks, with large temporary fluctuations in the channel-bed elevation caused by large flood events. The adjustment of the channel to a modified sediment regime and channel control structures, and the resulting long-term trend in channel-bed elevation could explain the lower channel bed at the time of the bathymetric surveys as compared to the Level II surveys or at the time of bridge construction of the various bridges.

\section{Effects of Moderate Flooding During Surveys}

Richardson and Davis (2001) separate long-term aggradation and degradation of a channel from the contraction and local scour that occurs at a bridge site during floods. Contraction scour is the general change in the channel-bed elevation across a bridge opening resulting from the passage of a flood through a constriction. Local scour is the localized erosion of material caused by flow vortex action that forms near bridge piers and abutments. Although all of the scour processes (longterm, contraction, and local scour) continually are at work, contraction and local scour generally are cyclic, resulting in a decrease and increase of the channel-bed elevation during the passage of a flood.

Flood durations on the Missouri and Mississippi Rivers near St. Louis generally are measured in weeks and months because of the large upstream contributing drainage area. Although the surveyed local scour effects at the bridges in the St. Louis area appear to be well-established and apparently stable, the Missouri and Mississippi Rivers were in low to moderate flow conditions during the surveying effort, slowly receding from the summer flood season, which would have an effect on the local scour at the bridge sites. Huizinga (2009) observed that the streamgages on the Mississippi River at St. Louis, Missouri, and Chester, Illinois, routinely experience channel degradation and infilling during the passage of a flood. During the 1993 flood, the measurement section at the St. Louis streamgage indicated as much as $24 \mathrm{ft}$ of fluctuation in the channel thalweg during the flood, but the post-flood channel bed configuration was similar to the pre-flood configuration. The measurement section from the peak discharge on July 31, 1993, from Huizinga (2009) is shown in figure 36 , along with the surveyed channel for the Level II study in August 2010 and from this study, and clearly demonstrates the dynamic nature of the channel bed in this reach of river. The measurement section at the Chester streamgage indicated steady degradation of more than $18 \mathrm{ft}$ in the channel thalweg up to the peak of the flood in 1993, and steady aggradation after the peak, with a post-flood configuration within about $8 \mathrm{ft}$ of the pre-flood configuration (Huizinga, 2009). Therefore, the scour holes observed at the bridges in the St. Louis area likely are transient, and may have been experiencing infilling upon recession of the summer flood conditions. If the bridges were to be surveyed at high-flow conditions, the scour holes could be larger.

\section{Summary and Conclusions}

Bathymetric surveys were conducted on the Missouri and Mississippi Rivers in the vicinity of 12 highway bridges at 7 crossings near St. Louis, Missouri, by the U.S. Geological Survey in cooperation with the Missouri Department of Transportation. A multibeam echo sounder mapping system was used to obtain channel-bed elevations for areas ranging from 3,280 to 4,590 feet long and extending across the active main channel of the Missouri and Mississippi Rivers. The active channel at a given site generally was delimited by L-head dikes or the channel bank on one side of the channel to similar features or shallows near spur dikes on the opposite side. These bathymetric scans provide a snapshot of the channel conditions at the 
time of the surveys and provide characteristics of scour holes that may be useful in the development of predictive guidelines or equations for scour holes. These data also may be used by the Missouri Department of Transportation to assess the bridges for stability and integrity issues with respect to bridge scour.

At all of the surveyed bridges, medium and small dunes and ripples were detected in the channel, and large dune features were detected at structures A5585 and A3047 on the Missouri River and at all three structures on the Mississippi River. Substantial rock outcrops were evident at all but two of the sites, generally along one of the banks.

Bathymetric data were collected around every pier that was in water, except those at the edge of water or in extremely shallow water, and one pier at structure A3292 on Interstate 70, which was surrounded by a large debris raft. Scour holes were present at most piers for which bathymetry could be obtained, except at piers on channel banks or those near or embedded in rock dikes. Two sets of piers at structures A4936 and A1850 on Interstate 255 over the Mississippi River appeared to be surrounded by scour-resistant material, and did not have well-defined scour holes. The other scour holes observed at the surveyed bridges were examined with respect to frontal slope and shape. The scour holes near railroad bridges in the vicinity of the highway bridges also were examined. Although exposure of parts of substructural support elements was observed at several piers, the exposure likely can be considered minimal compared to the overall substructure that remains buried at these piers.

At piers with well-defined scour holes, the frontal slopes of the holes ranged from 1.70 to 2.94 feet per foot (taken as run over rise), which were similar to recommended values in the literature and those obtained in a similar study of bridges in the Kansas City area in 2010. Unlike the study in the Kansas City area, however, the shape of the scour holes was not substantially affected by the movement of dune features into and around the holes, although a few of the scour holes displayed subtle steps in their longitudinal profiles indicative of sand waves moving into the hole.

Although most of the structures had piers that were not skewed to primary approach flow, spur dikes near several of the piers caused localized flow disturbances. The piers near the spur dikes had scour holes that displayed characteristics of skewed approach flow, generally with deposition on the leeward side of the pier and greater depth on the side of the pier with impinging flow.

The channel bed at nearly all of the surveyed bridges was lower than the ground line from bridge plans at the time of construction, ranging from almost no change at one newer bridge to nearly 16 feet at two older bridges, which indicates a lowering of the channel-bed elevations with time. This finding is consistent with similar findings from bathymetric surveys on the Missouri River at Kansas City, Missouri, and with findings of other similar research on the Mississippi River. However, a recent Level II bridge scour analysis of structure A1500 on Interstate 55 over the Mississippi River indicates the dynamic nature of the channel bed at this site, which also is consistent with other research on the Mississippi River.

The Missouri and Mississippi Rivers were in low to moderate flow conditions at the time of the surveys, and the size and shape of the scour holes likely was affected by the conditions. It is likely that the scour holes would be larger during conditions of higher flow.

The bathymetry data at two of the surveyed sites display artifacts of horizontal positioning errors on adjacent survey lines obtained near the bridges at these sites. An analysis of the surveys indicated that over half of the bathymetric data have a total propagated error of less than 0.33 feet.

\section{References Cited}

Brauer, E.J., 2009, The limitations of using specific-gage analysis to analyze the effect of navigation structures on flood heights in the Middle Mississippi River: Permanent International Association of Navigation Congress, 2009 De Paepe-Williams Award Contest, 18 p.

Calder, B.R., and Mayer, L.A., 2003, Automatic processing of high-rate, high-density multi-beam echosounder data: Geochemistry, Geophysics, Geosystems, v. 4, p. 1,048.

Czuba, J.A., Best, J.L, Oberg, K.A., Parsons, D.R., Jackson, P.R., Garcia, M.H., and Ashmore, P., 2011, Bed morphology, flow structure, and sediment transport at the outlet of Lake Huron and in the Upper Saint Clair River: Journal of Great Lakes Research, v. 37, no. 3, p. 480-493.

Environmental Systems Research Institute, 2010, ArcGIS, accessed September, 2010, at URL http://www.esri.com/ software/arcgis/.

Huizinga, R.J., 2009, Examination of direct discharge measurement data and historic daily data for selected gages on the Middle Mississippi River, 1861-2008: U.S. Geological Survey Scientific Investigations Report 2009-5232, 60 p.

Huizinga, R.J., 2010, Bathymetric surveys at highway bridges crossing the Missouri River in Kansas City, Missouri, using a multibeam echo sounder, 2010: U.S. Geological Survey Scientific Investigations Report 2010-5207, 61 p.

Huizinga, R.J., Elliott, C.M., and Jacobson, R.B., 2010, Bathymetric and velocimetric survey and assessment of habitat for pallid sturgeon on the Mississippi River in the vicinity of the proposed Interstate 70 Bridge at St. Louis, Missouri: U.S. Geological Survey Scientific Investigations Report 2010-5017, 28 p.

Huizinga, R.J., and Rydlund, P.H., Jr., 2004, Potential-scour assessments and estimates of scour depth using different techniques at selected bridge sites in Missouri: U.S. Geological Survey Scientific Investigations Report 2004-5213, $42 \mathrm{p}$. 
HYPACK, Inc., 2009, HYPACK ${ }^{\circledR}$ Hydrographic survey software user's manual 1/09: Middletown, Conn., 1,394 p.

Lagasse, P.F., Shall, J.D., Johnson, F., Richardson, E.V., Richardson, J.R., and Chang, F., 1991, Stream stability at highway structures: U.S. Federal Highway Administration Publication FHWA-IP-90-014 Hydraulic Engineering Circular No. 20, 195 p.

Meade, R.H., and Moody, J.A., 2010, Causes for the decline in suspended-sediment discharge in the Mississippi River system, 1940-2007: Hydrological Processes v. 24, p. 35-49.

RESON, Inc., 2008, SeaBat ${ }^{\mathrm{TM}} 7125$ high-resolution multibeam echosounder system operator's manual, Version 6.01: Goleta, Calif., 100 p.

Richardson, E.V., and Davis, S.R., 2001, Evaluating scour at bridges ( $4^{\text {th }}$ ed.): U.S. Federal Highway Administration Publication FHWA NHI 01-001 Hydraulic Engineering Circular No. 18, 378 p.

Rydlund, P.H., Jr., 2009, Real-time river channel-bed monitoring at the Chariton and Mississippi Rivers in Missouri, 2007-09: U.S. Geological Survey Scientific Investigations Report 2009-5254, 27 p.
U.S. Army Corps of Engineers, 2004a, Upper Mississippi River System flow frequency study, Appendix E: U.S. Army Corps of Engineers, Rock Island, Illinois, accessed March, 2011, at URL http://www.mvr.usace.army.mil/pdw/pdf/ flowfrequency/Documents/FinalReport/default.asp.

U.S. Army Corps of Engineers, 2004b, Upper Mississippi River System flow frequency study, Appendix D: U.S. Army Corps of Engineers, Rock Island, Illinois, accessed March, 2011, at URL http://www.mvr.usace.army.mil/pdw/ pdf/flowfrequency/Documents/FinalReport/default.asp.

U.S. Army Corps of Engineers, 2004c, Engineering and design-Hydrographic surveying: Washington D.C., U.S. Army Corps of Engineers, manual no. EM 1110-2-1003, $560 \mathrm{p}$.

U.S. Geological Survey, 2003, User's manual for the National Water Information System of the U.S. Geological Survey: Automated Data Processing System (ADAPS): U.S. Geological Survey Open-File Report 2003-123, 413 p., accessed September, 2010, at URL http://pubs.usgs.gov/ of $/ 2003 /$ ofr $03123 /$.

U.S. Geological Survey, 2011, National Water Information System: U.S. Geological Survey database, accessed March, 2011, at URL http://waterdata.usgs.gov/nwis/. 
Publishing support provided by:

Rolla Publishing Service Center

For more information concerning this publication, contact:

Director, USGS Missouri Water Science Center

1400 Independence Road

Rolla, M0 65401

(573) 308-3667

Or visit the Missouri Water Science Center Web site at: http://mo.water.usgs.gov/ 
Back cover. Point cloud visualization of the channel bed and right (west) side of the left main channel pier (pier 4) of structure A1500 on Interstate 55 over the Mississippi River near St. Louis, Missouri. 


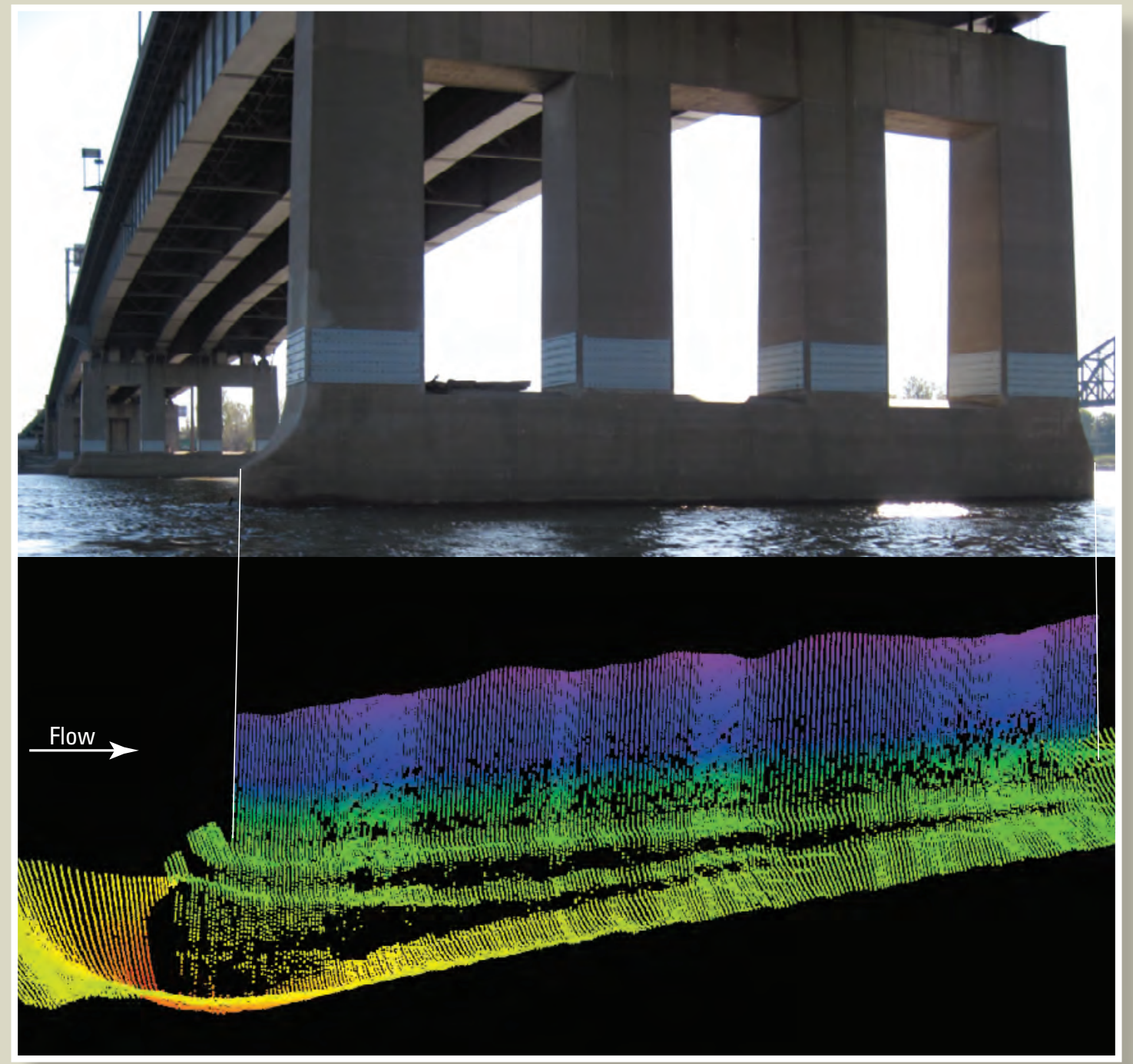

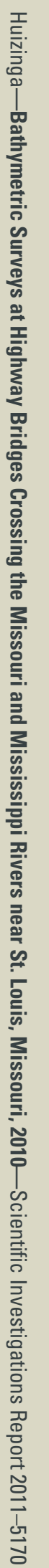

